\title{
The Biodegradation of Ionic Liquids - the View from a Chemical Structure Perspective
}

\author{
Stefan Stolte ${ }^{1,2^{*}}$, Stephanie Steudte $^{3}$, Amaya Igartua $^{2}$ and Piotr Stepnowski ${ }^{3}$ \\ ${ }^{1}$ Department Sustainable Chemistry, Centre for Environmental Research and Sustainable Technology, University of Bremen, \\ Leobener Str. UFT, 28359 Bremen, Germany. \\ ${ }^{2}$ Tribology Unit, Fundación Tekniker, Otaola 20, 20600 Eibar, Spain \\ ${ }^{3}$ Department of Environmental Analysis, Faculty of Chemistry, University of Gdańsk, Sobieskiego 18, 0-952 Gdańsk, Poland
}

\begin{abstract}
The idea of green or sustainable chemistry is to develop highly efficient technical processes and applications using chemicals with a reduced or zero hazard potential for man and the environment. This approach is perfectly applicable to ionic liquids (ILs). These substances have potential applications in different fields (economic interests), and so far millions of possible structures have been designed, thousands of which have actually been produced, providing a broad base for the structural design of ILs with optimal technological properties and at the same time posing a reduced hazard to humans and the environment. In parallel with the rapidly growing (eco) toxicological knowledge regarding ILs, the available data regarding their biodegradability are also increasing. The following sections introduce the reader to biodegradation test procedures and present an overview of existing aerobic and anaerobic biodegradation data concerning ILs. Besides pure biodegradation kinetics, this discussion covers data on biological degradation products (metabolites) and abiotic degradation processes. Throughout this review special emphasis will be placed on structure-biodegradability relationships and the question whether the $10^{\text {th }}$ principle of Green Chemistry, namely, Design chemicals and products to degrade after use: design chemical products to break down to innocuous substances after use so that they do not accumulate in the environment, is or is not fulfilled for some IL structures. The discussion of this data should help to improve the future design of inherently safer ILs, thereby reducing the risks they may pose to humans and the environment.
\end{abstract}

Key Words: Biodegradation, metabolization, organic cations, structure-biodegradability relationships, sustainable design, weakly coordinating anions.

\section{INTRODUCTION}

In recent years ionic liquids (ILs) have attracted great interest because of their beneficial and tunable physico-chemical properties, for instance, excellent thermal and electrochemical stability, low vapor pressure, wide range of fluidity and favorable solvation properties. Several applications and potential implementations using ILs have been described in, e.g., cellulose dissolution [1], aluminum plating [2], gas compression [3], gas handling [4], lithium-ion batteries [5], dye-sensitized solar cells [6] and as paint additives [7]. The recent applications of ILs in the chemical industry are excellently summarized by Plechkova and Seddon [8]. This critical review mentions several companies that are using ILs from smallscale to pilot plant to large-scale industrial applications. Thus, ILs are no longer confined to academic ivory towers: they are already present in commercial products and processes. But this comes with the increased probability that ILs will be continuously released into the biosphere, for example, as process effluents or consumer products, or in larger amounts as accidental spills.

The chemical industry bears collective responsibility for its products in order to prevent the short- and long-term adverse effects of these substances on man and the environment. In recent decades the extensive production, use and release of man-made chemicals has resulted in serious environmental problems such as climate change, stratospheric ozone depletion, eutrophication, water pollu-

*Address correspondence to this author at the Department Sustainable Chemistry, Centre for Environmental Research and Sustainable Technology, University of Bremen, Leobener Str. UFT, 28359 Bremen, Germany; Tel: --------------; Fax: --------------; E-mail: stefan.stolte@ uni-bremen.de tion and acidification, and loss of biodiversity. In addition, certain chemicals have been responsible for disasters, like the dioxin pollution accident in Seveso (Italy) in 1976 or the poisoning of workers in Bhopal (India) with the highly toxic chemical methylisocyanate in 1984. All these disasters, whether chemical accidents with a primarily local impact (e.g. the Bhopal accident) or fugitive emissions of chemicals (e.g. chlorofluorocarbons) with adverse effects on the global environment, have raised public awareness of the potential hazards and risks arising from chemical substances. As a consequence the regulation of chemicals has become more stringent. Furthermore, efforts are being made to develop strategies to combat environmental and health problems due to chemicals like the "Responsible Care" initiative from the chemical industry to improve health, safety and the environmental performance of chemical products and processes. The chemical philosophy of encouraging the design of products and processes that reduce or eliminate the use and generation of hazardous substances was first defined and described by Paul Anastas and John C. Warner in 1998 in their 12 Principles of Green Chemistry [9].

The idea of green or sustainable chemistry is perfectly applicable to the "newly arising" substance class of ILs. Without doubt, they are potentially applicable in different fields (economic interests), millions of possible structures have already been designed, thousands of which have actually been produced, providing a broad base for the structural design of ILs with optimized technological properties and concomitantly a reduced hazard for humans and the environment. Several producers, developers and users of ILs are highly focused on the development of environmentally benign structures in the early stage of research - moving from the former "end of pipe" solutions to a proactive approach and hence to a fu- 
ture paradigm of environmental protection. The image of ILs has changed, especially during the last few years. In the beginning, the whole class of these substances was glibly described as "green" and "environmentally benign". Those statements were justified, given the negligible vapor pressure of ILs, which meant that they were non-flammable, non-explosive and produced minimal air emissions. Indeed, this pronounced advantage for operational safety does include a large "green" potential, but without a sound knowledge of the (eco)toxicological behavior - the hazard potential - of ILs, there can be no justification for such a classification. Moreover, in view of the vast structural diversity of ILs, general statements like "ILs are green", "ILs are toxic" or "ILs are persistent" are to be avoided. These suggestive generalizations have been counterproductive to the development of products and processes containing ILs. In the meantime, however, a paradigm shift has taken place following the expansion in knowledge of ILs produced by the growing number of studies analyzing the hazard potential of many such liquids in different biological test systems [10-17]. Thus, we now know that some ILs have a low and others a high hazard potential [13]. As expected, the ecotoxicity of ILs depends strongly on their molecular structure.

However, apart from a low (eco)toxicity, current environmental legislation makes insistent demands for non-persistent chemicals. For chemicals to be described as "sustainable" or "green", complete and rapid biotic and/or abiotic degradation is a crucial requirement, in accordance with Paul Anastas' and John Warner's $10^{\text {th }}$ principle of Green Chemistry: Design chemicals and products to degrade after use: design chemical products to break down to innocuous substances after use so that they do not accumulate in the environment. [9]. Both the biotic and the abiotic degradabilities of organic chemicals are largely influenced by the potential exposure of substances to organisms and, hence, are key parameters in risk assessment for predicting spatio-temporal environmental concentrations and long-term adverse effects on biota (potentially resulting in disorders, effects on reproduction, genetic mutation, cancer, mortality and adverse effects on the immune and nervous systems).

Degradability in particular could be a bottleneck in designing inherently safer and sustainable ILs, because the tendency of certain ILs to be thermally and chemically very stable is often reflected by their great vis-à-vis biological degradation processes [18]. In parallel with rapidly expanding (eco)toxicological knowledge, more and more data on biodegradability is becoming available. The following sections will provide an introduction to biodegradation test procedures and will present an overview of existing aerobic and anaerobic IL biodegradation data. Besides pure biodegradation kinetics, data on biological degradation products (metabolites) and abiotic degradation processes are discussed. Throughout this review special emphasis will be on structure-biodegradability relationships and on whether the $10^{\text {th }}$ principle of Green Chemistry is fulfilled for IL structures. The discussion of this data should help to improve the future design of inherently safer ILs and thereby to reduce the risks they may pose to humans and the environment.

\section{BIODEGRADABILITY TEST METHODOLOGIES: PRINCIPLES AND GLOSSARY}

In its simplest definition biodegradation can be described as the breakdown of an organic substance by enzymes produced by living organisms. Several laboratory test methodologies have been developed and standardized, for instance, by the Organization for Economic Co-operation and Development (OECD), to simulate environmental biodegradation processes and to estimate the probable concentration of organic compounds in the environment [19]. For every type of biodegradation experiment a test substance is brought into contact with a mixed population of microorganisms (the inoculum) - from surface waters, aquatic sediments, soils or waste water treatment plants - in a solution of inorganic nutrients under standardized conditions (e.g., concentration of inoculum, $\mathrm{pH}$, temperature, test duration, substance concentration). In general, biodegradation in these tests is caused predominantly by bacteria, but other microorganisms like protozoa, rotifers, and higher forms of invertebrates may also be involved.

The OECD proposes a tiered test strategy to evaluate the aerobic biodegradability of chemicals [19], using concepts and terms like "ready biodegradability", "ultimate biodegradation", and "inherently biodegradable". These terms, the strategy behind different test procedures and their relevance within the assessment of biodegradability of chemicals are summarized in the following passages:

\section{Ready Biodegradability (for example, according to OECD test protocols $301 \mathrm{~A}-\mathrm{F}$ [20])}

"Readily biodegradable" is an arbitrary classification of chemicals which have passed a screening test for ultimate biodegradation (complete mineralization of the test chemicals to inter alia $\mathrm{CO}_{2}$, $\mathrm{H}_{2} \mathrm{O}, \mathrm{NO}_{3}{ }^{-}$). A ready biodegradation test is based on stringent conditions (high ratio between test chemical concentration and cell density of inoculum, not pre-exposed to the test chemical, only inorganics in the medium). With respect to typical environmental conditions this test is not realistic, but it is of significance especially in the context of environmental legislation. When a chemical passes this test procedure it can be assumed that it is very likely to be readily biodegradable in the environment. These chemicals come with just a low risk of persistency, or even none at all. But even if a chemical fails this test, it does not necessarily follow that it will not degrade in the environment, and further testing will be necessary to clear this initial suspicion of persistency.

Inherent Biodegradability (for example, according to OECD test protocols $302 \mathrm{~A}-\mathrm{C}$ )

For chemicals that do not fulfill the criteria of the stringent ready biodegradation test conditions, the OECD proposes to investigate the inherent biodegradability of compounds [19]. "Inherently biodegradable" is a classification for which there is unequivocal evidence of (partial) biodegradation. An inherent biodegradation test is based on more unconstrained and environmentally more realistic test conditions (lower ratio of test chemical concentration to cell density of inoculum, use of an inoculum pre-exposed to the test chemical, addition of organic co-substrates to the medium). Thus, if a chemical fails the inherent test, there is a high probability that it is non-readily biodegradable in the environment [19] and consequently poses an elevated risk of persistency. However, even if the chemical passes the inherent test, it does not necessarily follow that it will degrade in the environment. Only some inherently biodegradable chemicals will degrade in the (following) simulation test.

\section{Simulation Test (for example, according to OECD test protocol} 303)

Simulation tests are designed to determine the elimination and the primary degradation (i.e., the biological production of organic derivatives which exhibit their own properties and fates) and/or the ultimate biodegradation of organic compounds by aerobic microorganisms in a continuously operated test system simulating, for example, the activated sludge process. Some systems closely mimic 


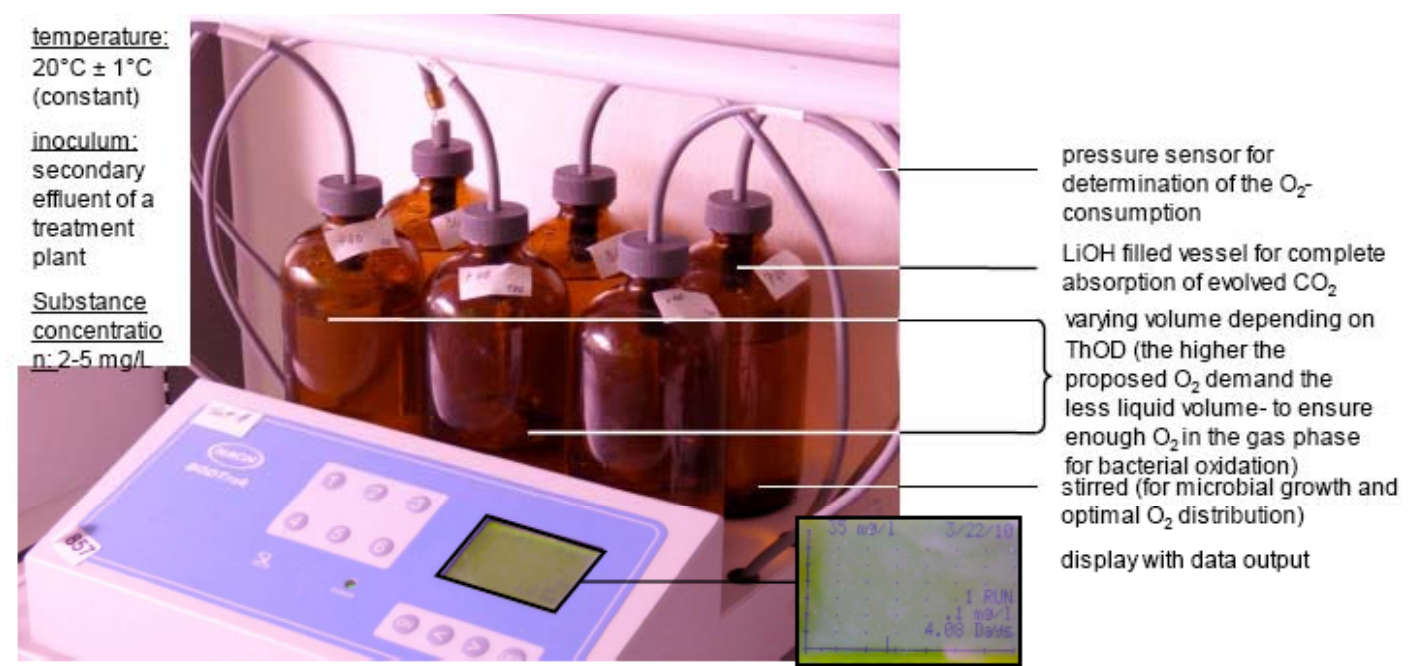

Fig. (1). Device for measuring the biochemical oxygen demand to follow the ultimate biodegradability of chemicals.

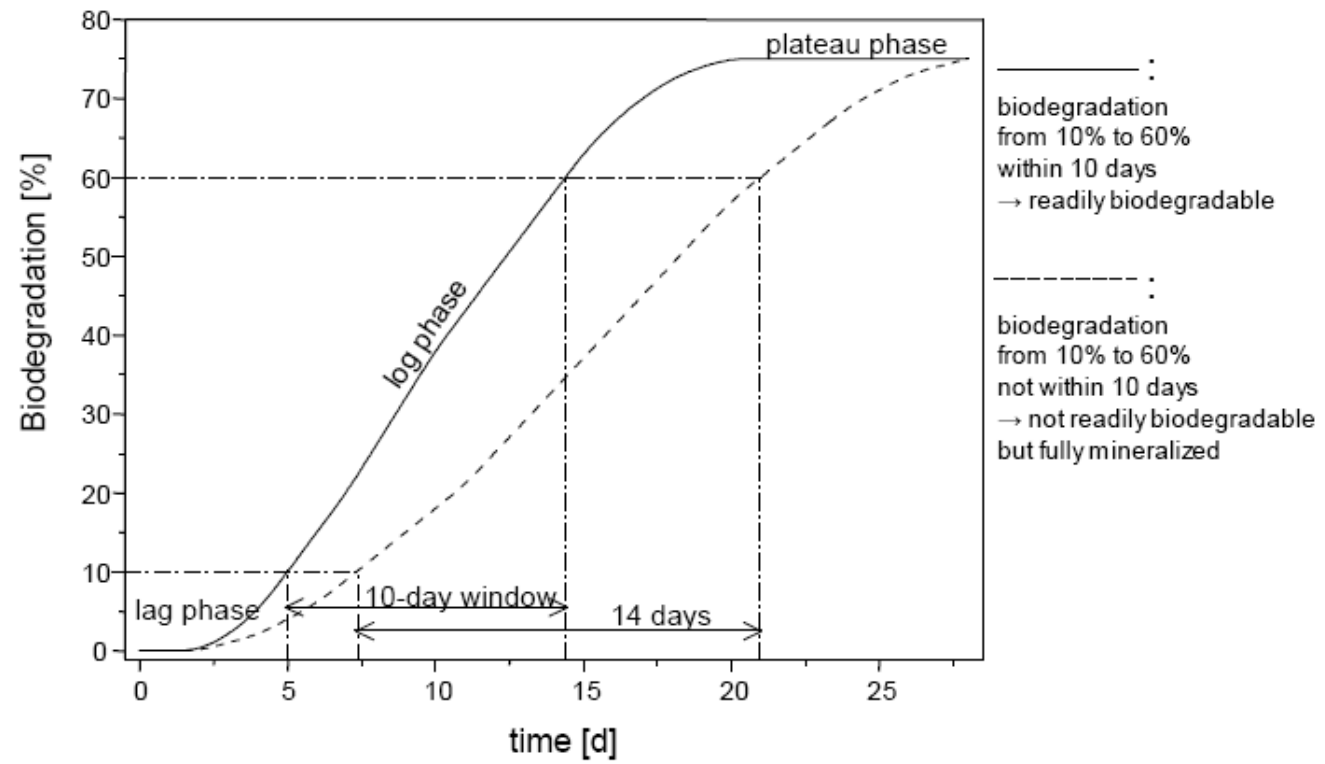

Fig. (2). Typical biodegradation curve: Period of acclimatization/adaptation of a microorganism with less than 10\% biodegradation of the test compound (lag phase), degradation phase (log phase) and reaching a maximum level of degradation (plateau phase).

full-scale plants, having sludge settlement tanks with settled sludge being pumped. Within this test very low and realistic environmental concentrations of chemicals in the $\mu \mathrm{g} / \mathrm{L}$ range are commonly used, which often goes hand in hand with the need to use ${ }^{14} \mathrm{C}$ labeled compounds. In general, a simulation test is associated with relatively high cost and effort, but it allows for a more precise and more realistic assessment of biodegradability compared to the abovementioned screening tests.

\section{Monitoring the Course of Biodegradation}

For ready, inherent and simulation tests different methods can be used to follow the course of degradation. Inherent and simulation tests are (mainly) based on specific analytical techniques like high performance liquid chromatography (HPLC) or gas chromatography (GC). Here, the degradation of the parent compound is measured, but not its complete mineralization to, say, $\mathrm{CO}_{2}, \mathrm{H}_{2} \mathrm{O}, \mathrm{NO}_{3}{ }^{-}$. The complete mineralization of chemicals (used for ready biodegradation tests) can be followed by applying non-specific composite parameters like dissolved organic carbon $(\mathrm{DOC}), \mathrm{CO}_{2}$ production or biochemical oxygen demand (BOD). These integral parameters have the advantage of being applicable to a wide variety of organic substances and of responding to any biodegradation residues or transformation products. For example, BOD is measured by using an oxygen electrode or via manometric respirometry and represents the amount of oxygen consumed by microorganisms when metabolizing the organic test chemical (Fig. 1).

The biodegradation rate is calculated from the ratio between the oxygen consumption caused by the degradation of the test item corrected by the blank values (composed just of inoculum and media, but without the test chemical), and the theoretical oxygen demand (ThOD). ThOD can be calculated from the molecular formula and represents the total amount of oxygen required to completely oxidize a chemical. A degradation extent of at least $60 \%$ ThOD is defined as the criterion for classifying a particular test substance as "readily biodegradable". These $60 \%$ pass levels have to be reached within a 10-day window (which begins when the degree of biodegradation has reached $10 \%$ ) during the 28-day test (Fig. 2). This additional hurdle was introduced to take into account adaptation 
processes of microorganisms toward the chemicals that could occur during the 28-day test period.

Additionally, experiments with a sterilized inoculum have to be carried out to check for possible non-biological degradation and for adsorption processes of the test chemical to the organic matter of the inoculum. Furthermore, to determine whether the test chemical inhibits the inoculum, tests with a mixture of a readily biodegradable reference compound and the test chemical are necessary.

\subsection{Variability of Biodegradation Tests}

In general, the assessment of biodegradability is a very complex field. The results are strongly dependent on the kind of degradation test performed and on the composite parameters used. Each test procedure has its own intrinsic advantages and drawbacks, which can result in very different degradation rates for one chemical when different methods are applied. Furthermore, the intrinsic variability of biodegradation test methods can lead to different results for one compound using the same test system. This might lead to the conclusion that results from biodegradability studies have no validity, but these measurements are not comparable with the determinations of simple properties like melting points or viscosities - for which there is only one correct value [21]. Especially the nature of the inoculum (subject to spatial and temporal variations) is a very variable factor within the assessment of biodegradability. For every experiment a unique microorganism community is used, which comes with a restricted reproducibility based on biological variability.

To handle this cascade of complexity - based on different available testing methodologies and on biological variability - the interpretation of results should be guided by the following question [21]:

"Which test was performed under what conditions and with which microorganisms?"

If biodegradation was observable two questions arise, namely, "at what rate?" and "breakdown to what?". Without careful consideration of these questions, the results of biodegradability studies can lead to false or contradictory conclusions. In particular, the unwary interpretation of empirically pre-assigned pass levels $(>60 \%$ biodegradation $=$ readily biodegradable $)$ can be misleading in the development of completely biodegradable chemicals, as will become apparent in the following sections.

\subsection{General Factors Affecting the Biodegradability of Com- pounds}

So far, biodegradability test procedures, their variability and interpretation have been presented and discussed, but no answers have yet been given regarding the real causes of biodegradability or persistency. The main factor affecting the biodegradability of a compound is its molecular structure, although exposure and environmental conditions can also have an influence. Fewson summarized possible reasons for the recalcitrance of molecules in general [22], stating that probably nothing distinguishes the biodegradability of xenobiotic chemicals from that of naturally occurring materials. For both groups the following generalizations for the recalcitrance of chemicals can be made (adapted from [22,23]):

1) reasons based on environmental conditions

appropriate microorganisms do not exist, or are not present

in the environment or in the relevant environmental compartment;

the nutrient level is inadequate to sustain the microbial population; the temperature, salinity, $\mathrm{pH}$ or $\mathrm{pO}_{2}$ is too low or too high; the concentration of the substrate is too high or too low; the substrate is adsorbed or covalently attached to clays, humus etc., or is physically inaccessible;

the substrate is not accessible to attack because it is too large and/or insoluble.

2) reasons based on properties of the chemical's molecular structure:

- it is not transported into the cell;

- it is not a substrate for available enzymes;

- it is not an inducer of appropriate enzymes or transport systems;

- it does not give rise to products that can integrate into normal metabolism;

- it is converted into products that are toxic or interfere with normal metabolism.

This issue will be taken up for IL structures in the concluding remarks, but the following sections are intended to give the reader a comprehensive overview of IL structure-biodegradability relationships.

\section{BIODEGRADATION STUDIES OF IONIC LIQUIDS}

Over the past eight years some 25 papers and a few reviews [13,23-25] have reported on the biodegradability of different ionic liquid structures, mainly according to "ready biodegradability" test procedures under aerobic conditions. Fundamental studies in the field were performed by the groups of Scammels [26-32] and Gathergood [26-29,33]. Guided by their knowledge of the development of biodegradable surfactants, they investigated different imidazolium, pyridinium or phosphonium compounds substituted with side chains containing e.g. ester, ether, polyether and amide functional groups combined with several anions in different tests for ready biodegradability. Wells and Coombe [17] investigated the biodegradability of ammonium, imidazolium, phosphonium and pyridinium compounds by measuring the biochemical oxygen demand (BOD). N-methyl-imidazolium and 3-methylpyridinium compounds substituted with butyl, hexyl and octyl side chains and bromide as the anion were examined by Docherty et al. [34,35], who applied a dissolved organic carbon (DOC) die-away test. Stolte et al. [18] investigated different imidazoles, imidazolium, pyridinium and 4-(dimethylamino)-pyridinium compounds substituted with various alkyl side chains and their analogs containing functional groups in a primary biodegradation test and were able to identify different biodegradation products from the 1-methyl-3octyl-imidazolium cation (IM18). Recently, several biological degradation products have also been identified for alkyl-pyridinium compounds by the teams associated with Pham [36], Docherty [35] and Zhang [37]. Stepnowski et al. [38] used the closed bottle test to examine the biodegradability of 1-alkoxymethyl-3-hydroxypyridinium cations combined with acesulfamate, saccharinate and chloride anions. A set of oxygenated and non-oxygenated imidazoliumbased ILs was investigated by Modelli et al. [39] in experiments with microorganisms from soil.

Markiewicz et al. [40] explored the primary biodegradation and sorption on sewage sludge flocs of IM18 with respect to its concentration. The first results obtained from inherent biodegradability test procedures using an inoculum from an industrial wastewater treatment plant were presented at the BATIL 2 (Biodegradability and Toxicity of Ionic Liquids) Conference [41]. Lately, the anaerobic 
Inorganic anions:

$$
\underbrace{\mathrm{Cl}^{-} \mathrm{Br}^{-} \mathrm{I}^{-} \mathrm{BF}_{4}^{-} \mathrm{PF}^{-}}_{\text {cannot serve as }}
$$

\section{sulfates:}

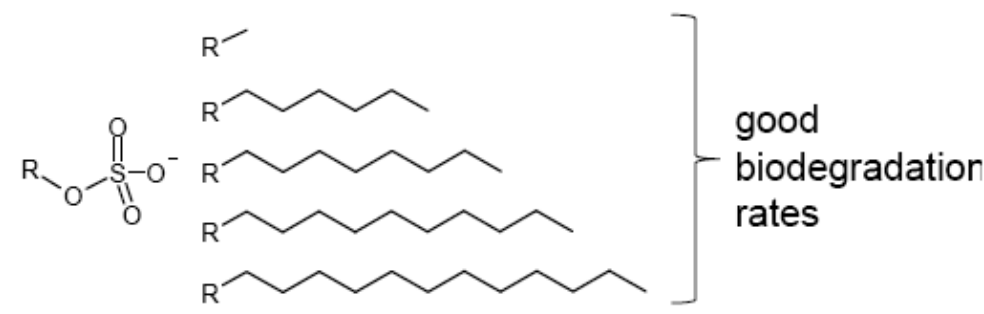

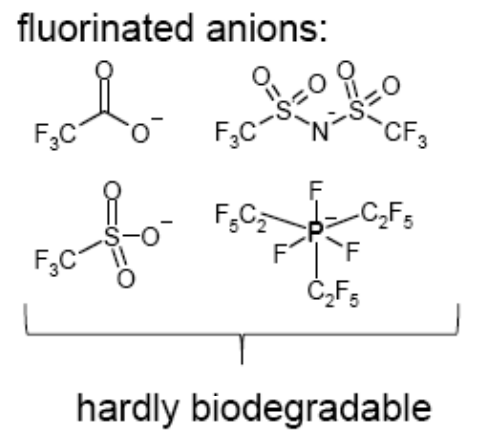

anions from biomaterial:<smiles>CCC(=O)[O-]</smiles><smiles>O=C([O-])C=CC(=O)CCC(=O)[O-]</smiles>

Fig. (3). Anion structures and their biodegradability.

biodegradability and metabolization of nine different imidazolium, pyridinium and dimethylaminopyridinium-based cations were examined over a period of 11 months.

Based on the publications referred to above, an overview on available aerobic biodegradation data (including the test procedures and conditions) for IL structures is given in Appendices A-C. In the following, the biodegradabilities of anions and cations are discussed separately.

\subsection{Biodegradability of Ionic Liquid Anions}

Most IL anions investigated so far (Fig. 3; Appendix A-C) are inorganic moieties (halides, $\left[\mathrm{BF}_{4}\right]^{-},\left[\mathrm{PF}_{6}\right]^{-}$), which are not relevant to biodegradation tests based on the measurement of oxidizable carbon in the molecule. Abiotic degradation processes are more important for inorganic anions (see the "abiotic degradation" section). Nonetheless, some IL anions are potentially amenable to microbial degradation, because they can serve as a carbon source. It is known from research on anionic surfactants [42] that linear alkylsulfates (like methylsulfate or octylsulfate) exhibit excellent biodegradability, and linear alkylsulfonates (like methyl sulfonate) display good biodegradability, as do linear alkylbenzene sulfonates (like p-toluenesulfonate).

The good biodegradability of octylsulfate [28-31,33] and series of alkylsulfates (from methyl, hexyl to decyl and dodecyl) [31] is demonstrated even when they are combined with an IL cation. In BOD experiments the diethylphosphate anion was found to be readily biodegradable [17], whereas dibutylphosphate was not significantly degraded in a $\mathrm{CO}_{2}$ headspace test [31]; this is unusual, considering that both phosphates were tested with cations that did not inhibit the activity of the inoculum. The non-specific influence of the anion compared to the chloride compounds has been suggested for different 1-alkoxymethyl-3-hydroxypyridinium acesulfamates and saccharinates [38]. A lot of toxicological data are available for the food additives potassium acesulfamate and saccharin, but there are little or none regarding their biodegradation in the environment. For instance, the ready utilization of saccharin by the bacterium Sphingomonas xenophaga, enriched and isolated from a communal wastewater treatment plant, is described [43]. Harjani et al. also reported increased $\mathrm{CO}_{2}$ evolution when IM14 (non-biodegradable under the chosen conditions) was combined with saccharin [31]. Several ILs based on biomaterials have been developed using biodegradable anions like lactate [44], tartrate [44,45], acetate, propionate, benzoate, fumarate or succinate [45] (Fig. 3).

Likewise, little information was found on the biodegradation behavior of typical fluorine-containing ionic liquid anions (e.g., $\left.\left[\left(\mathrm{CF}_{3} \mathrm{SO}_{2}\right)_{2} \mathrm{~N}\right]^{-}, \quad\left[\left(\mathrm{C}_{2} \mathrm{~F}_{5}\right)_{2} \mathrm{PO}_{2}\right]^{-}, \quad\left[\left(\mathrm{C}_{2} \mathrm{~F}_{5}\right)_{3} \mathrm{PF}_{3}\right]^{-}, \quad\left[\left(\mathrm{C}_{3} \mathrm{~F}_{7}\right)_{3} \mathrm{PF}_{3}\right]^{-}\right)$. The tendency of these anions to be thermally and chemically stable is presumably mirrored by their resistance to biological degradation [13]; indeed, many synthetic halo-organics have been found resistant to aerobic biodegradation [46]. In line with this statement, $\left(\mathrm{CF}_{3} \mathrm{SO}_{2}\right)_{2} \mathrm{NH}$ was found to be non-biodegradable in ready biodegradability tests [17]. These fluorinated anions in particular have the potential to persist in the environment and, because of their high lipophilicity, to accumulate in the tissues of living organisms. The ionic liquid anion trifluoroacetate is known to be recalcitrant to biodegradation [47], and a similar behavior can be postulated for the salts of trifluoromethanesulfonic acid (triflates). Nevertheless, the bioaccumulation of both compounds is thought to be unlikely owing to their low octanol/water coefficients.

Cyano-complexes like $\mathrm{B}(\mathrm{CN})_{4}{ }^{-}$and $\mathrm{C}(\mathrm{CN})_{3}{ }^{-}$, which are known to form hydrophobic ILs (comparable to the $\left(\mathrm{CF}_{3} \mathrm{SO}_{2}\right)_{2} \mathrm{~N}^{-}$anion), are of great relevance to technical applications. However, no degradation data for ILs containing these anions are yet available. In the study of Garcia et al. the slightly biodegradable 3-methyl-1(propoxycarbonyl)-imidazolium cation was combined with $\mathrm{N}(\mathrm{CN})_{2}$ and increased oxygen consumption was found, which is indicative of the microbial degradation of this anion [28]. Generally, K, CN 


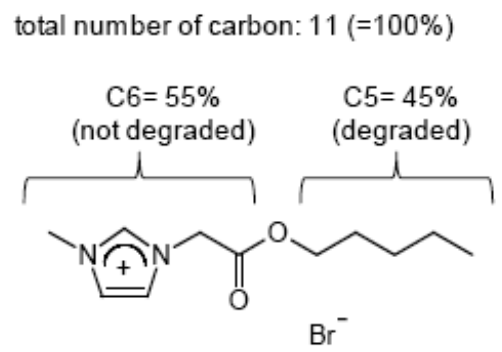

found biodegradation rate $\left(\mathrm{CO}_{2}\right.$ test $)=41 \%$ (appendix 1, No. 62c) total number of carbon: $19(=100 \%)$

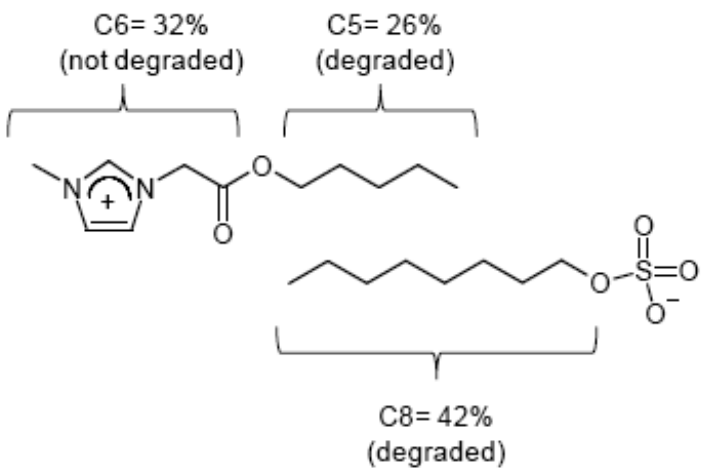

found biodegradation rate $\left(\mathrm{CO}_{2}\right.$ test $)=67 \%$

(appendix 1, No.63b)

Fig. (4). Misleading interpretation of biodegradation data. The $60 \%$ degradation threshold is exceeded by using a very readily biodegradable anion. However, the cation core remains recalcitrant to biodegradation.

total number of carbon:11 (=100\%)

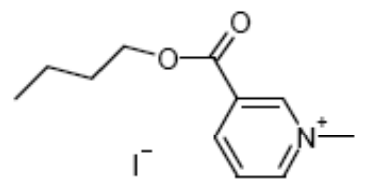

found biodegradation rate $\left(\mathrm{CO}_{2}\right.$ test $)=74 \%$

(appendix 2, No.97) total number of carbon:13 (=100\%)

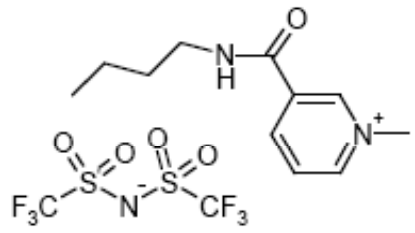

found biodegradation rate $\left(\mathrm{CO}_{2}\right.$ test $) \sim 65$

(appendix 2, No. 99)

Fig. (5). Misleading interpretation of biodegradation data. The $60 \%$ degradation threshold is exceeded by using a very readily biodegradable cation. However, the anion remains recalcitrant to biodegradation.

and complex bonded cyano-ligands in $\mathrm{K}_{2}\left[\mathrm{Ni}(\mathrm{CN})_{4}\right]$ are known to be biodegradable [48].

In general, when assessing the biodegradability of ILs one has to bear in mind that anions (whether biodegradable or not) may influence the biodegradability of a cation. For instance, the combination of a readily biodegradable cation (measured as halide) with a toxic anion may reduce cation biodegradability as a result of the different toxicity of the new cation-anion combination $[12,15,49]$. Moreover, if the anion reduces the water solubility of the cation, the biodegradation rate may likewise be reduced, because of the diminished availability of the cation to the microorganisms in the surrounding medium.

\subsection{Misleading Interpretation of Biodegradation Data}

Before the structure-biodegradability-relationships of ionic liquid cations can be discussed the interpretation of biodegradation data has to be clarified, especially when composite parameters like $\mathrm{CO}_{2}$ evolution or BOD are used. In general, the final result of such a test is expressed as "\% degradation" based on the total carbon content of the whole molecule (as explained in the section "Monitoring the course of Biodegradation"), which for ILs means the carbon content of both cation and anion. The fact that ILs are formed by two separate ionic species can lead to a misinterpretation of biodegradation results and to misleading or even false conclusions - as has already occurred in the case of some ILs (Appendix A, e.g., No. 59c, 63b, 71a or 81). These compounds have been classified as "readily biodegradable" according to, e.g., the $\mathrm{CO}_{2} \mathrm{Head}-$ space ISO test procedure, but this categorization is based on a misleading molecular design and the wrong declaration of chemicals. To give an example (Fig. 4), a biodegradation rate of $41 \%\left(" \mathrm{CO}_{2}\right.$ Headspace" test) was found for the 1-(pentoxycarbonyl)-3methylimidazolium cation (tested as bromide). This percentage corresponds quite well to the oxidizable C-content of the ester side chain (Fig. 4) or rather to the pentanol formed after the suggested enzymatic hydrolysis. This means that the core structure is neither touched nor degraded by the microorganisms and may well be resistant to further biodegradation. The authors of this study recommended the combination of this cation with the excellently biodegradable octylsulfate anion. Of course, this is accompanied by an increase in biodegradability (now the $\mathrm{C}$-content of the biodegradable parts of the side chain and of the anion exceeds the OECD level of $60 \%$; see Fig. 4). However, this putative "readily biodegradable" compound still contains a non-biodegradable core structure. Even more misleading is the "ready" classification of substance No. 99 (Appendix B). This ionic liquid is formed by a readily biodegradable cation and the non-biodegradable $\left(\mathrm{CF}_{3} \mathrm{SO}_{2}\right)_{2} \mathrm{~N}^{-}$ anion. In this case, the $\mathrm{C}$-content of the cation is overbalanced and the $\mathrm{C}$-content of the anion does not contribute significantly to the overall C-content of the ionic liquid's structural formula (Fig. 5) Thus, the measured $\mathrm{CO}_{2}$ evolution is more or less exclusively related to the cation. IL No. 99 , containing the $\left(\mathrm{CF}_{3} \mathrm{SO}_{2}\right)_{2} \mathrm{~N}^{-}$anion, is thus classified as readily biodegradable, which is a fundamental mistake, because this anion is non-biodegradable and potentially persistent. 


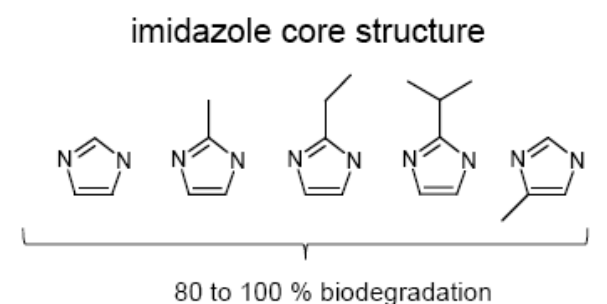

80 to $100 \%$ biodegradation
$\mathrm{N}$-substituted imidazole core structure

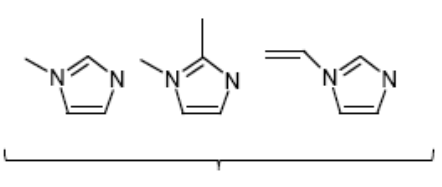

less than $10 \%$ biodegradation

Fig. (6). Biodegradability of imidazole structures.

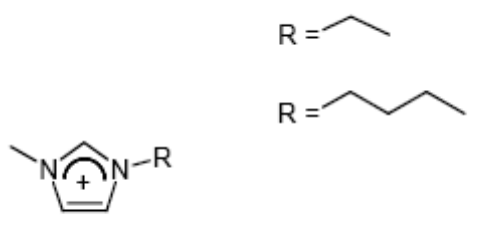

Fig. (7). Biodegradability of N-alkylated imidazolium structures.

In consequence, in the structural design of a biodegradable IL, a metabolizable cation has to be combined with a biotically or abiotically degradable anion.

The interpretation of "pure" biodegradation rates and the misconstruction of pass levels can result in erroneous conclusions with respect to the design of non-persistent ILs. Ideally, ILs (and chemicals in general) should not be classified in this arbitrary manner. The aim of biodegradation experiments should not be to exceed certain threshold values, but to find out whether or not a chemical or a combination of chemicals (like ILs) and their initial conversion products undergo further and rapid metabolization, ending in complete biodegradation.

\subsection{Aerobic Biodegradability of Ionic Liquid Cations}

This section will discuss the structure-biodegradability relationships of ionic liquid cations. To avoid "anion-fudged" degradation values for the cations, just the data will be considered when the cation is combined with an inorganic anion - ideally a halide to exclude toxic effects of the anion on the inocula - or the degradation data will be corrected for the C-content of the biodegradable anion.

\subsubsection{Biodegradability of Imidazolium Compounds}

Most IL biodegradation studies have been carried out on compounds with an imidazolium core structure substituted with different side chains and combined with several anions (Appendix A gives a comprehensive overview of test chemicals, test procedures and results). To identify structure-biodegradability relationships the core structure and its substituents are discussed exclusively without considering the anion. This is possible when an inorganic anion was tested or the \% degradation of the ionic liquid is corrected for the degradability of the organic anion portion according to Figure 4.

The imidazole ring itself and its ring $\mathrm{C}$-substituted derivatives (methyl, ethyl) are known to be ultimately biodegradable, whereas all $\mathrm{N}$-substituted imidazole compounds, like N-methylimidazole, are poorly biodegradable (Fig. 6) [50]. A possible explanation for the poor biodegradability of $\mathrm{N}$-alkylated imidazoles is that $\mathrm{N}$ - substitution apparently blocks attack by enzymes on the urocanase pathway, which are responsible for the enzymatic degradation of the imidazole containing the amino acid histidine [50,51].

Enhanced biodegradability for compounds with elongated alkyl side chains (C6 and C8) was found in twice N-alkyl-substituted imidazolium ILs (Fig. 7). These compounds can be described as "inherently biodegradable" and "partially mineralizable". However, results from HPLC [18] as well as from NMR [34] analysis indicate that the side chain is degraded but that the core structure remains resistant to biodegradation under the conditions of ready biodegradability test procedures. The increased biodegradability of compounds with long side chains can be explained in at least two ways $[18,34]$. Firstly, it has been demonstrated that ILs with elongated side chains are more toxic [52,53], therefore inducing a selective pressure on the microbial community. Microorganisms capable of degrading ILs with longer alkyl chains are privileged, whereas others that are unable to metabolize these ILs are eliminated. This assumption was proven by Docherty et al. [34], who analyzed the structure of the microbial community by DNA-PCR DGGE (denaturing gradient gel electrophoresis) and found that samples treated with $[\mathrm{IM} 18]^{+}$were richer in certain bacteria species. A second explanation is based on increased uptake into the organisms, which is also related to the hydrophobicity of the compounds. Owing to this (higher) uptake the substances can be metabolized by appropriate enzyme systems, for instance, by the cytochrome P450 system located in the endoplasmic reticulum of cells.

However, the successive elongation of the side chain does not represent an opportunity to design biodegradable ionic liquid cations, because lengthening the alkyl side chain is associated with enhancing inhibitory effects on the microorganisms induced by the rising bacterial toxicity of these cations (Fig. 7). This was demonstrated by Wells and Coombe [17] for N-methyl-imidazolium compounds with C12, C16 and C18 alkyl side chains. Markiewicz et al. [40] also found a concentration-dependent inhibition of the inoculum for IM1 $8 \mathrm{Cl}$ at concentrations $>0.2 \mathrm{mM}$.

"Task-specific" [54] or functionalized [55] ILs with fine-tuned physicochemical properties have been designed through the incor- 


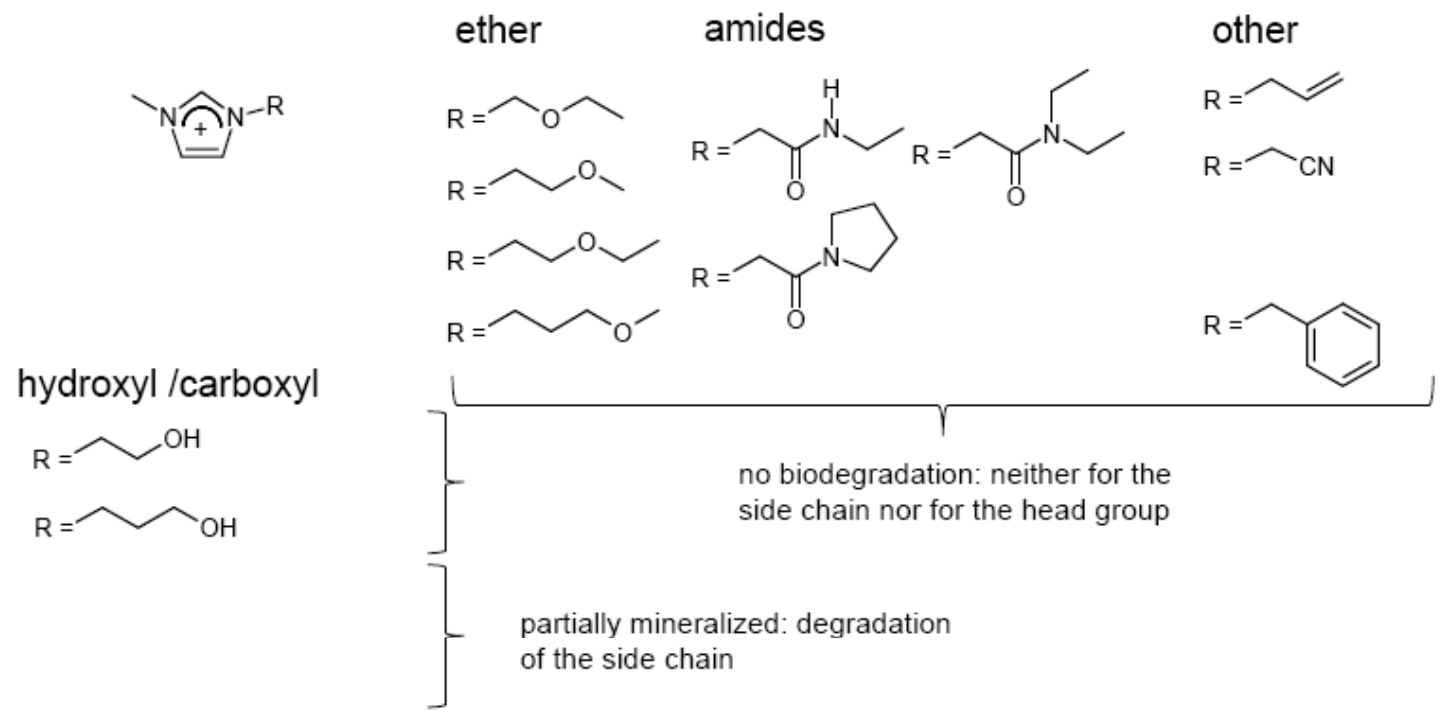

Fig. (8). Biodegradability of functionalized imidazolium structures.

ester

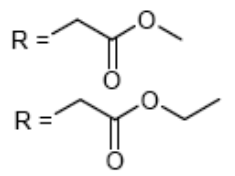

ester / alkoxy / polyether
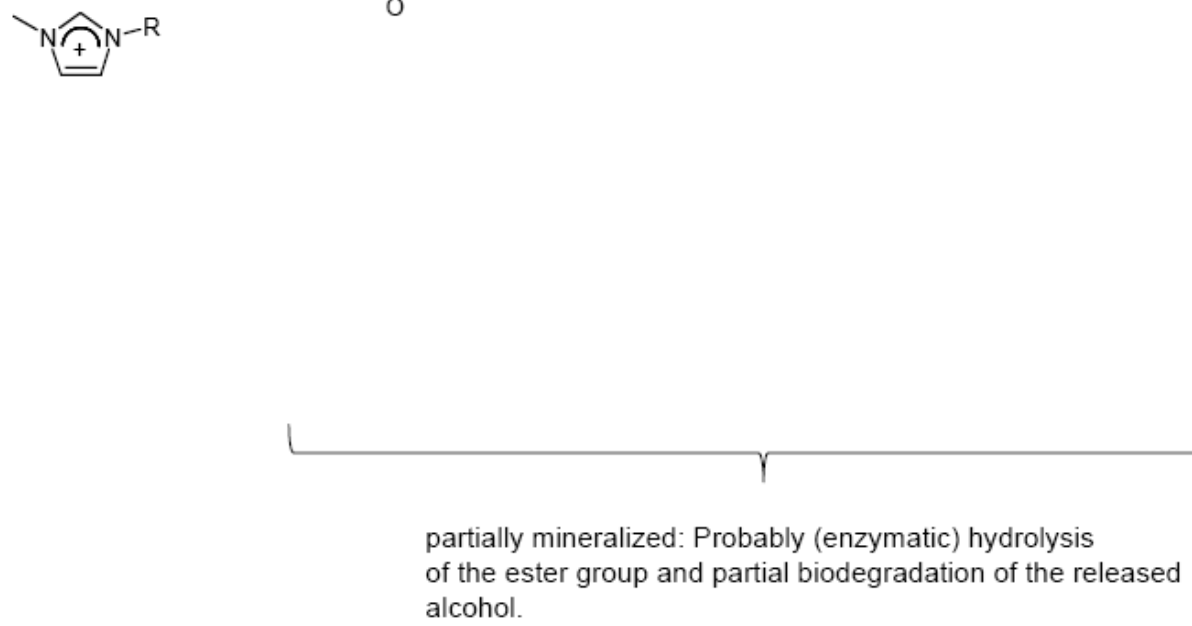

Fig. (9). Biodegradability of imidazolium-based ILs containing ester side chains.

poration of functional groups into the alkyl chains. The incorporation of functional groups increases the chemical reactivity of these compounds and, at the same time, the probability of biological (enzymatic) conversion. A series of imidazolium compounds substituted with functionalized side chains containing, for instance, ether, amide, nitrile, terminal hydroxyl and carboxyl groups, have been investigated according to the ready biodegradability test procedure (Fig. 8). Especially in the case of compounds substituted with short alkyl side chains $(<\mathrm{C} 4)$, even if functional groups are introduced, no significant biodegradation was observable in different biodegradation tests [18;31]. Whereas partial degradation of the side chain did take place in long-chain compounds (C8) containing hydroxyl and carboxyl groups, the results of HPLC analysis suggest that the imidazolium core structure was recalcitrant to biodegradation [18]. Here again, it can be concluded that a cation has to be distinctly hydrophobic if it is to be biodegradable, as discussed previously for alkyl substituted compounds.
Other attempts to improve biodegradation were made by Harjani et al., who substituted phenyl and allyl groups in the imidazolium core (Fig. 8). These groups might increase the chances of metabolism of the cation by redox enzymes [23], but this could not be proven for ILs.

A long list of imidazolium based ILs containing ester side chains (Fig. 9) were investigated in different biodegradation tests [26-29,31,33]. In general, the introduction of ester groups into the side chain resulted in a significant increase in biodegradation, especially of esters with an alkyl side chain length of $\geq$ C4 [29]. These ester groups represent a site of enzymatic hydrolysis (by esterases), which can explain the increased biodegradability of these compounds. The saponification of the ester side chain is accompanied by the formation of well biodegradable alcohol moieties (the longer the ester alkyl side chain, the longer the resulting alcohol, while the imidazolium ring seems to stay intact under these conditions.). This also holds true for compounds with additionally introduced alkoxy 
A)

$$
\text { domestic sewage } \longrightarrow
$$
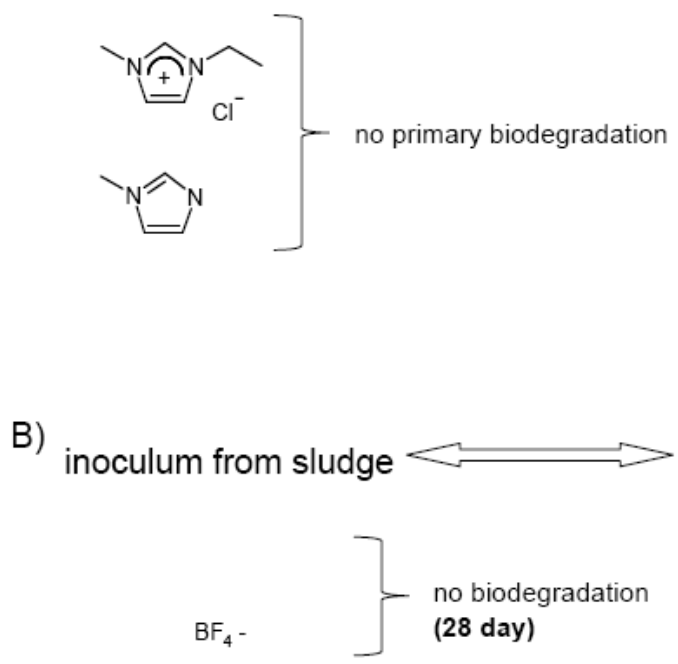

\section{industrial sewage}

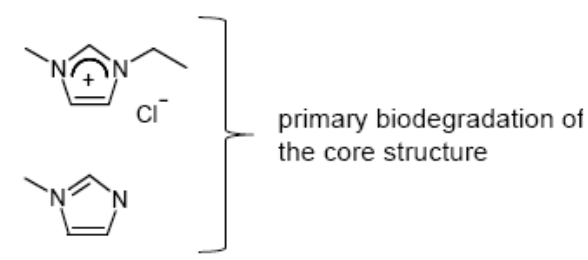

inoculum from soil

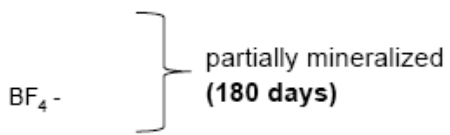

Fig. (10). Increased biodegradability of the imidazolium core structure under different test conditions.

or polyether chains. Higher levels of biodegradation were found for the ester ionic liquid cations combined with octylsulfate $[28,29,31,33]$. In some cases the benchmark of ready biodegradability was passed, but here the biodegradability found was driven mainly by the high biodegradability of the anion (as discussed in the section "misleading composite parameters").

All the results presented so far have been based on the stringent ready biodegradability test conditions, and within these tests the imidazolium core structures have been found recalcitrant toward microbial degradation even if the degradation rate can be increased by the choice of a degradable side chain. This leads to a first suspicion of persistency for IL cations based on the imidazolium core structure. However, according to the OECD, further testing is necessary (using inherent/simulation tests) to clear or verify this first suspicion of persistency, but to the best of our knowledge, very little information can be found for ILs to which these less stringent test procedures have been applied. At the BATIL 2 Conference it was stated that the imidazolium core structure itself could also be biodegraded over a test period of 28 days when an inoculum from an industrial waste water treatment plant was used instead of the OECD-recommended inoculum from domestic clarification plants [41]. Complete primary biodegradation of N-methylimidazole and 3-ethyl-1-methyl-imidazolium (IM12 Cl) was achieved (Fig. 10 part A), which can be explained by the microbial community of the inoculum used. Industrial sewage varies greatly in its microorganism composition and is composed of bacteria that are adapted to man-made chemicals, for instance, antibiotics, pesticides or heavy metals. This finding goes along with a reduced risk of persistency for compounds with the imidazolium core structure. However, because of the favorable conditions employed in these tests, the rapid biodegradation of these chemicals in the environment cannot generally be assumed [19].

When applying an ASTM D 5988 biodegradation test with soil as the source of microorganisms (Figs. 10 part B), Samori et al. [39] found an enhanced biodegradation rate for 1-butyl-3-methylimidazolium tetrafluoroborate (IM14 BF4). A possible explanation for this improved degradability could be that soil microorganisms are more capable of metabolizing the IM14 cation or that the test duration of 180 days allows for an adaptation of the microorganisms to the test chemical. But here this result reduces the risk of persistency and accumulation of imidazolium cations in the environment.

\subsubsection{Pyridinium and 4-(Dimethylamino)pyridinium Compounds}

Several biodegradation studies were carried out with ionic liquid cations based on $\mathrm{N}$-alkyl and $\mathrm{N}$-(ethoxycarbonyl) pyridinium, $\mathrm{N}$-alkylated nicotinic acid esters, N-butyl-nicotinamide, 1-alkoxymethyl-3-hydroxypyridinium and $\mathrm{N}$-alkyl-4-(dimethylamino)pyridinium (Appendix B).

The pyridine core structure itself and its derivatives are extensively used in industry as solvents and for the synthesis of a wide range of compounds (pharmaceuticals, paints, agricultural chemicals) and are discharged via waste waters by several industries or are often found at locations associated with coal processing [56,57]. Several aerobic microorganisms, capable of degrading pyridine and its derivatives, were isolated (Fig. 11) [51].

The primary biodegradation rate of $\mathrm{N}$-alkyl-pyridinium compounds (Fig. 12) increased with lengthening side chain; the results were similar to those found for the imidazolium head group, but the degree of degradation was generally higher for the pyridinium compounds. The test procedure does not state whether the N-octylpyridinium compound was fully mineralized.

For N-alkyl-3-methyl-pyridinium compounds (Fig. 12) there was a correlation between the length of the substituted alkyl chain and the mineralization including the pyridinium ring [34,35].

In two studies by the same group (applying the same test procedure) similar results were found for N-hexyl-3-methyl-pyridinium bromide (Py6-3Me $\mathrm{Br}$ ) and for N-octyl-3-methyl pyridinium bromide (Py8-3Me Br). The Py6-3Me cation was fully mineralized (95-97\%) after 41 or 49 days of incubation [34,35]; even if it cannot be classified as "readily biodegradable" it should not persist in the environment [34]. Nearly complete mineralization (92-96\%) of the Py8-3Me moiety was obtained within 25 [34] or 33 days [35], which meets the criterion for being classified as "readily biodegrad- 


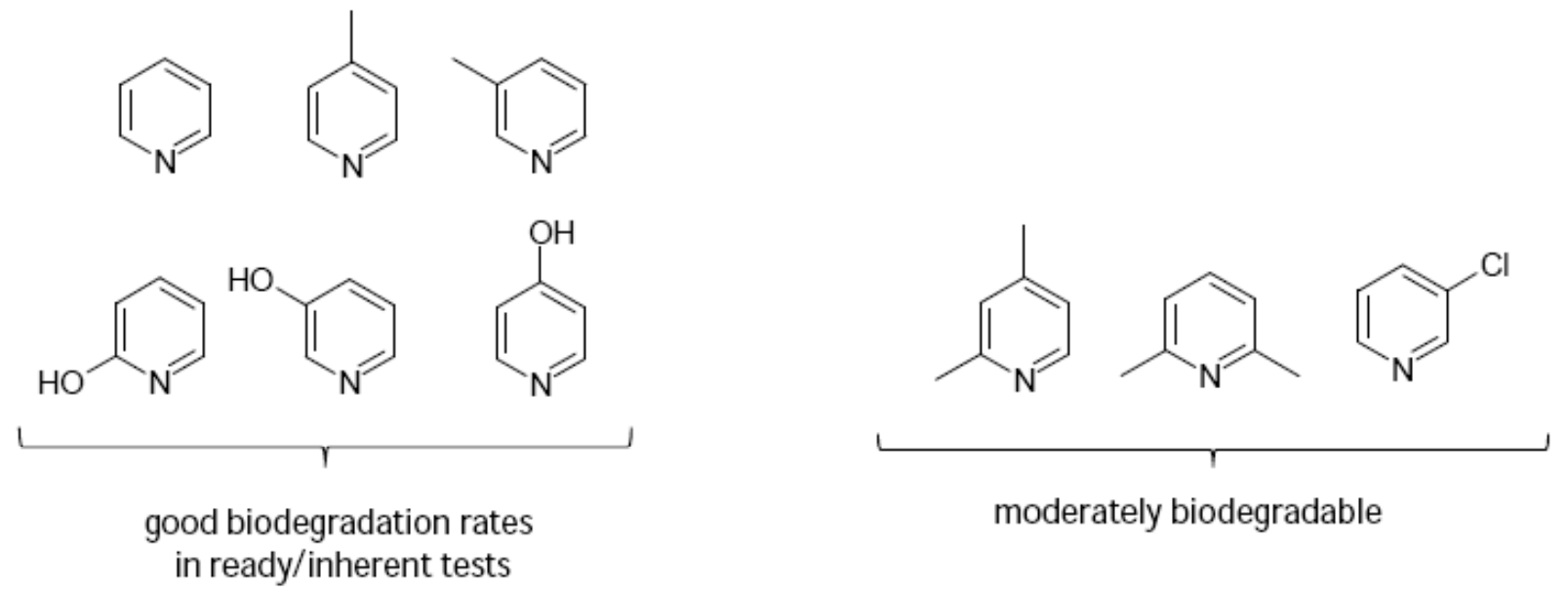

Fig. (11). Biodegradability of the pyridine core structure.
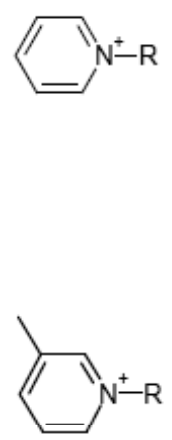

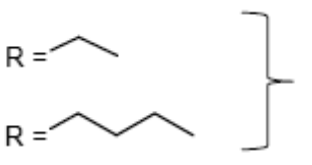

no biodegradation: neither for the side chain nor for the head group \} complete primary biodegradation

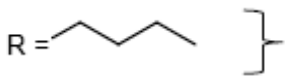

different degradation rates found in different studies - varying from non-degradable to completely mineralized

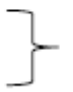

fully mineralized within 41 or 49 days respectively

fully mineralized within 25 or 33 days respectively / classified as readily biodegradable

Fig. (12). Biodegradability of N-substituted pyridinium compounds.

able". In contrast to the imidazolium core structure, the results from ${ }^{1} \mathrm{H}$ - and ${ }^{13} \mathrm{C}-\mathrm{NMR}$ measurements indicate that the pyridinium core structure was completely degraded during the biodegradation experiment [34]. Docherty et al. found clear differences in degradation rates when they re-examined the N-butyl-3-methyl-pyridinium compound (Py4-3Me). In a first study no biodegradation ( $0 \%$ degradation within 43 days) was observed [34], whereas in their second study, mineralization was nearly complete ( $88 \%$ within 41 days) [35]; these results were endorsed in primary biodegradation studies by Pham et al. [36].

According to Docherty et al., the different results were due to the microbial variation and composition of the activated sludge samples, which could have altered the degradation efficiency or even the ability to convert a chemical.

The biodegradability of the $\mathrm{N}$-(ethoxycarbonyl) pyridinium cation (Fig. 13) and the N-alkylated nicotinic acid esters (Fig. 13) is generally good (all are classified as readily biodegradable) [31]. The degradation rates of these cations as halides and as octylsulfate were similar (Appendix B, Nos. 97 and 98), which indicates that both organic ionic moieties have comparable percentages of biodegradability. In comparison to the N-butyl nicotinic acid ester, the structural homolog N-butyl-nicotinamide was significantly less biodegradable ( $81 \%$ versus $30 \%$ ) (Fig. 13) [31].
The biodegradability of 1-alkoxymethyl-3-hydroxypyridinium salts also improved slightly with increasing alkyl chain length, but only from $3(40 \%)$ to 11 carbon atoms (44\%) (Fig. 13), whereas the octadecyl compound exhibited a lower rate of biodegradability (25\%), probably due to its increased toxicity. However, for most of these ILs an intermediate rate of biodegradation was found [38].

Summing up, ionic liquid cations with a pyridinium core in general exhibit a higher degree of biodegradability than imidazolium derivatives, especially when an ester functional group is incorporated into the $\mathrm{N}$-side chain or if it is attached to the pyridinium skeleton. Thus, many pyridinium compounds can be classified as "readily biodegradable", and the core also appears to be accessible to aerobic biodegradation processes.

In primary biodegradation experiments with different N-alkyl4-(dimethylamino)pyridinium cations (Fig. 14 and Appendix B) no decomposition of ethyl and butyl substituted compounds was observed to take place, whereas complete primary degradation was detected for the hexyl derivative [18]. However, the ultimate biodegradability of this structure has yet to be investigated.

\subsubsection{Phosphonium Compounds}

There is little information in the literature regarding phosphonium-based ILs (Appendix C). Wells and Coombe investigated 


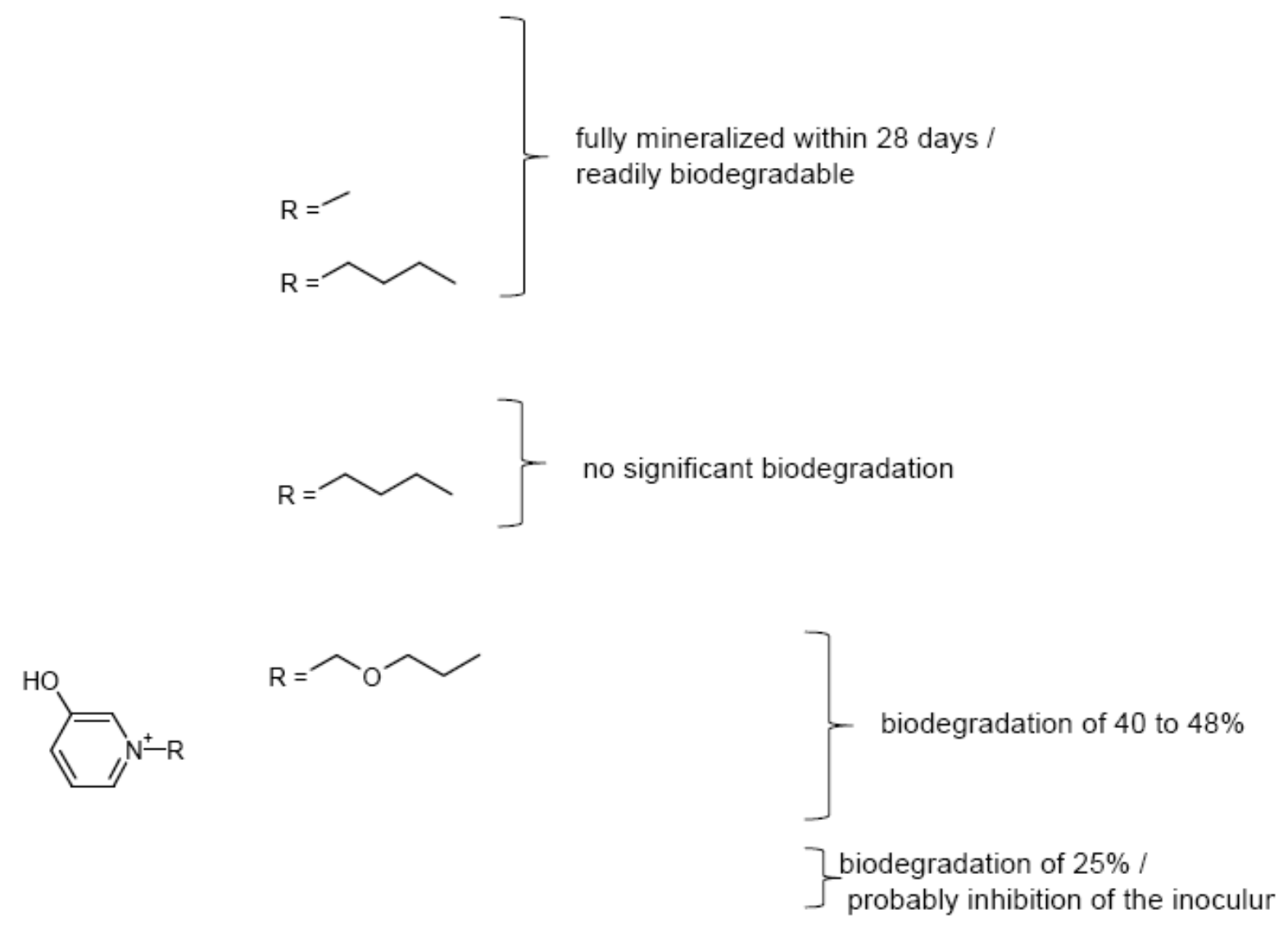

Fig. (13). Biodegradability of ester, amide and ether substituted pyridinium compounds.
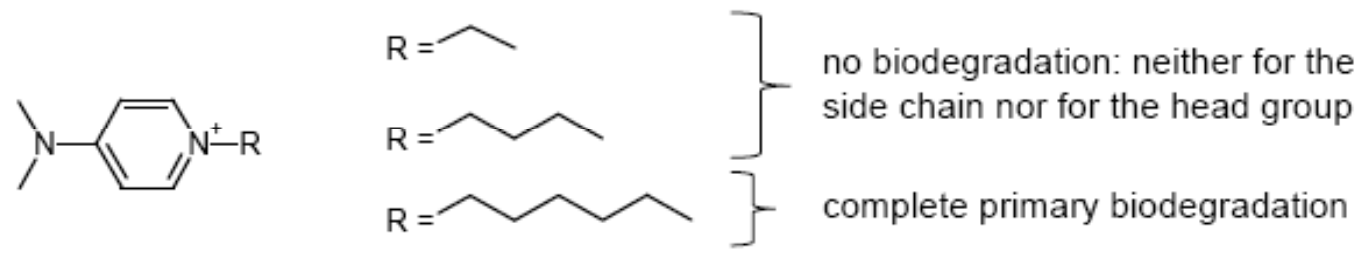

Fig. (14). Biodegradability of N-alkyl-4-(dimethylamino)pyridinium compounds.

alkyl substituted compounds like tributylethylphosphonium diethyl phosphate (P2444 (2O)2PO2) and trihexyltetradecylphosphonium chloride (P666-14 Cl) (Fig. 15). In P666-14 $\mathrm{Cl}$ the inoculum was strongly inhibited at concentrations of 1 to $100 \mathrm{mg} / \mathrm{L}$, which is in accordance with the high microbial toxicity of substituents with long alkyl chains. In contrast, the compound with the shorter side chains did not inhibit the inoculum strongly, so no significant biodegradation was observed.

Atefi et al. synthesized and assessed the biodegradability of a set of tri-n-hexyl and tricyclohexyl phosphonium ILs using a $\mathrm{CO}_{2}$ headspace test [32]. Tri-n-hexyl cations have been linked to several alkoxycarbonylmethyl residues (methoxy, propoxy, pentoxy) (Figs. 16 and 17).

The assumption of the authors, that the biodegradation of these molecules may be initiated by simple hydrolytic cleavage of the ester bond leading to a tri-n-hexyl / tricyclohexylphosphonium fragment and the corresponding primary alcohol and carboxylic acid that can be readily metabolized via the pathway of fatty acid Boxidation [32], could not be confirmed. Regardless of the length of the alkoxy residue, a low biodegradation rate of $<10 \%$ was deter- mined for all tricyclohexylphosphonium cations (Fig. 17). Likewise, no significantly higher biodegradability could be detected for tri-n-hexyl compounds with substituted ester or with ether, hydroxyl or allyl functionalized side chains (Fig. 16). Higher degradation rates have been found by combining phosphonium-based cations with octylsulfate as counter anion (Appendix C), but here again this observation is based on the good biodegradability of the anion moiety (as mentioned in previous sections). Tri-n-hexyl and tricyclohexyl phosphonium ILs showed some degree of inhibition (up to 28 for the allyl compound) of the inoculum activity when tested as halide [32]. These slightly toxic effects may decelerate but not prevent biodegradation.

\subsubsection{Other Head Groups}

Very little biodegradation information for ILs with ammonium head groups has been published (Appendix C). However, several studies were performed for quaternary ammonium compounds, which are used as cationic surfactants in a number of applications (softeners, emulsifiers, disinfectants and so on). The ammonium structures are often substituted with benzyl, 2-hydroxyethyl or un- 

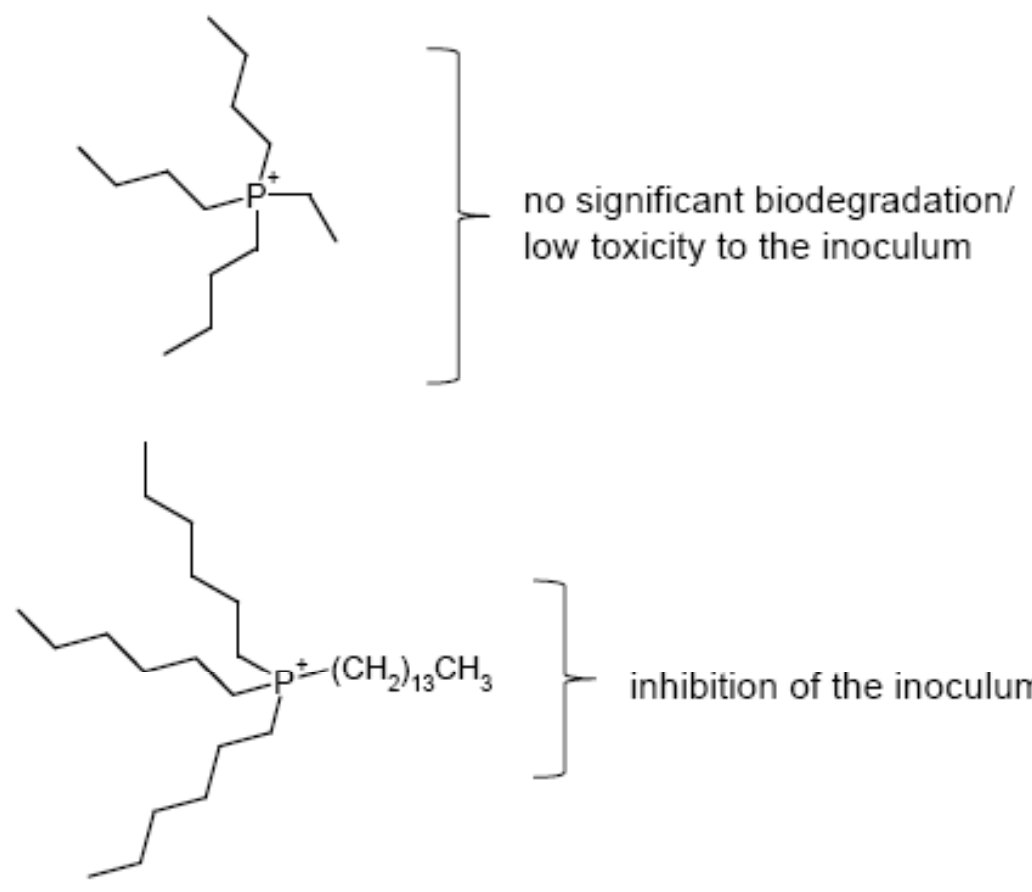

inhibition of the inoculum

Fig. (15). Biodegradability of P-substituted phosphonium compounds.

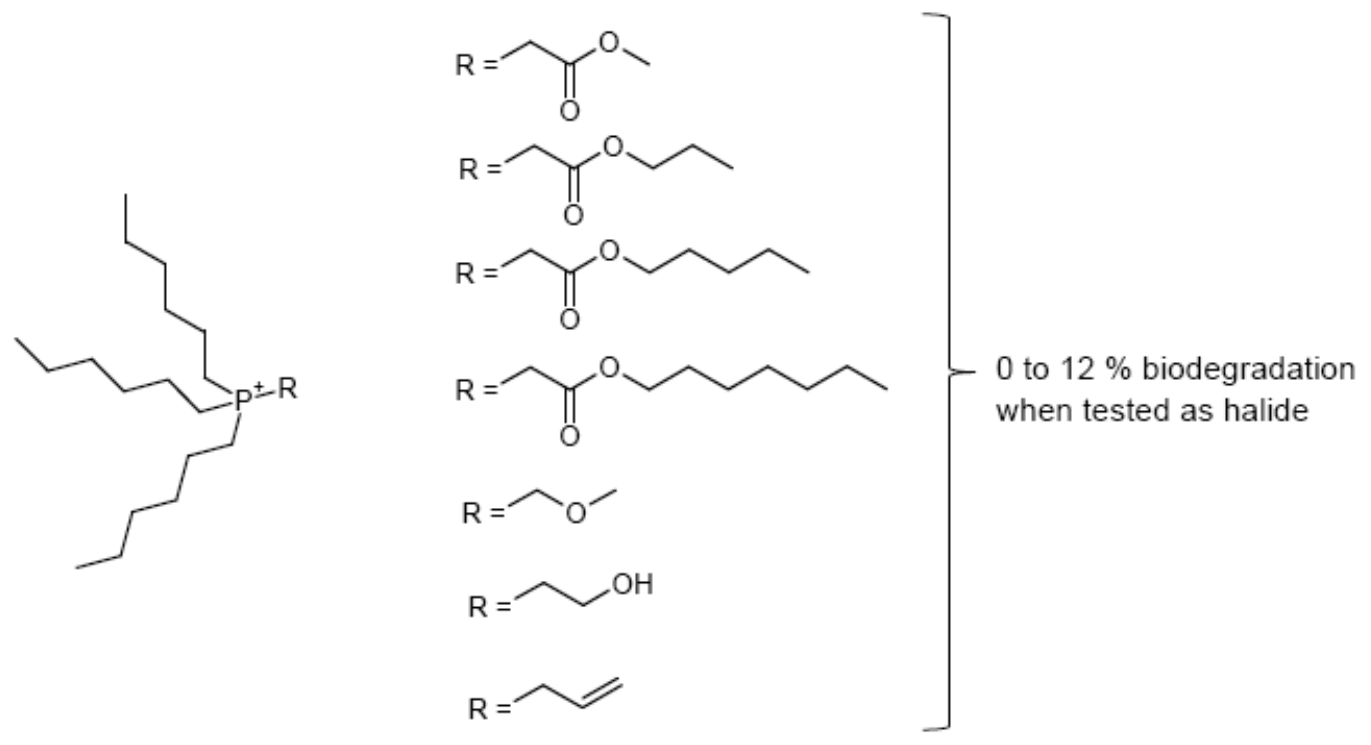

Fig. (16). Biodegradability of functionalized tri-n-hexyl phosphonium compounds.

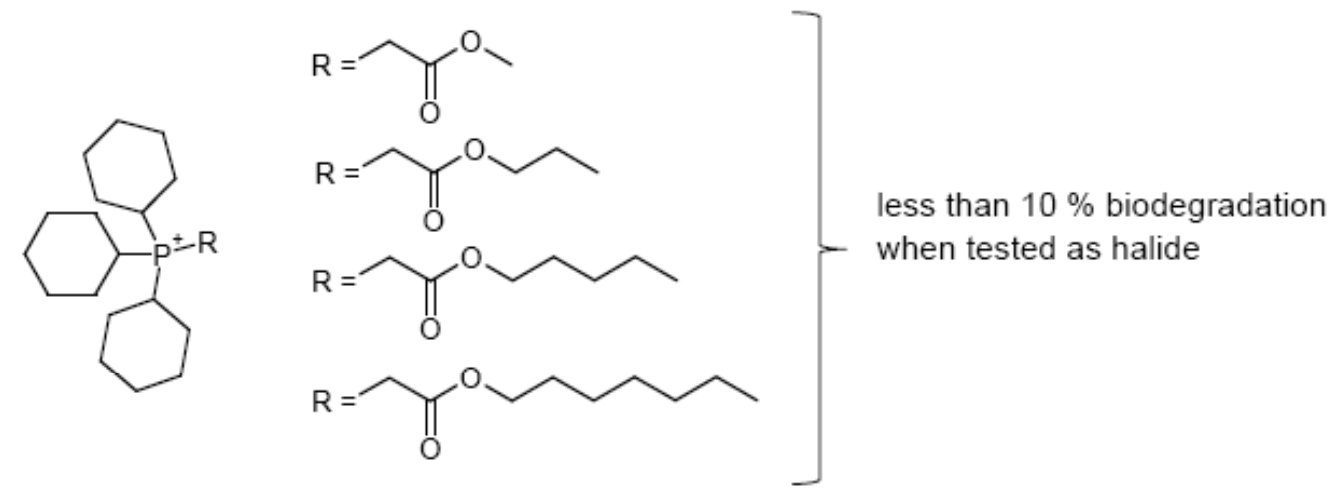

Fig. (17). Biodegradability of functionalized tricyclohexyl phosphonium compounds. 


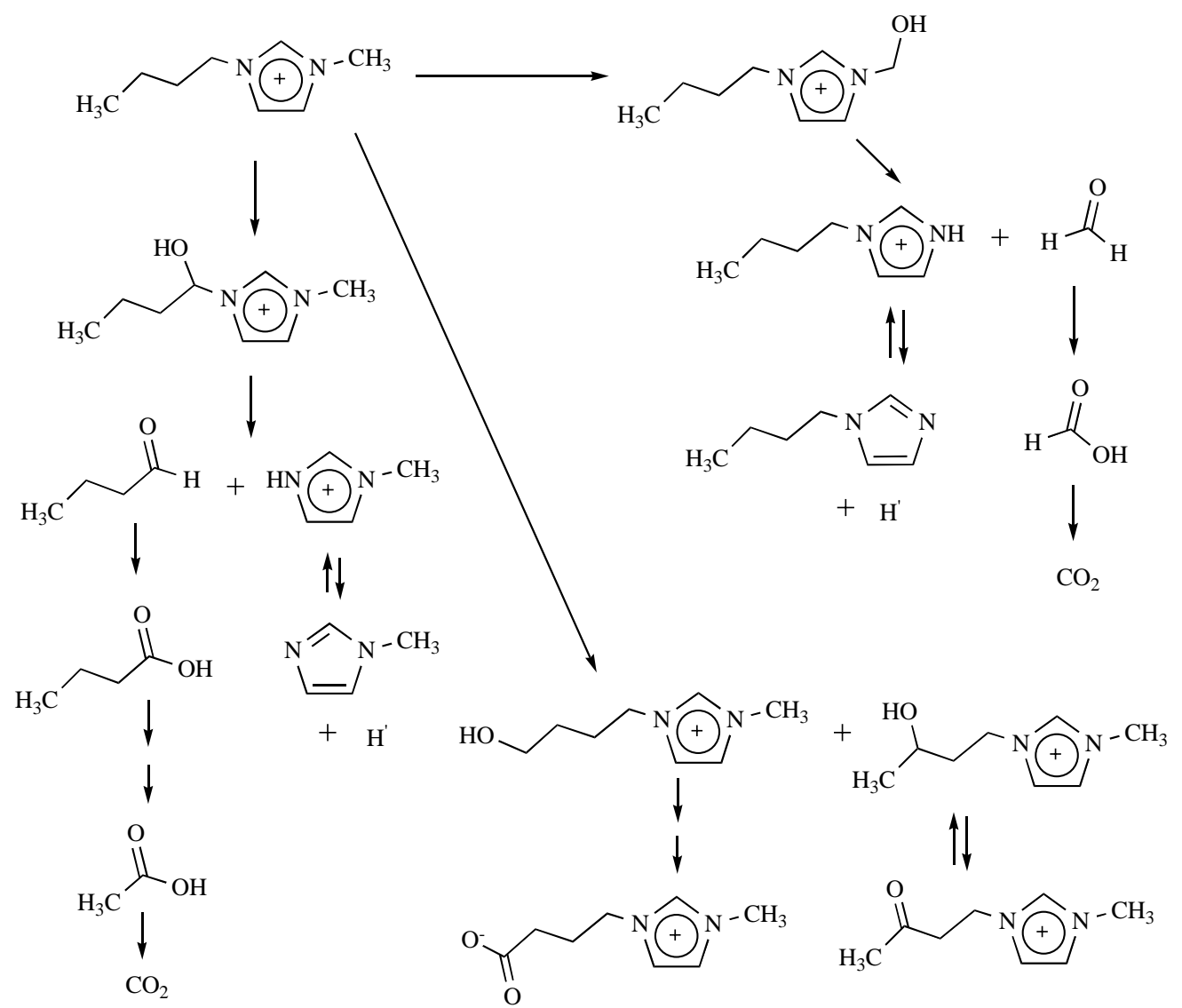

Fig. (18). Metabolites of IM14 predicted according to the T-SAR approach.

branched alkyl side chains (often C8 to C24) based on natural fats and oils (coconut, tallow fat or palm oil). Without going into the details of this very wide area, we now present some basic rules regarding biodegradability according to Van Ginkel [58]:

- alkyltrimethylammonium salts and benzylalkyldimethylammonium salts are better biodegradable than dialkyldimethylammonium cations;

- as the alkyl side chain becomes longer, its biodegradability drops (based on inhibitory effects);

- resistance to biodegradation is caused largely by increasing numbers of long alkyl side chains;

- ammonium salts with side chains containing ester and fatty acids are better biodegradable than ammonium salts with alkyl side chains.

In general, the use of ILs consisting of readily degradable natural ammonium cations, such as choline [45], can prevent recalcitrance to biodegradation.

To the best of our knowledge, no biodegradability data have yet been published for ILs based on other head groups like piperidinium, pyrrolidinium, morpholinium or quinolinium. However, Philipp et al. [51] used a large set of aerobic biodegradation data to establish rules for predicting the biodegradability of $\mathrm{N}$ heterocycles. These authors concluded that alkylation of the $\mathrm{N}$-atom of the ring generally reduces the biodegradability of $\mathrm{N}$ heterocycles. Even if this implies that not all $\mathrm{N}$-alkylated compounds are biodegradable (as in the case of pyridinium compounds), it is highly probable that structural modifications (like the introduction of oxo-groups into the ring or side chain modulation) are necessary to achieve biodegradable compounds.

\section{METABOLIC DEGRADATION PRODUCTS OF IONIC LIQUID CATIONS}

There are two reasons for investigating the nature of the biological conversion products of IL substructures. First of all, conversion pathways have to be known to avoid erroneous classifications of ILs if a pass level is fulfilled, but degradation products are recalcitrant toward biodegradation (see section "misleading interpretation of biodegradation data"). Secondly, knowledge of the chemical structure of the metabolites is crucial with respect to their hazard assessment. Metabolites have their own characteristic (eco)toxicological profiles and they may well be more toxic than their parent compound. Therefore, classical biodegradation protocols have to be linked to biodegradation studies.

\subsection{Imidazolium-based Cations}

Based on a theoretical approach named T-SAR (thinking in terms of structure activity relationships) [59] Jastorff et al. developed an algorithm for predicting the metabolites of the 3-butyl-1methyl-imidazolium cation (IM14) [60]. Several hydroxylated, carboxylated and dealkylated compounds were postulated (Fig. 18) and subsequently synthesized to assess their toxicity [61].

In a subsequent study the same group investigated the metabolic fate of compound IM18 via HPLC-MS analysis in a biodegradation experiment [18]. The identified degradation products were found to be generally in accordance with the postulated structures. The metabolites detected and the suggested breakdown pathway of IM18 are shown in Fig. (19). In general, the conversion of the alkyl chain seems to start with the oxidation of the terminal methyl group $(\omega$-oxidation), probably catalyzed by monooxygenases (for in- 


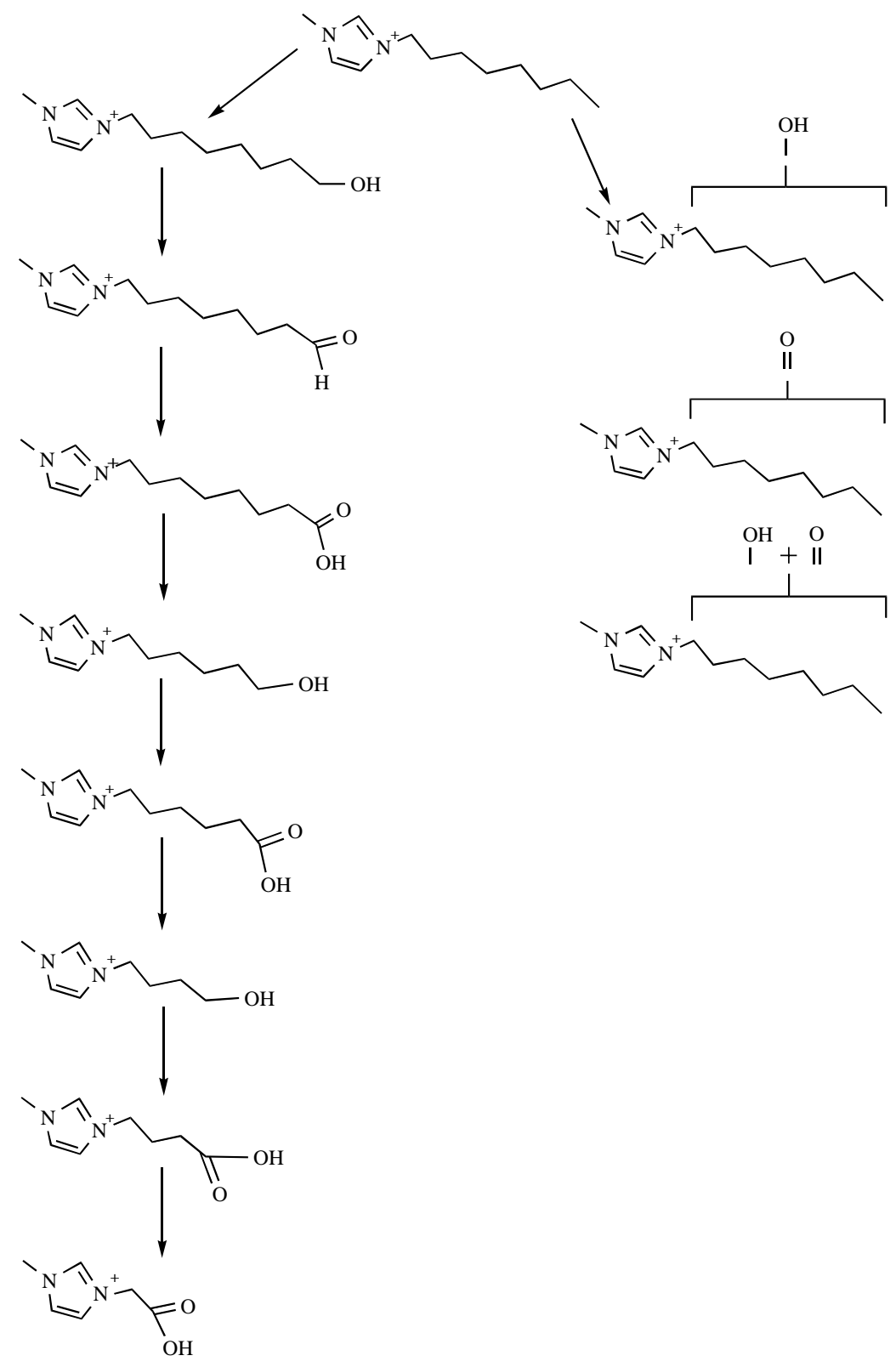

Fig. (19). Postulated chemical structures and degradation pathways of IM18. Reprinted with permission from Stolte et al. [18]. Copyright 2008 Royal Society of Chemistry.

stance, by the cytochrome P450 system). The remaining alcohol is subsequently oxidized by dehydrogenases via aldehydes to carboxylic acids. The resulting carboxylic acids can now undergo $\beta$ oxidation and the released two-carbon fragments can enter the tricarboxylic acid cycle via acetyl Co-A. The HPLC-MS results also indicate the formation of different non-terminal hydroxyl groups. These secondary alcohol isomers cannot be further degraded via $\beta$ oxidation. Their conversion ends either with the formation of ketones or additional hydroxylation steps [18].

In general, the identified conversion products of IM18 have shorter side chains and/or are functionalized. It is known from the literature that compounds with short, functionalized side chains are less toxic toward mammalian cells [14,61], marine bacteria, limnic green algae and duckweed, among other organisms [16]. Therefore, the conversion products present a lower hazard potential than the IM18 cation, which is highly toxic in water (especially to algae). Even so, some restrictions have to be made because the aldehydes, intermediates in the oxidation pathway from the $-\mathrm{CH}_{2} \mathrm{OH}$ group to the $-\mathrm{COOH}$ group, have not yet been analyzed regarding their (eco)toxicity; theoretically, the formation of highly reactive epoxides is also possible.

Docherty et al. [34] used ${ }^{1} \mathrm{H}$ - and ${ }^{13} \mathrm{C}$-NMR spectra to analyze initial and final biodegradation samples from different imidazolium ILs. A change in the chemical structures found in 3-hexyl-1methyl-imidazolium (IM16) and IM18, indicating a loss of four to five terminal $\mathrm{C}$-atoms from the side chain, while the ring structure of both compounds remained intact and was not used as a carbon source by the microorganisms.

\subsection{Pyridinium-Based Cations}

Biological conversion products were identified for an N-butyl3-methyl-pyridinium compound (Py4-3Me) by Pham et al. using liquid chromatography/mass spectrometry (LC-MS) [36]. After 28 


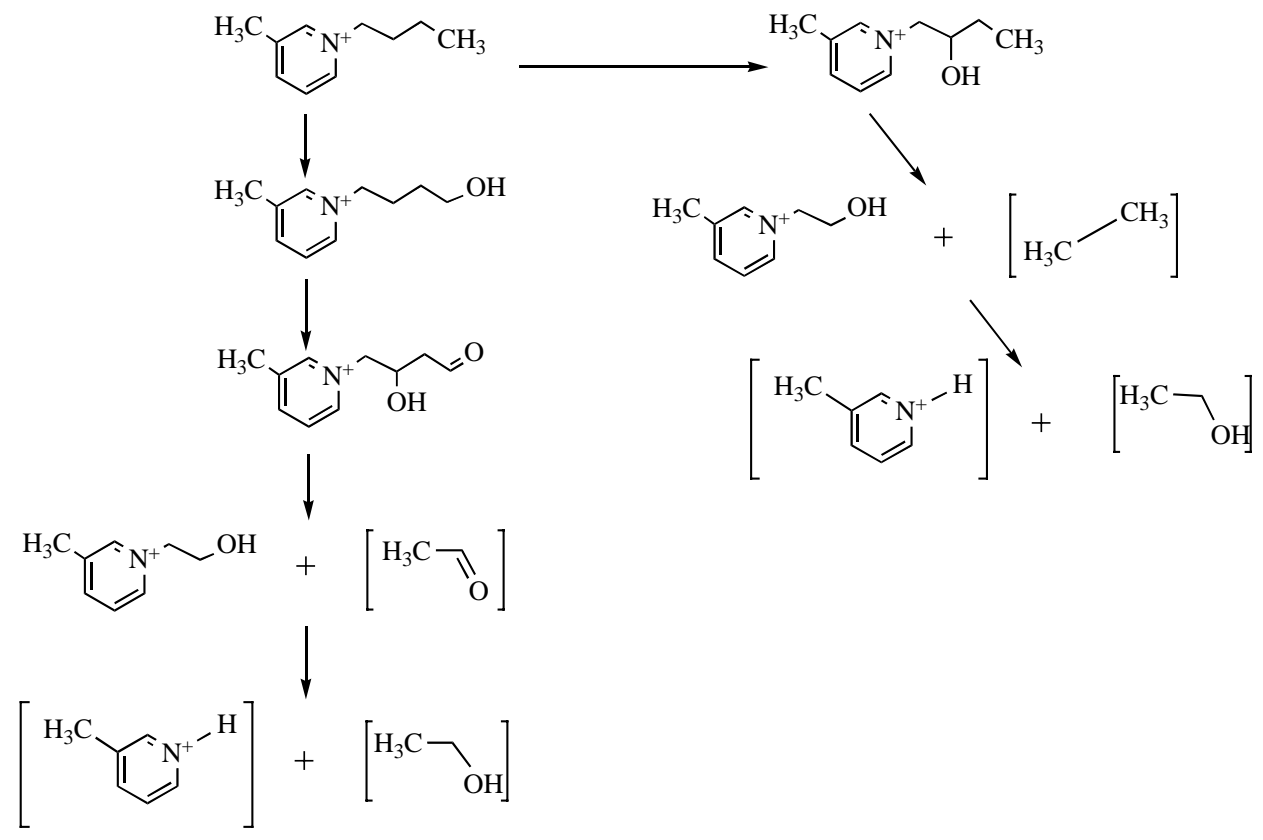

Fig. (20). Suggested chemical structures and degradation pathways of Py4-3Me. The intermediates shown in brackets were not detected or confirmed. Reprinted with permission of the American Chemical Society.

$$
\stackrel{\mathrm{N}^{+}}{\mathrm{N}^{+} \mathrm{Cl}^{-} \mathrm{IM} 12 \mathrm{Cl}}
$$

1-Ethyl-3-methylimidazolium chloride

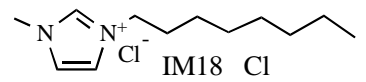

1-Octyl-3-methylimidazolium chloride

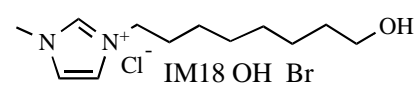

1-(8Hydroxyoct-3-methylimidazolium bromide

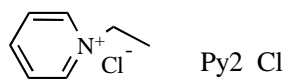

1-Ethylpyridinium chloride

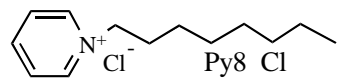

1-Octylpyridinium chloride

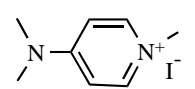

Py 14 NMe2 I

4-(Dimethylamin)e-3-methylpyridinium iodide

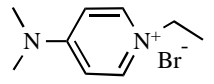

Py $24 \mathrm{NMe} 2 \mathrm{Br}$

4-(Dimethylamin)e-3-ethylpyridinium bromide

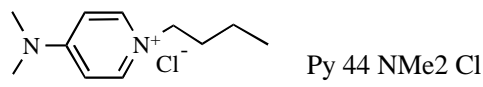

4-(Dimethylamin)e-3-ethylpyridinium chloride

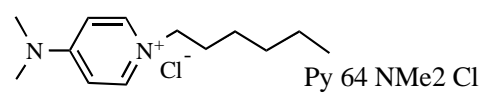

4-(Dimethylamin)e-3-exylpyridinium chloride

Fig. (21). Ionic liquids cation investigated under anaerobic conditions. Reprinted with permission from Neumann et al. [64]. Copyright 2009 Royal Society of Chemistry.

day of incubation with microorganisms from a wastewater treatment plant, single and double hydroxylation of the side chain could be detected, allowing the authors of this study to postulate two metabolic pathways (Fig. 20), both leading to the suggested (but not verified) formation of biodegradable 3-methylpyridine (Fig. 11).

Docherty et al. also identified 3-methylpyridine as a conversion product of the Py4-3Me cation, but in contrast to the findings of Pham et al., hydroxylation of the aromatic ring and not of the side chain took place. Moreover, this degradation involved the formation of a double bound within the butyl residue. Hydroxylation of both the side chain and the pyridinium core structure occurred in $\mathrm{N}$ hexyl-3-methyl-pyridinium (Py6-3Me), whereas just the side chain was oxidized in N-octyl-3-methyl-pyridinium (Py8-3Me).

Summing up, the results of the studies by Docherty et al. and Pham et al. suggest that different degradation pathways for one compound (here Py4-3Me) are possible depending on the microbial composition of the inocula, and that fundamentally different conversion pathways occur depending on the length of the alkyl chain.

\section{ANAEROBIC BIODEGRADABILITY AND CONVERSION OF IONIC LIQUID CATIONS}

All the data presented in the previous section were based on aerobic test conditions; nevertheless, anaerobic decomposition also plays an important role in reducing environmental concentrations of chemicals in, e.g., aquifers, eutrophic lakes, soils or sediments. Thus, investigating the breakdown of chemicals in the absence of oxygen has to be looked at in the context of the hazard assessment of compounds, especially as anaerobic degradation has already been shown to be successful for a range of substances that are recalcitrant to aerobic biodegradation. Examples are the anaerobic biodegradation of highly chlorinated hydrocarbons, such as tetrachloroethane (PCE) [62] and the reductive dechlorination of polychlorinated biphenyls (PCBs) in, e.g., sediments [63].

For ILs just one study was found that investigated the anaerobic biodegradation of IL cations under nitrogen-reducing conditions [64]. The primary degradation of different imidazolium, pyridinium and 4-(dimethylamino)pyridinium based cations (Fig. 21) was monitored via HPLC-MS over a period of 11 months. 


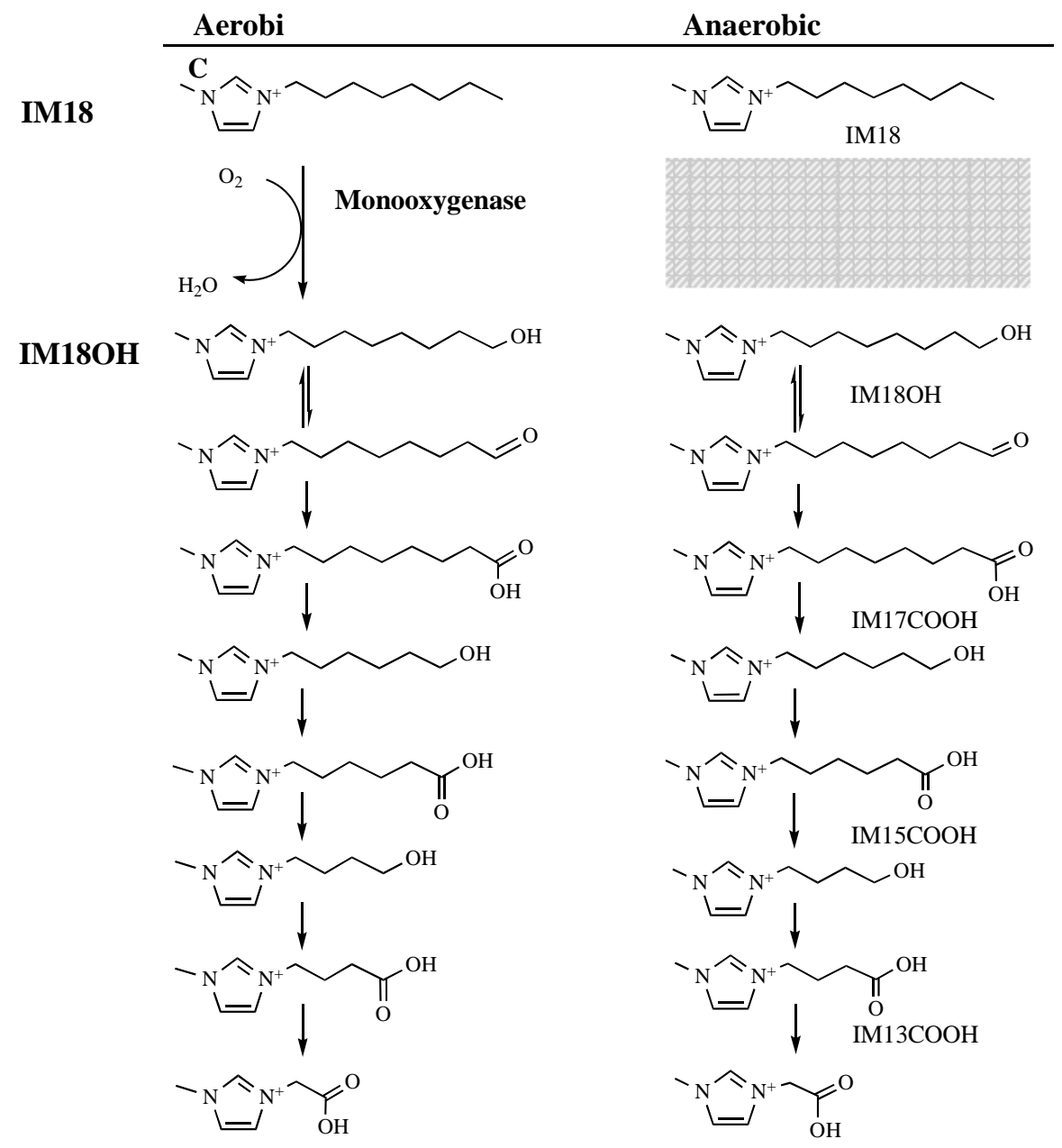

Fig. (22). Simplified scheme of the aerobic and anaerobic metabolic pathways suggested for IM18 and IM18OH. The chemical structures in black were found by MS measurements. The ones in gray are theoretical intermediates. Reprinted with permission from Neumann et al. [64]. Copyright 2009 Royal Society of Chemistry.

Only the 1-(8-hydroxyoctyl)-3-methylimidazolium cation (IM18OH) decomposed (by ca 50\% in 9 days and complete primary degradation after ca 40 days), whereas all other cations (including the IM18 cation) remained recalcitrant toward anaerobic degradation. Several metabolites of the IM18OH cation have been identified, which are similar to those found under aerobic conditions. Neumann et al. [64] reached the conclusion that in aerobic biodegradation processes, the initial oxidation of the octyl side chain of the IM18 cation probably involves molecular oxygen as a reactant (Fig. 22, left). The oxygen is inserted by monooxygenase and the alkyl side chain can be further degraded via ß-oxidation. Under anaerobic conditions, no molecular oxygen can be inserted by monooxygenase and biodegradation is not initiated (Fig. 22, right). In contrast, pre-oxygenated IM18OH can be biodegraded under anaerobic conditions. However, the present experiments do not imply the full mineralization of IM18OH, only a very slow biodegradation taking place under the experimental anaerobic conditions. Residual IM13COOH was still detected even after 10 months of the experiment. All in all, the biodegradability of the tested ILs seems to be even worse under anaerobic than under aerobic conditions.

\section{ABIOTIC DEGRADATION}

For a complete description of the environmental fate and the environmental lifetime of ionic liquid structures, abiotic transfor- mation processes also have to be considered. Abiotic mechanisms like oxidation, reduction, hydrolysis and photolysis represent important pathways for the degradation of man-made chemicals in the environment. The products formed by such abiotic conversions may be biodegraded further by microorganisms or are naturally found in the environment. For instance, the hydrolysis of $\left[\mathrm{BF}_{4}\right]^{-}$and $\left[\mathrm{PF}_{6}\right]^{-}$ results in the release of HF $[65,66]$. This acutely toxic [67] and corrosive compound is problematic with respect to operational safety and application in technical processes. In the context of (eco)toxicity and bioaccumulation, however, it is of minor concern, because the evolving compounds (fluoride, boric acid and phosphoric acid) are harmless to the environment in moderate concentrations. The hydrolysis data from the ionic liquid anions (C2F5)3PF3 and (CF2SO2) $2 \mathrm{~N}$ suggest that these anions are resistant to hydrolytic cleavage under environmental conditions. Generally, only a very limited data set on the abiotic conversion of IL cations and anions is available as yet. Photolysis may be the initial conversion step for non-biodegradable cations and anions, which then may lead to biodegradable conversion products.

\section{CONCLUSION}

It was the aim of this review to summarize, analyze and discuss IL biodegradation data with respect to structure-biodegradability relationships. The available data allow for a preliminary assessment 
of whether the $10^{\text {th }}$ principle of Green Chemistry (Design chemicals and products to degrade after use: Design chemical products to break down to innocuous substances after use so that they do not accumulate in the environment) is fulfilled for ionic liquid structures or not.

It has been shown that most ILs investigated so far cannot be classified as "readily biodegradable". Nevertheless, the structural design of ILs with substantially improved biodegradability has been found possible.

\subsection{Structural Attributes Influencing Biodegradability}

With respect to the structural design of ILs, increased biodegradability was observed in pyridinium, imidazolium and 4(dimethylamino)pyridinium cations with elongated alkyl side chains. It has been shown that a promising design criterion for achieving biodegradability is the introduction of ester functional groups into the side chains. With respect to the head group the pyridinium core generally exhibits a higher degree of biodegradation than imidazolium, 4-(dimethylamino)pyridinium or phosphonium head groups. In general, the pyridinium head group itself seems to be ultimately biodegradable, even when it is linked to shorter side chains (C4) and when the stringent, ready biodegradation test conditions are applied. In contrast, only the degradation of the side chain was observed in imidazolium compounds, the core structure remaining recalcitrant toward biodegradation under stringent conditions. However, the data derived from experiments with industrial inocula indicate that the imidazolium core can also be degraded under certain circumstances. For ILs represented by cationic and anionic structures it has to be considered that really biodegradable chemical structures have to be designed - hence, not only do the side chains but also the core structure of the head group and the anion have to be biodegradable. To achieve a biodegradable ionic liquid, a biodegradable cation has to be combined with an (a)biotically degradable anion. Here, different anions such as alkylsulfates (e.g., methylsulfate or octylsulfate), linear alkylsulfonates (e.g., methylsulfonate), linear alkylbenzene sulfonates (e.g., ptoluenesulfonate), and salts of organic acids (e.g., acetate or lactate) are recommendable with respect to their biodegradability as well as from an (eco)toxicological point of view. Typical fluorinecontaining ionic liquid anions $\left(\left[\left(\mathrm{CF}_{3} \mathrm{SO}_{2}\right)_{2} \mathrm{~N}\right]^{-}\right.$or $\left[\left(\mathrm{C}_{2} \mathrm{~F}_{5}\right)_{3} \mathrm{PF}_{3}\right]^{-}$ should be avoided when designing inherently safer ILs because these anions carry a high risk of being environmentally persistent and, on the basis of their substantial hydrophobicity, of accumulating in the tissues of living organisms.

\subsection{Biodegradability vs. (eco)toxicity}

The dependency between improved biodegradability and side chain length at any type of head group (so far investigated) creates a conflict of interests in the design process of inherently safer ILs: the shorter the alkyl side chain, the safer the chemical is with respect to (eco)toxicity issues, but the higher the risk of persistency and mobility owing to the lack of biodegradability and reduced sorption to organic matter and clay minerals. This conflict can be resolved to some extent if polar ester groups are linked to the cationic core.

A sound hazard assessment of chemicals will also take biological conversion products into consideration. Little information is available regarding this issue, however: most of the metabolites so far detected are the more polar ones, and the lower (eco)toxicity of these compounds has been postulated. Nevertheless, some restric- tions have to be imposed, because aldehydes, which are intermediates in the oxidation pathway from a terminal hydroxyl group to a carboxylic group, have not yet been analyzed for their (eco)toxicity. In principle, the formation of highly reactive epoxides is conceivable, especially during the observed hydroxylation step of the pyridinium core structure.

\subsection{Possible Reasons for Recalcitrance}

We assume that the interplay of environmental and structural factors is responsible for the recalcitrance of some ILs. In general the dependence between enhanced biodegradability and elongated side chains can be put down to the better diffusion of these compounds into the cell (making the compound accessible to enzymatic systems), but also to adaptation processes based on greater toxicity (based on selective pressure). A closer look at the pyridinium core, which is ultimately biodegradable even when bearing only short chain substituents, shows that enzymatic systems suitable for degrading this core are already present in some microorganisms, but depend on the source of the inoculum. This could be explained by the wide use and release of pyridine compounds (several highvolume production chemicals are pyridine-based) into the environment. Thus, if microorganisms are continuously exposed to those chemicals, it is increasingly likely that some microorganisms will adapt to this substrate. Also, it was found in imidazolium-based ILs that organisms exist which are capable of converting the core structure, though possibly only in certain areas, which may be exposed to higher concentrations of imidazole/imidazolium based compounds. The general ability of microorganisms to adapt to imidazolium and pyridinium compounds comes with a reduced risk of persistency of those ILs, but more detailed investigations are needed.

\subsection{Inherently Safe Chemicals vs. Technical Applicability}

The presented design criteria may lead to ILs with improved biodegradability, but they may also limit practical applications with respect to physicochemical properties such as stability (thermal or electrochemical) or viscosity. Therefore, for a particular technological application it may be necessary to use a non-biodegradable and/or (eco)toxic ionic liquid. The authors would like to point out that although these ILs can be components of sustainable products and processes, in such cases comprehensive risk management is needed with respect to the operational safety of employees. Furthermore, it has to be ensured that environmental contamination is minimal. Thus, within such processes strategies are demanded to remove these compounds, for instance, from processing effluents via regenerative methods (like membrane filtration [68]) or via destructive advanced oxidation techniques like electrochemical treatment [18] or UV degradation [69].

Finally, economic aspects and especially production costs will determine whether ILs will be used widely in technical applications. From a structural point of view they certainly have a considerable potential to contribute to the development of more sustainable products and processes.

\section{REMARKS AND OUTLOOK}

2 To acquire a valid data pool for the environmental hazard assessment of ILs, the very limited degradation data need to be complemented by data from abiotic degradation studies and by data from both aerobic and anaerobic biodegradation studies. In particular, systematic 
investigations to examine the biodegradability of different head groups are required. Additionally, more detailed knowledge of IL biodegradation pathways, kinetics and metabolites is desirable, as it would improve the hazard assessment of these chemicals.

3 The focus should not only be on the stringent "readily biodegradability test conditions", because most ILs are not readily biodegradable; it does not necessarily follow that they will not degrade in the environment. "Unconstrained" test conditions according to inherent biodegradation tests (under these conditions the imidazolium core was also found to be degradable) should be used to acquire general information about IL degradability in the environment.

4 The nature of the inoculum and its biodiversity (subject to spatial and temporal variations) was found to have a strong influence on the experimentally found biodegradation rates of ILs. The authors endorse the view of Docherty et al. that different inocula (from different sources, e.g., different wastewater treatment plants) should be incorporated into the standard biodegradability test procedure in order to obtain a wider range of microbial composition. Also, the identification of microorganisms capable of degrading compounds would be desirable for pollution prevention and for models predicting the environmental fate of man-made chemicals.

5 It has been shown that the interpretation of pass levels can lead to erroneous conclusions with respect to the design of non-persistent ILs. Ideally, ILs (and chemicals in general) should not be classified in this arbitrary manner. The aim of biodegradation experiments should not be to pass certain threshold values, but to find out whether a chemical or a combination of chemical entities and their first conversion products do or do not undergo further and rapid metabolization ending in complete biodegradation.

6 Recently, the "Ionic Liquids Biological Effects Database" (http://www.il-eco.uft.uni-bremen.de/) has been published. This freely accessible database provides information about biodegradation and (eco)toxicity of more than 300 different ionic liquids.

\section{ACKNOWLEDGEMENTS}

The authors gratefully thank Dr. Marianne Matzke, Dr. Jürgen Arning and Dr. Reinhold Störmann for helpful discussion. The authors would like to acknowledge the financial support of the European project MINILUBES (FP7 Marie Curie ITN network 216011-2) by the European Commission. This research was also supported by the German Federal Foundation for the Environment (Deutsche Bundesstiftung Umwelt (DBU), Osnabrück/Germany).

\section{APPENDIX}

10.1 Appendix A: Biodegradation data for imidazolium based ionic liquids

10.2 Appendix B: Biodegradation data for pyridinium based ionic liquids

10.2 Appendix C: Biodegradation data for ammonium and phosphonium compounds

Appendix A: Biodegradation Data for Imidazolium Based Ionic Liquids

\begin{tabular}{|c|c|c|c|c|c|c|c|c|c|c|c|}
\hline \multirow[t]{2}{*}{ Nr. } & \multicolumn{3}{|c|}{ Structure } & \multicolumn{2}{|c|}{ Results } & \multicolumn{5}{|c|}{ Test Conditions } & \multirow[t]{2}{*}{ Source } \\
\hline & Head Group & Side Chain & Anion & $\begin{array}{l}\text { Biodeg- } \\
\text { radation } \\
{[\%]}\end{array}$ & Classification & Guideline & Inoculum & $\begin{array}{l}\text { Substance } \\
\text { Concentration }\end{array}$ & $\begin{array}{l}\text { Duration } \\
\text { [d] }\end{array}$ & $\begin{array}{l}\text { Measured } \\
\text { Parameter }^{*}\end{array}$ & \\
\hline 1 & 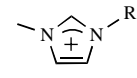 & $\mathrm{R}=-\mathrm{C}_{2} \mathrm{H}_{5}$ & $\mathrm{Cl}^{-}$ & 0 & $\begin{array}{l}\text { not readily } \\
\text { biodegradable }\end{array}$ & $\begin{array}{l}\text { modified } \\
\text { OECD } \\
\text { 301D Test }\end{array}$ & $\begin{array}{l}\text { activated } \\
\text { sludge }\end{array}$ & $200 \mu \mathrm{mol} / \mathrm{L}$ & 31 & $\begin{array}{l}\text { primary } \\
\text { biodegradation }\end{array}$ & [18] \\
\hline $2 a$ & & $\mathrm{R}=-\mathrm{C}_{4} \mathrm{H}_{9}$ & $\mathrm{Br}$ & 0 & $\begin{array}{l}\text { not readily } \\
\text { biodegradable }\end{array}$ & $\begin{array}{l}\text { "Die- } \\
\text { Away" Test } \\
\text { OECD } \\
\text { 301A }\end{array}$ & $\begin{array}{l}\text { activated } \\
\text { sludge }\end{array}$ & $40 \mathrm{mg} \mathrm{C} / \mathrm{L}$ & 43 & DOC & [34] \\
\hline $2 b$ & & $\mathrm{R}=-\mathrm{C}_{4} \mathrm{H}_{9}$ & $\mathrm{Br}^{\circ}$ & $<5$ & $\begin{array}{l}\text { not readily } \\
\text { biodegradable }\end{array}$ & $\begin{array}{l}\text { " } \mathrm{CO}_{2} \\
\text { headspace" } \\
\text { Test (ISO } \\
14593 \text { ) }\end{array}$ & $\begin{array}{l}\text { wastewater } \\
\text { organisms }\end{array}$ & $40 \mathrm{mg} / \mathrm{L}$ & 28 & TOC & [29] \\
\hline $2 \mathrm{c}$ & & $\mathrm{R}=-\mathrm{C}_{4} \mathrm{H}_{9}$ & $\mathrm{Br}^{-}$ & 1 & $\begin{array}{l}\text { not readily } \\
\text { biodegradable }\end{array}$ & $\begin{array}{l}\text { "Closed } \\
\text { Bottle" Test } \\
\text { (OECD } \\
\text { 301D) }\end{array}$ & $\begin{array}{l}\text { wastewater } \\
\text { organisms }\end{array}$ & $2 \mathrm{mg} / \mathrm{L}$ & 28 & BOD & [27] \\
\hline $2 \mathrm{~d}$ & & $\mathrm{R}=-\mathrm{C}_{4} \mathrm{H}_{9}$ & $\mathrm{Br}$ & $<5$ & $\begin{array}{l}\text { not readily } \\
\text { biodegradable }\end{array}$ & $\begin{array}{l}\text { "Closed } \\
\text { Bottle" Test } \\
\text { (OECD } \\
\text { 301D) }\end{array}$ & $\begin{array}{l}\text { wastewater } \\
\text { organisms }\end{array}$ & $2 \mathrm{mg} / \mathrm{L}$ & 28 & BOD & [28] \\
\hline $3 a$ & & $\mathrm{R}=-\mathrm{C}_{4} \mathrm{H}_{9}$ & $\mathrm{Cl}^{-}$ & 0 & $\begin{array}{l}\text { not readily } \\
\text { biodegradable }\end{array}$ & $\begin{array}{l}\text { modified } \\
\text { OECD } \\
\text { 301D Test }\end{array}$ & $\begin{array}{l}\text { activated } \\
\text { sludge }\end{array}$ & $200 \mu \mathrm{mol} / \mathrm{L}$ & 31 & $\begin{array}{l}\text { primary } \\
\text { biodegradation }\end{array}$ & [18] \\
\hline $3 b$ & & $\mathrm{R}=-\mathrm{C}_{4} \mathrm{H}_{9}$ & $\mathrm{Cl}^{-}$ & 0 & $\begin{array}{l}\text { not readily } \\
\text { biodegradable }\end{array}$ & $\begin{array}{l}\text { OECD } \\
301 \mathrm{~F}\end{array}$ & not specified & $100 \mathrm{mg} / \mathrm{L}$ & 28 & $\begin{array}{l}\text { BOD } \\
\text { COD }\end{array}$ & [17] \\
\hline $4 a$ & & $\mathrm{R}=-\mathrm{C}_{4} \mathrm{H}_{9}$ & $\mathrm{BF}_{4}^{-}$ & 0 & $\begin{array}{l}\text { not readily } \\
\text { biodegradable }\end{array}$ & $\begin{array}{l}\text { "Closed } \\
\text { Bottle" Test } \\
\text { (OECD } \\
\text { 301D) }\end{array}$ & $\begin{array}{l}\text { wastewater } \\
\text { organisms }\end{array}$ & $2 \mathrm{mg} / \mathrm{L}$ & 28 & BOD & [29] \\
\hline $4 b$ & & $\mathrm{R}=-\mathrm{C}_{4} \mathrm{H}_{9}$ & $\mathrm{BF}_{4}^{-}$ & $<5$ & $\begin{array}{l}\text { not readily } \\
\text { biodegradable }\end{array}$ & $\begin{array}{l}\text { "CO } \\
\text { headspace", } \\
\text { Test (ISO } \\
14593 \text { ) }\end{array}$ & $\begin{array}{l}\text { wastewater } \\
\text { organisms }\end{array}$ & $40 \mathrm{mg} / \mathrm{L}$ & 28 & TOC & [29] \\
\hline
\end{tabular}




\begin{tabular}{|c|c|c|c|c|c|c|c|c|c|c|}
\hline $4 \mathrm{c}$ & $\mathrm{R}=-\mathrm{C}_{4} \mathrm{H}_{9}$ & $\mathrm{BF}_{4}^{-}$ & 52 & $\begin{array}{l}\text { inherently biode- } \\
\text { gradable }\end{array}$ & $\begin{array}{l}\text { ASTM D D } \\
5988-96\end{array}$ & soil & $\begin{array}{l}0,5 \mathrm{~g} \text { ionic } \\
\text { liquid/300g soil }\end{array}$ & 180 & DOC & [39] \\
\hline $5 \mathrm{a}$ & $\mathrm{R}=-\mathrm{C}_{4} \mathrm{H}_{9}$ & $\mathrm{PF}_{6}^{-}$ & 0 & $\begin{array}{l}\text { not readily } \\
\text { biodegradable }\end{array}$ & $\begin{array}{l}\text { "Closed } \\
\text { Bottle" Test } \\
\text { (OECD } \\
\text { 301D) }\end{array}$ & $\begin{array}{l}\text { wastewater } \\
\text { organisms }\end{array}$ & $2 \mathrm{mg} / \mathrm{L}$ & 28 & BOD & [27] \\
\hline $5 b$ & $\mathrm{R}=-\mathrm{C}_{4} \mathrm{H}_{9}$ & $\mathrm{PF}_{6}{ }^{-}$ & 0 & $\begin{array}{l}\text { not readily } \\
\text { biodegradable }\end{array}$ & $\begin{array}{l}\text { OECD } \\
301 \mathrm{~F}\end{array}$ & not specified & $100 \mathrm{mg} / \mathrm{L}$ & 28 & $\begin{array}{l}\text { BOD } \\
\text { COD }\end{array}$ & [17] \\
\hline $5 c$ & $\mathrm{R}=-\mathrm{C}_{4} \mathrm{H}_{9}$ & $\mathrm{PF}_{6}$ & 60 & $\begin{array}{l}\text { not readily } \\
\text { biodegradable }\end{array}$ & $\begin{array}{l}\text { Modified } \\
\text { "Sturm" } \\
\text { test (OECD } \\
\text { 301B) }\end{array}$ & not specified & not specified & $\begin{array}{l}\text { not speci- } \\
\text { fied }\end{array}$ & not specified & [27] \\
\hline $6 a$ & $\mathrm{R}=-\mathrm{C}_{4} \mathrm{H}_{9}$ & $\mathrm{~N}(\mathrm{CN})_{2}^{-}$ & $<5$ & $\begin{array}{l}\text { not readily } \\
\text { biodegradable }\end{array}$ & $\begin{array}{l}\text { "Closed } \\
\text { Bottle" Test } \\
\text { (OECD } \\
\text { 301D) }\end{array}$ & $\begin{array}{l}\text { wastewater } \\
\text { organisms }\end{array}$ & $2 \mathrm{mg} / \mathrm{L}$ & 28 & BOD & [28] \\
\hline $6 \mathrm{~b}$ & $\mathrm{R}=-\mathrm{C}_{4} \mathrm{H}_{9}$ & $\mathrm{~N}(\mathrm{CN})_{2}^{-}$ & 17 & $\begin{array}{l}\text { inherently biode- } \\
\text { gradable }\end{array}$ & $\begin{array}{l}\text { ASTM D } \\
5988-96\end{array}$ & soil & $\begin{array}{l}0,5 \mathrm{~g} \text { ionic } \\
\text { liquid/300g soil }\end{array}$ & 180 & DOC & [39] \\
\hline 7 & $\mathrm{R}=-\mathrm{C}_{4} \mathrm{H}_{9}$ & $\begin{array}{l}\left(\mathrm{CF}_{3} \mathrm{SO}_{2}\right) \\
{ }_{2} \mathrm{~N}^{-}\end{array}$ & $<5$ & $\begin{array}{l}\text { not readily } \\
\text { biodegradable }\end{array}$ & $\begin{array}{l}\text { "Closed } \\
\text { Bottle" Test } \\
\text { (OECD } \\
\text { 301D) }\end{array}$ & $\begin{array}{l}\text { wastewater } \\
\text { organisms }\end{array}$ & $2 \mathrm{mg} / \mathrm{L}$ & 28 & BOD & [28] \\
\hline 8 & $\mathrm{R}=-\mathrm{C}_{4} \mathrm{H}_{9}$ & $\begin{array}{l}\mathrm{C}_{6} \mathrm{H}_{13} \mathrm{OS} \\
\mathrm{O}_{3}^{-}\end{array}$ & 34 & $\begin{array}{l}\text { inherently biode- } \\
\text { gradable }\end{array}$ & $\begin{array}{l}\text { " } \mathrm{CO}_{2} \\
\text { headspace", } \\
\text { Test (ISO } \\
14593)\end{array}$ & $\begin{array}{l}\text { activated } \\
\text { sludge }\end{array}$ & $40 \mathrm{mg} / \mathrm{L}$ & 28 & TOC & [31] \\
\hline 9 & $\mathrm{R}=-\mathrm{C}_{4} \mathrm{H}_{9}$ & $\begin{array}{l}\mathrm{C}_{7} \mathrm{H}_{15} \mathrm{OS} \\
\mathrm{O}_{3}^{-}\end{array}$ & 36 & $\begin{array}{l}\text { inherently biode- } \\
\text { gradable }\end{array}$ & $\begin{array}{l}\text { " } \mathrm{CO}_{2} \\
\text { headspace" } \\
\text { Test (ISO } \\
14593 \text { ) }\end{array}$ & $\begin{array}{l}\text { activated } \\
\text { sludge }\end{array}$ & $40 \mathrm{mg} / \mathrm{L}$ & 28 & TOC & [31] \\
\hline $10 \mathrm{a}$ & $\mathrm{R}=-\mathrm{C}_{4} \mathrm{H}_{9}$ & $\begin{array}{l}\mathrm{C}_{8} \mathrm{H}_{17} \mathrm{OS} \\
\mathrm{O}_{3}^{-}\end{array}$ & 25 & $\begin{array}{l}\text { not readily } \\
\text { biodegradable }\end{array}$ & $\begin{array}{l}\text { "Closed } \\
\text { Bottle" Test } \\
\text { (OECD } \\
\text { 301D) }\end{array}$ & $\begin{array}{l}\text { wastewater } \\
\text { organisms }\end{array}$ & $2 \mathrm{mg} / \mathrm{L}$ & 28 & BOD & [28] \\
\hline $10 \mathrm{~b}$ & $\mathrm{R}=-\mathrm{C}_{4} \mathrm{H}_{9}$ & $\begin{array}{l}\mathrm{C}_{8} \mathrm{H}_{17} \mathrm{OS} \\
\mathrm{O}_{3}^{-}\end{array}$ & 40 & $\begin{array}{l}\text { not readily } \\
\text { biodegradable }\end{array}$ & $\begin{array}{l}\text { " } \mathrm{CO}_{2} \\
\text { headspace" } \\
\text { Test (ISO } \\
14593)\end{array}$ & $\begin{array}{l}\text { activated } \\
\text { sludge }\end{array}$ & $40 \mathrm{mg} / \mathrm{L}$ & 28 & TOC & [31] \\
\hline 11 & $\mathrm{R}=-\mathrm{C}_{4} \mathrm{H}_{9}$ & $\begin{array}{l}\mathrm{C}_{9} \mathrm{H}_{19} \mathrm{OS} \\
\mathrm{O}_{3}^{-}\end{array}$ & 47 & $\begin{array}{l}\text { not readily } \\
\text { biodegradable }\end{array}$ & $\begin{array}{l}\text { " } \mathrm{CO}_{2} \\
\text { headspace" } \\
\text { Test (ISO } \\
\text { 14593) }\end{array}$ & $\begin{array}{l}\text { activated } \\
\text { sludge }\end{array}$ & $40 \mathrm{mg} / \mathrm{L}$ & 28 & TOC & [31] \\
\hline 12 & $\mathrm{R}=-\mathrm{C}_{4} \mathrm{H}_{9}$ & $\begin{array}{l}\mathrm{C}_{10} \mathrm{H}_{21} \mathrm{OS} \\
\mathrm{O}_{3}^{-}\end{array}$ & 54 & $\begin{array}{l}\text { not readily } \\
\text { biodegradable }\end{array}$ & $\begin{array}{l}\text { "'CO} \mathrm{CO}_{2} \\
\text { headspace" } \\
\text { Test (ISO } \\
14593 \text { ) }\end{array}$ & $\begin{array}{l}\text { activated } \\
\text { sludge }\end{array}$ & $40 \mathrm{mg} / \mathrm{L}$ & 28 & TOC & [31] \\
\hline 13 & $\mathrm{R}=-\mathrm{C}_{4} \mathrm{H}_{9}$ & $\begin{array}{l}\mathrm{C}_{12} \mathrm{H}_{25} \mathrm{OS} \\
\mathrm{O}_{3}^{-}\end{array}$ & 58 & $\begin{array}{l}\text { not readily } \\
\text { biodegradable }\end{array}$ & $\begin{array}{l}\text { " } \mathrm{CO}_{2} \\
\text { headspace" } \\
\text { Test (ISO } \\
14593 \text { ) }\end{array}$ & $\begin{array}{l}\text { activated } \\
\text { sludge }\end{array}$ & $40 \mathrm{mg} / \mathrm{L}$ & 28 & TOC & [31] \\
\hline 14 & $\mathrm{R}=-\mathrm{C}_{4} \mathrm{H}_{9}$ & $\mathrm{CH}_{3} \mathrm{SO}_{3}^{-}$ & 8 & $\begin{array}{l}\text { not readily } \\
\text { biodegradable }\end{array}$ & $\begin{array}{l}\text { " } \mathrm{CO}_{2} \\
\text { headspace" } \\
\text { Test (ISO } \\
14593)\end{array}$ & $\begin{array}{l}\text { activated } \\
\text { sludge }\end{array}$ & $40 \mathrm{mg} / \mathrm{L}$ & 28 & TOC & [31] \\
\hline 15 & $\mathrm{R}=-\mathrm{C}_{4} \mathrm{H}_{9}$ & lactate & 17 & $\begin{array}{l}\text { not readily } \\
\text { biodegradable }\end{array}$ & $\begin{array}{l}\text { " } \mathrm{CO}_{2} \\
\text { headspace" } \\
\text { Test (ISO } \\
14593 \text { ) }\end{array}$ & $\begin{array}{l}\text { activated } \\
\text { sludge }\end{array}$ & $40 \mathrm{mg} / \mathrm{L}$ & 28 & TOC & [31] \\
\hline 16 & $\mathrm{R}=-\mathrm{C}_{4} \mathrm{H}_{9}$ & $\begin{array}{l}\left(\mathrm{C}_{4} \mathrm{H}_{9} \mathrm{O}\right)_{2} \\
\mathrm{PO}_{2}^{-}\end{array}$ & 5 & $\begin{array}{l}\text { not readily } \\
\text { biodegradable }\end{array}$ & $\begin{array}{l}\text { " } \mathrm{CO}_{2} \\
\text { headspace" } \\
\text { Test (ISO } \\
14593)\end{array}$ & $\begin{array}{l}\text { activated } \\
\text { sludge }\end{array}$ & $40 \mathrm{mg} / \mathrm{L}$ & 28 & TOC & [31] \\
\hline 17 & $\mathrm{R}=-\mathrm{C}_{4} \mathrm{H}_{9}$ & $\begin{array}{l}\text { sacchari- } \\
\text { nate }\end{array}$ & 41 & $\begin{array}{l}\text { not readily } \\
\text { biodegradable }\end{array}$ & $\begin{array}{l}\text { "'CO } \\
\text { headspace" } \\
\text { Test (ISO } \\
14593 \text { ) }\end{array}$ & $\begin{array}{l}\text { activated } \\
\text { sludge }\end{array}$ & $40 \mathrm{mg} / \mathrm{L}$ & 28 & TOC & [31] \\
\hline 18 & $\mathrm{R}=-\mathrm{C}_{6} \mathrm{H}_{13}$ & $\mathrm{Cl}^{-}$ & 11 & $\begin{array}{l}\text { not readily } \\
\text { biodegradable }\end{array}$ & $\begin{array}{l}\text { modified } \\
\text { OECD } \\
\text { 301D Test }\end{array}$ & $\begin{array}{l}\text { activated } \\
\text { sludge }\end{array}$ & $200 \mu \mathrm{mol} / \mathrm{L}$ & 31 & $\begin{array}{l}\text { primary } \\
\text { biodegradation }\end{array}$ & [18] \\
\hline 19 & $\mathrm{R}=-\mathrm{C}_{6} \mathrm{H}_{13}$ & $\mathrm{Br}^{-}$ & 54 & $\begin{array}{l}\text { not readily } \\
\text { biodegradable; } \\
\text { partially } \\
\text { mineralised }\end{array}$ & $\begin{array}{l}\text { "Die- } \\
\text { Away" Test } \\
\text { OECD } \\
\text { 301A }\end{array}$ & $\begin{array}{l}\text { activated } \\
\text { sludge }\end{array}$ & $40 \mathrm{mg} \mathrm{C} / \mathrm{L}$ & 37 & DOC & [34] \\
\hline 20 & $\mathrm{R}=-\mathrm{C}_{6} \mathrm{H}_{13}$ & $\begin{array}{l}\mathrm{C}_{6} \mathrm{H}_{13} \mathrm{OS} \\
\mathrm{O}_{3}^{-}\end{array}$ & 30 & $\begin{array}{l}\text { not readily } \\
\text { biodegradable }\end{array}$ & $\begin{array}{l}\text { " } \mathrm{CO}_{2} \\
\text { headspace" } \\
\text { Test (ISO } \\
14593)\end{array}$ & $\begin{array}{l}\text { activated } \\
\text { sludge }\end{array}$ & $40 \mathrm{mg} / \mathrm{L}$ & 28 & TOC & [31] \\
\hline 21 & $\mathrm{R}=-\mathrm{C}_{6} \mathrm{H}_{13}$ & $\begin{array}{l}\mathrm{C}_{7} \mathrm{H}_{15} \mathrm{OS} \\
\mathrm{O}_{3}^{-}\end{array}$ & 33 & $\begin{array}{l}\text { not readily } \\
\text { biodegradable }\end{array}$ & $\begin{array}{l}\text { " } \mathrm{CO}_{2} \\
\text { headspace" } \\
\text { Test (ISO } \\
14593)\end{array}$ & $\begin{array}{l}\text { activated } \\
\text { sludge }\end{array}$ & $40 \mathrm{mg} / \mathrm{L}$ & 28 & TOC & [31] \\
\hline 22 & $\mathrm{R}=-\mathrm{C}_{6} \mathrm{H}_{13}$ & $\begin{array}{l}\mathrm{C}_{8} \mathrm{H}_{17} \mathrm{OS} \\
\mathrm{O}_{3}^{-}\end{array}$ & 38 & $\begin{array}{l}\text { not readily } \\
\text { biodegradable }\end{array}$ & $\begin{array}{l}\text { " } \mathrm{CO}_{2} \\
\text { headspace", } \\
\text { Test (ISO } \\
14593 \text { ) }\end{array}$ & $\begin{array}{l}\text { activated } \\
\text { sludge }\end{array}$ & $40 \mathrm{mg} / \mathrm{L}$ & 28 & TOC & [31] \\
\hline
\end{tabular}




\begin{tabular}{|c|c|c|c|c|c|c|c|c|c|c|}
\hline 23 & $\mathrm{R}=-\mathrm{C}_{6} \mathrm{H}_{13}$ & $\begin{array}{l}\mathrm{C}_{9} \mathrm{H}_{19} \mathrm{OS} \\
\mathrm{O}_{3}^{-}\end{array}$ & 36 & $\begin{array}{l}\text { not readily } \\
\text { biodegradable }\end{array}$ & $\begin{array}{l}\text { "'CO } \\
\text { headspace" } \\
\text { Test (ISO } \\
14593 \text { ) }\end{array}$ & $\begin{array}{l}\text { activated } \\
\text { sludge }\end{array}$ & $40 \mathrm{mg} / \mathrm{L}$ & 28 & TOC & [31] \\
\hline 24 & $\mathrm{R}=-\mathrm{C}_{6} \mathrm{H}_{13}$ & $\begin{array}{l}\mathrm{C}_{10} \mathrm{H}_{21} \mathrm{OS} \\
\mathrm{O}_{3}\end{array}$ & 44 & $\begin{array}{l}\text { not readily } \\
\text { biodegradable }\end{array}$ & $\begin{array}{l}\text { " } \mathrm{CO}_{2} \\
\text { headspace" } \\
\text { Test (ISO } \\
14593 \text { ) }\end{array}$ & $\begin{array}{l}\text { activated } \\
\text { sludge }\end{array}$ & $40 \mathrm{mg} / \mathrm{L}$ & 28 & TOC & [31] \\
\hline 25 & $\mathrm{R}=-\mathrm{C}_{6} \mathrm{H}_{13}$ & $\begin{array}{l}\mathrm{C}_{12} \mathrm{H}_{25} \mathrm{OS} \\
\mathrm{O}_{3}^{-}\end{array}$ & 49 & $\begin{array}{l}\text { not readily } \\
\text { biodegradable }\end{array}$ & $\begin{array}{l}\text { " } \mathrm{CO}_{2} \\
\text { headspace" } \\
\text { Test (ISO } \\
14593 \text { ) }\end{array}$ & $\begin{array}{l}\text { activated } \\
\text { sludge }\end{array}$ & $40 \mathrm{mg} / \mathrm{L}$ & 28 & TOC & [31] \\
\hline 26 & $\mathrm{R}=-\mathrm{C}_{8} \mathrm{H}_{17}$ & $\mathrm{Cl}^{-}$ & 100 & $\begin{array}{l}\text { inherently biode- } \\
\text { gradable }\end{array}$ & $\begin{array}{l}\text { modified } \\
\text { OECD } \\
\text { 301D Test }\end{array}$ & $\begin{array}{l}\text { activated } \\
\text { sludge }\end{array}$ & $200 \mu \mathrm{mol} / \mathrm{L}$ & 31 & $\begin{array}{l}\text { primary } \\
\text { biodegradation }\end{array}$ & [18] \\
\hline 27 & $\mathrm{R}=-\mathrm{C}_{8} \mathrm{H}_{17}$ & $\mathrm{Br}^{-}$ & 41 & $\begin{array}{l}\text { not readily } \\
\text { biodegradable; } \\
\text { partially } \\
\text { mineralised }\end{array}$ & $\begin{array}{l}\text { "Die- } \\
\text { Away" Test } \\
\text { OECD } \\
\text { 301A }\end{array}$ & $\begin{array}{l}\text { activated } \\
\text { sludge }\end{array}$ & $40 \mathrm{mg} \mathrm{C} / \mathrm{L}$ & 38 & DOC & [34] \\
\hline 28 & $\begin{array}{l}\mathrm{R}= \\
\mathrm{CH}_{3} \mathrm{CH}_{2}=\mathrm{CH}_{2}\end{array}$ & $\mathrm{Br}^{-}$ & $<5$ & $\begin{array}{l}\text { not readily } \\
\text { biodegradable }\end{array}$ & $\begin{array}{l}\text { " } \mathrm{CO}_{2} \\
\text { headspace" } \\
\text { Test (ISO } \\
14593 \text { ) }\end{array}$ & $\begin{array}{l}\text { activated } \\
\text { sludge }\end{array}$ & $40 \mathrm{mg} / \mathrm{L}$ & 28 & TOC & [31] \\
\hline 29 & $\begin{array}{l}\mathrm{R}= \\
\mathrm{CH}_{3} \mathrm{CH}_{2}=\mathrm{CH}_{2}\end{array}$ & $\begin{array}{l}\mathrm{C}_{8} \mathrm{H}_{17} \mathrm{OS} \\
\mathrm{O}_{3}^{-}\end{array}$ & 43 & $\begin{array}{l}\text { not readily } \\
\text { biodegradable }\end{array}$ & $\begin{array}{l}\text { " } \mathrm{CO}_{2} \\
\text { headspace" } \\
\text { Test (ISO } \\
14593)\end{array}$ & $\begin{array}{l}\text { activated } \\
\text { sludge }\end{array}$ & $40 \mathrm{mg} / \mathrm{L}$ & 28 & TOC & [31] \\
\hline 30 & $\mathrm{R}=-\mathrm{CH}_{3} \mathrm{CN}$ & $\mathrm{Cl}^{-}$ & 0 & $\begin{array}{l}\text { not readily } \\
\text { biodegradable }\end{array}$ & $\begin{array}{l}\text { modified } \\
\text { OECD } \\
\text { 301D Test }\end{array}$ & $\begin{array}{l}\text { activated } \\
\text { sludge }\end{array}$ & $200 \mu \mathrm{mol} / \mathrm{L}$ & 31 & $\begin{array}{l}\text { primary } \\
\text { biodegradation }\end{array}$ & [18] \\
\hline 31 & $\mathrm{R}=-\mathrm{C}_{2} \mathrm{H}_{4} \mathrm{OH}$ & $\mathrm{I}^{-}$ & 0 & $\begin{array}{l}\text { not readily } \\
\text { biodegradable }\end{array}$ & $\begin{array}{l}\text { modified } \\
\text { OECD } \\
\text { 301D Test }\end{array}$ & $\begin{array}{l}\text { activated } \\
\text { sludge }\end{array}$ & $200 \mu \mathrm{mol} / \mathrm{L}$ & 31 & $\begin{array}{l}\text { primary } \\
\text { biodegradation }\end{array}$ & [18] \\
\hline 32 & $\mathrm{R}=-\mathrm{C}_{2} \mathrm{H}_{4} \mathrm{OH}$ & $\mathrm{Br}^{-}$ & $<5$ & $\begin{array}{l}\text { not readily } \\
\text { biodegradable }\end{array}$ & $\begin{array}{l}\text { " } \mathrm{CO}_{2} \\
\text { headspace" } \\
\text { Test (ISO } \\
14593)\end{array}$ & $\begin{array}{l}\text { activated } \\
\text { sludge }\end{array}$ & $40 \mathrm{mg} / \mathrm{L}$ & 28 & TOC & [31] \\
\hline 33 & $\mathrm{R}=-\mathrm{C}_{3} \mathrm{H}_{6} \mathrm{OH}$ & $\mathrm{Cl}^{-}$ & 0 & $\begin{array}{l}\text { not readily } \\
\text { biodegradable }\end{array}$ & $\begin{array}{l}\text { modified } \\
\text { OECD } \\
\text { 301D Test }\end{array}$ & $\begin{array}{l}\text { activated } \\
\text { sludge }\end{array}$ & $200 \mu \mathrm{mol} / \mathrm{L}$ & 31 & $\begin{array}{l}\text { primary } \\
\text { biodegradation }\end{array}$ & [18] \\
\hline 34 & $\mathrm{R}=-\mathrm{C}_{8} \mathrm{H}_{16} \mathrm{OH}$ & $\mathrm{Br}^{-}$ & 100 & $\begin{array}{l}\text { inherently biode- } \\
\text { gradable }\end{array}$ & $\begin{array}{l}\text { modified } \\
\text { OECD } \\
\text { 301D Test }\end{array}$ & $\begin{array}{l}\text { activated } \\
\text { sludge }\end{array}$ & $200 \mu \mathrm{mol} / \mathrm{L}$ & 31 & $\begin{array}{l}\text { primary } \\
\text { biodegradation }\end{array}$ & [18] \\
\hline 35 & $\begin{array}{l}\mathrm{R}= \\
\mathrm{C}_{7} \mathrm{H}_{14} \mathrm{COOH}\end{array}$ & $\mathrm{Br}$ & 100 & $\begin{array}{l}\text { inherently biode- } \\
\text { gradable }\end{array}$ & $\begin{array}{l}\text { modified } \\
\text { OECD } \\
\text { 301D Test }\end{array}$ & $\begin{array}{l}\text { activated } \\
\text { sludge }\end{array}$ & $200 \mu \mathrm{mol} / \mathrm{L}$ & 31 & $\begin{array}{l}\text { primary } \\
\text { biodegradation }\end{array}$ & [18] \\
\hline 36 & $\begin{array}{l}\mathrm{R}= \\
\mathrm{C}_{4} \mathrm{H}_{8} \mathrm{OC}(\mathrm{O}) \mathrm{C}^{-} \\
\mathrm{H}_{3}\end{array}$ & $\mathrm{I}^{-}$ & 25 & $\begin{array}{l}\text { not readily } \\
\text { biodegradable }\end{array}$ & $\begin{array}{l}\text { " } \mathrm{CO}_{2} \\
\text { headspace" } \\
\text { Test (ISO } \\
14593 \text { ) }\end{array}$ & $\begin{array}{l}\text { activated } \\
\text { sludge }\end{array}$ & $40 \mathrm{mg} / \mathrm{L}$ & 28 & TOC & [31] \\
\hline 37 & $\begin{array}{l}\mathrm{R}= \\
\mathrm{C}_{4} \mathrm{H}_{8} \mathrm{OC}(\mathrm{O}) \mathrm{C} \\
\mathrm{H}_{3}\end{array}$ & $\begin{array}{l}\mathrm{C}_{8} \mathrm{H}_{17} \mathrm{OS} \\
\mathrm{O}_{3}^{-}\end{array}$ & 54 & $\begin{array}{l}\text { not readily } \\
\text { biodegradable }\end{array}$ & $\begin{array}{l}\text { " } \mathrm{CO}_{2} \\
\text { headspace" } \\
\text { Test (ISO } \\
14593)\end{array}$ & $\begin{array}{l}\text { activated } \\
\text { sludge }\end{array}$ & $40 \mathrm{mg} / \mathrm{L}$ & 28 & TOC & [31] \\
\hline 38 & $\begin{array}{l}\mathrm{R}= \\
\mathrm{CH}_{2} \mathrm{OC}_{2} \mathrm{H}_{5}\end{array}$ & $\mathrm{Cl}^{-}$ & 0 & $\begin{array}{l}\text { not readily } \\
\text { biodegradable }\end{array}$ & $\begin{array}{l}\text { modified } \\
\text { OECD } \\
\text { 301D Test }\end{array}$ & $\begin{array}{l}\text { activated } \\
\text { sludge }\end{array}$ & $200 \mu \mathrm{mol} / \mathrm{L}$ & 31 & $\begin{array}{l}\text { primary } \\
\text { biodegradation }\end{array}$ & [18] \\
\hline 39 & $\begin{array}{l}\mathrm{R}= \\
\mathrm{C}_{2} \mathrm{H}_{5} \mathrm{OCH}_{3}\end{array}$ & $\mathrm{Cl}^{-}$ & 0 & $\begin{array}{l}\text { not readily } \\
\text { biodegradable }\end{array}$ & $\begin{array}{l}\text { modified } \\
\text { OECD } \\
\text { 301D Test }\end{array}$ & $\begin{array}{l}\text { activated } \\
\text { sludge }\end{array}$ & $200 \mu \mathrm{mol} / \mathrm{L}$ & 31 & $\begin{array}{l}\text { primary } \\
\text { biodegradation }\end{array}$ & [18] \\
\hline 40 & $\begin{array}{l}\mathrm{R}= \\
\mathrm{C}_{2} \mathrm{H}_{5} \mathrm{OCH}_{3}\end{array}$ & $\mathrm{BF}_{4}^{-}$ & 4 & $\begin{array}{l}\text { not readily } \\
\text { biodegradable }\end{array}$ & $\begin{array}{ll}\text { ASTM } & \text { D } \\
5988-96 & \end{array}$ & soil & $\begin{array}{l}0,5 \mathrm{~g} \quad \text { ionic } \\
\text { liquid/300g soil }\end{array}$ & 180 & DOC & [39] \\
\hline 41 & $\begin{array}{l}\mathrm{R}= \\
\mathrm{C}_{2} \mathrm{H}_{5} \mathrm{OCH}_{3}\end{array}$ & $\mathrm{~N}(\mathrm{CN})_{2}^{-}$ & 0 & $\begin{array}{l}\text { not readily } \\
\text { biodegradable }\end{array}$ & $\begin{array}{ll}\text { ASTM } & \text { D } \\
5988-96 & \\
\end{array}$ & soil & $\begin{array}{lc}0,5 \mathrm{~g} & \text { ionic } \\
\text { liquid/ } & 300 \mathrm{~g} \text { soil }\end{array}$ & 180 & DOC & [39] \\
\hline 42 & $\begin{array}{l}\mathrm{R}= \\
\mathrm{C}_{2} \mathrm{H}_{5} \mathrm{OC}_{2} \mathrm{H}_{5}\end{array}$ & $\mathrm{Br}$ & 0 & $\begin{array}{l}\text { not readily } \\
\text { biodegradable }\end{array}$ & $\begin{array}{l}\text { modified } \\
\text { OECD } \\
\text { 301D Test }\end{array}$ & $\begin{array}{l}\text { activated } \\
\text { sludge }\end{array}$ & $200 \mu \mathrm{mol} / \mathrm{L}$ & 31 & $\begin{array}{l}\text { primary } \\
\text { biodegradation }\end{array}$ & [18] \\
\hline 43 & $\begin{array}{l}\mathrm{R}= \\
\mathrm{C}_{3} \mathrm{H}_{7} \mathrm{OCH}_{3}\end{array}$ & $\mathrm{Br}^{-}$ & 0 & $\begin{array}{l}\text { not readily } \\
\text { biodegradable }\end{array}$ & $\begin{array}{l}\text { modified } \\
\text { OECD } \\
\text { 301D Test }\end{array}$ & $\begin{array}{l}\text { activated } \\
\text { sludge }\end{array}$ & $200 \mu \mathrm{mol} / \mathrm{L}$ & 31 & $\begin{array}{l}\text { primary } \\
\text { biodegradation }\end{array}$ & [18] \\
\hline 44 & $\mathrm{R}=-\mathrm{C}_{4} \mathrm{H}_{8} \mathrm{SO}_{3}{ }^{-}$ & - & $<5$ & $\begin{array}{l}\text { not readily } \\
\text { biodegradable }\end{array}$ & $\begin{array}{l}\text { " } \mathrm{CO}_{2} \\
\text { headspace" } \\
\text { Test (ISO } \\
14593 \text { ) }\end{array}$ & $\begin{array}{l}\text { activated } \\
\text { sludge }\end{array}$ & $40 \mathrm{mg} / \mathrm{L}$ & 28 & TOC & [31] \\
\hline 45 & $\mathrm{R}=-$ benzyl & $\mathrm{Cl}^{-}$ & 0 & $\begin{array}{l}\text { not readily } \\
\text { biodegradable }\end{array}$ & $\begin{array}{l}\text { modified } \\
\text { OECD } \\
\text { 301D Test }\end{array}$ & $\begin{array}{l}\text { activated } \\
\text { sludge }\end{array}$ & $200 \mu \mathrm{mol} / \mathrm{L}$ & 31 & $\begin{array}{l}\text { primary } \\
\text { biodegradation }\end{array}$ & [18] \\
\hline 46 & $\mathrm{R}=$-benzyl & $\mathrm{Br}$ & $<5$ & $\begin{array}{l}\text { not readily } \\
\text { biodegradable }\end{array}$ & $\begin{array}{l}\text { " } \mathrm{CO}_{2} \\
\text { headspace" } \\
\text { Test (ISO } \\
14593)\end{array}$ & $\begin{array}{l}\text { activated } \\
\text { sludge }\end{array}$ & $40 \mathrm{mg} / \mathrm{L}$ & 28 & TOC & [31] \\
\hline 47 & $\mathrm{R}=-$ benzyl & $\begin{array}{l}\mathrm{C}_{8} \mathrm{H}_{17} \mathrm{OS} \\
\mathrm{O}_{3}^{-}\end{array}$ & 38 & $\begin{array}{l}\text { not readily } \\
\text { biodegradable }\end{array}$ & $\begin{array}{l}\text { " } \mathrm{CO}_{2} \\
\text { headspace" } \\
\text { Test (ISO } \\
14593)\end{array}$ & $\begin{array}{l}\text { activated } \\
\text { sludge }\end{array}$ & $40 \mathrm{mg} / \mathrm{L}$ & 28 & TOC & [31] \\
\hline
\end{tabular}




\begin{tabular}{|c|c|c|c|c|c|c|c|c|c|c|c|}
\hline 48 & & $\begin{array}{l}\mathrm{R}= \\
\mathrm{CH}_{2} \mathrm{C}(\mathrm{O}) \text { pyrr } \\
\text { olidine }\end{array}$ & $\begin{array}{l}\mathrm{C}_{8} \mathrm{H}_{17} \mathrm{OS} \\
\mathrm{O}_{3}^{-}\end{array}$ & 36 & $\begin{array}{l}\text { not readily } \\
\text { biodegradable }\end{array}$ & $\begin{array}{l}\text { "'CO } \mathrm{CO}_{2} \\
\text { headspace" } \\
\text { Test (ISO } \\
14593 \text { ) }\end{array}$ & $\begin{array}{l}\text { activated } \\
\text { sludge }\end{array}$ & $40 \mathrm{mg} / \mathrm{L}$ & 28 & TOC & [33] \\
\hline 49 & $\widehat{\sim}_{\underbrace{ \pm} \widehat{\Phi}^{\prime}}{ }^{R}$ & $\begin{array}{l}\mathrm{R}= \\
\mathrm{CH}_{2}=\mathrm{CH}_{2}\end{array}$ & $\mathrm{I}^{-}$ & $<5$ & $\begin{array}{l}\text { not readily } \\
\text { biodegradable }\end{array}$ & $\begin{array}{l}\text { " } \mathrm{CO}_{2} \\
\text { headspace" } \\
\text { Test (ISO } \\
14593 \text { ) }\end{array}$ & $\begin{array}{l}\text { activated } \\
\text { sludge }\end{array}$ & $40 \mathrm{mg} / \mathrm{L}$ & 28 & TOC & [31] \\
\hline 50 & & $\begin{array}{l}\mathrm{R}= \\
\mathrm{CH}_{2}=\mathrm{CH}_{2}\end{array}$ & $\begin{array}{l}\mathrm{C}_{8} \mathrm{H}_{17} \mathrm{OS} \\
\mathrm{O}_{3}^{-}\end{array}$ & 43 & $\begin{array}{l}\text { not readily } \\
\text { biodegradable }\end{array}$ & $\begin{array}{l}\text { "CO} \mathrm{CO}_{2} \\
\text { headspace", } \\
\text { Test (ISO } \\
14593 \text { ) }\end{array}$ & $\begin{array}{l}\text { activated } \\
\text { sludge }\end{array}$ & $40 \mathrm{mg} / \mathrm{L}$ & 28 & TOC & [31] \\
\hline 51 & 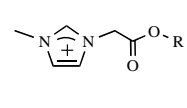 & $\mathrm{R}=-\mathrm{CH}_{3}$ & $\mathrm{Br}$ & $\sim 17$ & $\begin{array}{l}\text { not readily } \\
\text { biodegradable }\end{array}$ & $\begin{array}{l}\text { "Closed } \\
\text { Bottle" Test } \\
\text { (OECD } \\
\text { 301D) }\end{array}$ & $\begin{array}{l}\text { wastewater } \\
\text { organisms }\end{array}$ & $2 \mathrm{mg} / \mathrm{L}$ & 28 & BOD & [27] \\
\hline $52 \mathrm{a}$ & & $\mathrm{R}=-\mathrm{C}_{2} \mathrm{H}_{5}$ & $\mathrm{Br}$ & $\sim 22$ & $\begin{array}{l}\text { not readily } \\
\text { biodegradable }\end{array}$ & $\begin{array}{l}\text { "Closed } \\
\text { Bottle" Test } \\
\text { (OECD } \\
\text { 301D) }\end{array}$ & $\begin{array}{l}\text { wastewater } \\
\text { organisms }\end{array}$ & $2 \mathrm{mg} / \mathrm{L}$ & 28 & BOD & [27] \\
\hline $52 \mathrm{~b}$ & & $\mathrm{R}=-\mathrm{C}_{2} \mathrm{H}_{5}$ & $\mathrm{Br}$ & 48 & $\begin{array}{l}\text { not readily } \\
\text { biodegradable }\end{array}$ & $\begin{array}{l}\text { Modified } \\
\text { "Sturm" } \\
\text { test (OECD } \\
301 \mathrm{~B})\end{array}$ & not specified & not specified & $\begin{array}{l}\text { not speci- } \\
\text { fied }\end{array}$ & not specified & [27] \\
\hline 53 & & $\mathrm{R}=-\mathrm{C}_{2} \mathrm{H}_{5}$ & $\mathrm{BF}_{4}^{-}$ & 59 & $\begin{array}{l}\text { not readily } \\
\text { biodegradable }\end{array}$ & $\begin{array}{l}\text { Modified } \\
\text { "Sturm" } \\
\text { test (OECD } \\
301 \mathrm{~B})\end{array}$ & not specified & not specified & $\begin{array}{l}\text { not speci- } \\
\text { fied }\end{array}$ & not specified & [27] \\
\hline $54 \mathrm{a}$ & & $\mathrm{R}=-\mathrm{C}_{3} \mathrm{H}_{7}$ & $\mathrm{Br}$ & $\sim 19$ & $\begin{array}{l}\text { not readily } \\
\text { biodegradable }\end{array}$ & $\begin{array}{l}\text { "Closed } \\
\text { Bottle" Test } \\
\text { (OECD } \\
\text { 301D) }\end{array}$ & $\begin{array}{l}\text { wastewater } \\
\text { organisms }\end{array}$ & $2 \mathrm{mg} / \mathrm{L}$ & 28 & BOD & [27] \\
\hline $54 \mathrm{~b}$ & & $\mathrm{R}=-\mathrm{C}_{3} \mathrm{H}_{7}$ & $\mathrm{Br}$ & 24 & $\begin{array}{l}\text { not readily } \\
\text { biodegradable }\end{array}$ & $\begin{array}{l}\text { "Closed } \\
\text { Bottle" Test } \\
\text { (OECD } \\
\text { 301D) }\end{array}$ & $\begin{array}{l}\text { wastewater } \\
\text { organisms }\end{array}$ & $2 \mathrm{mg} / \mathrm{L}$ & 28 & BOD & [29] \\
\hline $54 \mathrm{c}$ & & $\mathrm{R}=-\mathrm{C}_{3} \mathrm{H}_{7}$ & $\mathrm{Br}^{-}$ & 24 & $\begin{array}{l}\text { not readily } \\
\text { biodegradable }\end{array}$ & $\begin{array}{l}\text { "'CO}{ }_{2} \\
\text { headspace", } \\
\text { Test (ISO } \\
14593 \text { ) }\end{array}$ & $\begin{array}{l}\text { wastewater } \\
\text { organisms }\end{array}$ & $40 \mathrm{mg} / \mathrm{L}$ & 28 & TOC & [29] \\
\hline 55 & & $\mathrm{R}=-\mathrm{C}_{3} \mathrm{H}_{7}$ & $\mathrm{BF}_{4}^{-}$ & $<20$ & $\begin{array}{l}\text { not readily } \\
\text { biodegradable }\end{array}$ & $\begin{array}{l}\text { "Closed } \\
\text { Bottle" Test } \\
\text { (OECD } \\
\text { 301D) }\end{array}$ & $\begin{array}{l}\text { wastewater } \\
\text { organisms }\end{array}$ & $2 \mathrm{mg} / \mathrm{L}$ & 28 & BOD & [28] \\
\hline 56 & & $\mathrm{R}=-\mathrm{C}_{3} \mathrm{H}_{7}$ & $\mathrm{PF}_{6}^{-}$ & $<20$ & $\begin{array}{l}\text { not readily } \\
\text { biodegradable }\end{array}$ & $\begin{array}{l}\text { "Closed } \\
\text { Bottle" Test } \\
\text { (OECD } \\
\text { 301D) }\end{array}$ & $\begin{array}{l}\text { wastewater } \\
\text { organisms }\end{array}$ & $2 \mathrm{mg} / \mathrm{L}$ & 28 & BOD & [28] \\
\hline 57 & & $\mathrm{R}=-\mathrm{C}_{3} \mathrm{H}_{7}$ & $\begin{array}{l}\left(\mathrm{CF}_{3} \mathrm{SO}_{2}\right) \\
{ }_{2} \mathrm{~N}^{-}\end{array}$ & $\sim 20$ & $\begin{array}{l}\text { not readily } \\
\text { biodegradable }\end{array}$ & $\begin{array}{l}\text { "Closed } \\
\text { Bottle" Test } \\
\text { (OECD } \\
\text { 301D) }\end{array}$ & $\begin{array}{l}\text { wastewater } \\
\text { organisms }\end{array}$ & $2 \mathrm{mg} / \mathrm{L}$ & 28 & BOD & [28] \\
\hline 58 & & $\mathrm{R}=-\mathrm{C}_{3} \mathrm{H}_{7}$ & $\mathrm{~N}(\mathrm{CN})_{2}^{-}$ & $\sim 32$ & $\begin{array}{l}\text { not readily } \\
\text { biodegradable }\end{array}$ & $\begin{array}{l}\text { "Closed } \\
\text { Bottle" Test } \\
\text { (OECD } \\
\text { 301D) }\end{array}$ & $\begin{array}{l}\text { wastewater } \\
\text { organisms }\end{array}$ & $2 \mathrm{mg} / \mathrm{L}$ & 28 & BOD & [28] \\
\hline $59 \mathrm{a}$ & & $\mathrm{R}=-\mathrm{C}_{3} \mathrm{H}_{7}$ & $\begin{array}{l}\mathrm{C}_{8} \mathrm{H}_{17} \mathrm{OS} \\
\mathrm{O}_{3}^{-}\end{array}$ & 49 & $\begin{array}{l}\text { not readily } \\
\text { biodegradable }\end{array}$ & $\begin{array}{l}\text { "Closed } \\
\text { Bottle" Test } \\
\text { (OECD } \\
\text { 301D) }\end{array}$ & $\begin{array}{l}\text { wastewater } \\
\text { organisms }\end{array}$ & $2 \mathrm{mg} / \mathrm{L}$ & 28 & BOD & [28] \\
\hline $59 \mathrm{~b}$ & & $\mathrm{R}=-\mathrm{C}_{3} \mathrm{H}_{7}$ & $\begin{array}{l}\mathrm{C}_{8} \mathrm{H}_{17} \mathrm{OS} \\
\mathrm{O}_{3}^{-}\end{array}$ & 49 & $\begin{array}{l}\text { not readily } \\
\text { biodegradable }\end{array}$ & $\begin{array}{l}\text { "Closed } \\
\text { Bottle" Test } \\
\text { (OECD } \\
\text { 301D) }\end{array}$ & $\begin{array}{l}\text { wastewater } \\
\text { organisms }\end{array}$ & $2 \mathrm{mg} / \mathrm{L}$ & 28 & BOD & [29] \\
\hline $59 \mathrm{c}$ & & $\mathrm{R}=-\mathrm{C}_{3} \mathrm{H}_{7}$ & $\begin{array}{l}\mathrm{C}_{8} \mathrm{H}_{17} \mathrm{OS} \\
\mathrm{O}_{3}^{-}\end{array}$ & 64 & $\begin{array}{l}\text { readily biode- } \\
\text { gradable }\end{array}$ & $\begin{array}{l}\text { "CO } \mathrm{CO}_{2} \\
\text { headspace", } \\
\text { Test (ISO } \\
14593 \text { ) }\end{array}$ & $\begin{array}{l}\text { wastewater } \\
\text { organisms }\end{array}$ & $40 \mathrm{mg} / \mathrm{L}$ & 28 & TOC & [29] \\
\hline 60 & & $\mathrm{R}=-\mathrm{C}_{4} \mathrm{H}_{9}$ & $\mathrm{Br}$ & $\sim 30$ & $\begin{array}{l}\text { not readily } \\
\text { biodegradable }\end{array}$ & $\begin{array}{l}\text { "Closed } \\
\text { Bottle" Test } \\
\text { (OECD } \\
\text { 301D) }\end{array}$ & $\begin{array}{l}\text { wastewater } \\
\text { organisms }\end{array}$ & $2 \mathrm{mg} / \mathrm{L}$ & 28 & BOD & [27] \\
\hline 61 & & $\mathrm{R}=-\mathrm{C}_{4} \mathrm{H}_{9}$ & $\begin{array}{l}\mathrm{C}_{8} \mathrm{H}_{17} \mathrm{OS} \\
\mathrm{O}_{3}^{-}\end{array}$ & 59 & $\begin{array}{l}\text { not readily } \\
\text { biodegradable }\end{array}$ & $\begin{array}{l}\text { "CO } \mathrm{CO}_{2} \\
\text { headspace" } \\
\text { Test (ISO } \\
14593 \text { ) }\end{array}$ & $\begin{array}{l}\text { activated } \\
\text { sludge }\end{array}$ & $40 \mathrm{mg} / \mathrm{L}$ & 28 & TOC & [33] \\
\hline $62 \mathrm{a}$ & & $\mathrm{R}=-\mathrm{C}_{5} \mathrm{H}_{11}$ & $\mathrm{Br}$ & $\sim 32$ & $\begin{array}{l}\text { not readily } \\
\text { biodegradable }\end{array}$ & $\begin{array}{l}\text { "Closed } \\
\text { Bottle" Test } \\
\text { (OECD } \\
\text { 301D) }\end{array}$ & $\begin{array}{l}\text { wastewater } \\
\text { organisms }\end{array}$ & $2 \mathrm{mg} / \mathrm{L}$ & 28 & BOD & [27] \\
\hline $62 b$ & & $\mathrm{R}=-\mathrm{C}_{5} \mathrm{H}_{11}$ & $\mathrm{Br}$ & 32 & $\begin{array}{l}\text { not readily } \\
\text { biodegradable }\end{array}$ & $\begin{array}{l}\text { "Closed } \\
\text { Bottle" Test } \\
\text { (OECD } \\
\text { 301D) }\end{array}$ & $\begin{array}{l}\text { wastewater } \\
\text { organisms }\end{array}$ & $2 \mathrm{mg} / \mathrm{L}$ & 28 & BOD & [29] \\
\hline
\end{tabular}




\begin{tabular}{|c|c|c|c|c|c|c|c|c|c|c|}
\hline $62 \mathrm{c}$ & $\mathrm{R}=-\mathrm{C}_{5} \mathrm{H}_{11}$ & $\mathrm{Br}^{-}$ & 41 & $\begin{array}{l}\text { not readily } \\
\text { biodegradable }\end{array}$ & $\begin{array}{l}\text { "'CO}{ }_{2} \\
\text { headspace" } \\
\text { Test (ISO } \\
14593 \text { ) }\end{array}$ & $\begin{array}{l}\text { wastewater } \\
\text { organisms }\end{array}$ & $40 \mathrm{mg} / \mathrm{L}$ & 28 & TOC & [29] \\
\hline $62 \mathrm{~d}$ & $\mathrm{R}=-\mathrm{C}_{5} \mathrm{H}_{11}$ & $\mathrm{Br}^{-}$ & $\sim 38$ & $\begin{array}{l}\text { not readily } \\
\text { biodegradable }\end{array}$ & $\begin{array}{l}\text { " } \mathrm{CO}_{2} \\
\text { headspace" } \\
\text { Test (ISO } \\
14593 \text { ) }\end{array}$ & $\begin{array}{l}\text { activated } \\
\text { sludge }\end{array}$ & $40 \mathrm{mg} / \mathrm{L}$ & 28 & TOC & [31] \\
\hline $63 a$ & $\mathrm{R}=-\mathrm{C}_{5} \mathrm{H}_{11}$ & $\begin{array}{l}\mathrm{C}_{8} \mathrm{H}_{17} \mathrm{OS} \\
\mathrm{O}_{3}^{-}\end{array}$ & 54 & $\begin{array}{l}\text { not readily } \\
\text { biodegradable }\end{array}$ & $\begin{array}{l}\text { "Closed } \\
\text { Bottle" Test } \\
\text { (OECD } \\
\text { 301D) }\end{array}$ & $\begin{array}{l}\text { wastewater } \\
\text { organisms }\end{array}$ & $2 \mathrm{mg} / \mathrm{L}$ & 28 & BOD & [29] \\
\hline $63 b$ & $\mathrm{R}=-\mathrm{C}_{5} \mathrm{H}_{11}$ & $\begin{array}{l}\mathrm{C}_{8} \mathrm{H}_{17} \mathrm{OS} \\
\mathrm{O}_{3}^{-}\end{array}$ & 67 & $\begin{array}{l}\text { readily biode- } \\
\text { gradable }\end{array}$ & $\begin{array}{l}\text { " } \mathrm{CO}_{2} \\
\text { headspace" } \\
\text { Test (ISO } \\
14593 \text { ) }\end{array}$ & $\begin{array}{l}\text { wastewater } \\
\text { organisms }\end{array}$ & $40 \mathrm{mg} / \mathrm{L}$ & 28 & TOC & [29] \\
\hline $63 \mathrm{c}$ & $\mathrm{R}=-\mathrm{C}_{5} \mathrm{H}_{11}$ & $\begin{array}{l}\mathrm{C}_{8} \mathrm{H}_{17} \mathrm{OS} \\
\mathrm{O}_{3}^{-}\end{array}$ & $\sim 63$ & $\begin{array}{l}\text { readily biode- } \\
\text { gradable }\end{array}$ & $\begin{array}{l}\text { " } \mathrm{CO}_{2} \\
\text { headspace" } \\
\text { Test (ISO } \\
14593 \text { ) }\end{array}$ & $\begin{array}{l}\text { activated } \\
\text { sludge }\end{array}$ & $40 \mathrm{mg} / \mathrm{L}$ & 28 & TOC & [31] \\
\hline $63 \mathrm{~d}$ & $\mathrm{R}=-\mathrm{C}_{5} \mathrm{H}_{11}$ & $\begin{array}{l}\mathrm{C}_{8} \mathrm{H}_{17} \mathrm{OS} \\
\mathrm{O}_{3}^{-}\end{array}$ & 64 & $\begin{array}{l}\text { readily biode- } \\
\text { gradable }\end{array}$ & $\begin{array}{l}\text { " } \mathrm{CO}_{2} \\
\text { headspace" } \\
\text { Test (ISO } \\
14593 \text { ) }\end{array}$ & $\begin{array}{l}\text { activated } \\
\text { sludge }\end{array}$ & $40 \mathrm{mg} / \mathrm{L}$ & 28 & TOC & [33] \\
\hline 64 & $\mathrm{R}=-\mathrm{C}_{5} \mathrm{H}_{11}$ & $\begin{array}{l}\mathrm{C}_{12} \mathrm{H}_{25} \mathrm{OS} \\
\mathrm{O}_{3}^{-}\end{array}$ & 72 & $\begin{array}{l}\text { readily biode- } \\
\text { gradable }\end{array}$ & $\begin{array}{l}\text { "'CO } \\
\text { headspace", } \\
\text { Test (ISO } \\
14593 \text { ) }\end{array}$ & $\begin{array}{l}\text { activated } \\
\text { sludge }\end{array}$ & $40 \mathrm{mg} / \mathrm{L}$ & 28 & TOC & [31] \\
\hline 65 & $\mathrm{R}=-\mathrm{C}_{5} \mathrm{H}_{11}$ & $\mathrm{CH}_{3} \mathrm{SO}_{3}^{-}$ & 35 & $\begin{array}{l}\text { not readily } \\
\text { biodegradable }\end{array}$ & $\begin{array}{l}\text { " } \mathrm{CO}_{2} \\
\text { headspace" } \\
\text { Test (ISO } \\
14593 \text { ) }\end{array}$ & $\begin{array}{l}\text { activated } \\
\text { sludge }\end{array}$ & $40 \mathrm{mg} / \mathrm{L}$ & 28 & TOC & [31] \\
\hline 66 & $\mathrm{R}=-\mathrm{C}_{5} \mathrm{H}_{11}$ & $\begin{array}{l}\text { sacchari- } \\
\text { nate }\end{array}$ & 61 & $\begin{array}{l}\text { readily biode- } \\
\text { gradable }\end{array}$ & $\begin{array}{l}\text { "'CO } \\
\text { headspace" } \\
\text { Test (ISO } \\
14593 \text { ) }\end{array}$ & $\begin{array}{l}\text { activated } \\
\text { sludge }\end{array}$ & $40 \mathrm{mg} / \mathrm{L}$ & 28 & TOC & [31] \\
\hline 67 & $\mathrm{R}=-\mathrm{C}_{6} \mathrm{H}_{13}$ & $\mathrm{Br}^{-}$ & $\sim 26$ & $\begin{array}{l}\text { not readily } \\
\text { biodegradable }\end{array}$ & $\begin{array}{l}\text { "Closed } \\
\text { Bottle" Test } \\
\text { (OECD } \\
\text { 301D) }\end{array}$ & $\begin{array}{l}\text { wastewater } \\
\text { organisms }\end{array}$ & $2 \mathrm{mg} / \mathrm{L}$ & 28 & BOD & [27] \\
\hline 68 & $\mathrm{R}=-\mathrm{C}_{8} \mathrm{H}_{17}$ & $\mathrm{Br}$ & $\sim 33$ & $\begin{array}{l}\text { not readily } \\
\text { biodegradable }\end{array}$ & $\begin{array}{l}\text { "Closed } \\
\text { Bottle" Test } \\
\text { (OECD } \\
\text { 301D) }\end{array}$ & $\begin{array}{l}\text { wastewater } \\
\text { organisms }\end{array}$ & $2 \mathrm{mg} / \mathrm{L}$ & 28 & BOD & [27] \\
\hline 69 & $\begin{array}{l}\mathrm{R}= \\
\mathrm{C}_{2} \mathrm{H}_{4} \mathrm{OCH}_{3}\end{array}$ & $\begin{array}{l}\mathrm{C}_{8} \mathrm{H}_{17} \mathrm{OS} \\
\mathrm{O}_{3}^{-}\end{array}$ & 59 & $\begin{array}{l}\text { not readily } \\
\text { biodegradable }\end{array}$ & $\begin{array}{l}\text { " } \mathrm{CO}_{2} \\
\text { headspace" } \\
\text { Test (ISO } \\
14593 \text { ) }\end{array}$ & $\begin{array}{l}\text { activated } \\
\text { sludge }\end{array}$ & $40 \mathrm{mg} / \mathrm{L}$ & 28 & TOC & [33] \\
\hline 70 & $\begin{array}{l}\mathrm{R}= \\
\mathrm{C}_{2} \mathrm{H}_{4} \mathrm{OC}_{2} \mathrm{H}_{5}\end{array}$ & $\begin{array}{l}\mathrm{C}_{8} \mathrm{H}_{17} \mathrm{OS} \\
\mathrm{O}_{3}^{-}\end{array}$ & 57 & $\begin{array}{l}\text { not readily } \\
\text { biodegradable }\end{array}$ & $\begin{array}{l}\text { " } \mathrm{CO}_{2} \\
\text { headspace", } \\
\text { Test (ISO } \\
14593 \text { ) }\end{array}$ & $\begin{array}{l}\text { activated } \\
\text { sludge }\end{array}$ & $40 \mathrm{mg} / \mathrm{L}$ & 28 & TOC & [33] \\
\hline 71 & $\begin{array}{l}\mathrm{R}= \\
\mathrm{C}_{2} \mathrm{H}_{4} \mathrm{OC}_{3} \mathrm{H}_{7}\end{array}$ & $\begin{array}{l}\mathrm{C}_{8} \mathrm{H}_{17} \mathrm{OS} \\
\mathrm{O}_{3}^{-}\end{array}$ & 65 & $\begin{array}{l}\text { readily biode- } \\
\text { gradable }\end{array}$ & $\begin{array}{l}\text { " } \mathrm{CO}_{2} \\
\text { headspace" } \\
\text { Test (ISO } \\
14593 \text { ) }\end{array}$ & $\begin{array}{l}\text { activated } \\
\text { sludge }\end{array}$ & $40 \mathrm{mg} / \mathrm{L}$ & 28 & TOC & [33] \\
\hline 72 & $\begin{array}{l}\mathrm{R}= \\
\mathrm{C}_{2} \mathrm{H}_{4} \mathrm{OC}_{4} \mathrm{H}_{9}\end{array}$ & $\begin{array}{l}\mathrm{C}_{8} \mathrm{H}_{17} \mathrm{OS} \\
\mathrm{O}_{3}^{-}\end{array}$ & 61 & $\begin{array}{l}\text { readily biode- } \\
\text { gradable }\end{array}$ & $\begin{array}{l}\text { "'CO} \mathrm{CO}_{2} \\
\text { headspace" } \\
\text { Test (ISO } \\
14593 \text { ) }\end{array}$ & $\begin{array}{l}\text { activated } \\
\text { sludge }\end{array}$ & $40 \mathrm{mg} / \mathrm{L}$ & 28 & TOC & [33] \\
\hline 73 & $\begin{array}{l}\mathrm{R}= \\
\mathrm{C}_{2} \mathrm{H}_{4} \mathrm{OC}_{2} \mathrm{H}_{4} \mathrm{O} \\
\mathrm{CH}_{3}\end{array}$ & $\begin{array}{l}\mathrm{C}_{8} \mathrm{H}_{17} \mathrm{OS} \\
\mathrm{O}_{3}^{-}\end{array}$ & 58 & $\begin{array}{l}\text { not readily } \\
\text { biodegradable }\end{array}$ & $\begin{array}{l}\text { " } \mathrm{CO}_{2} \\
\text { headspace" } \\
\text { Test (ISO } \\
14593 \text { ) }\end{array}$ & $\begin{array}{l}\text { activated } \\
\text { sludge }\end{array}$ & $40 \mathrm{mg} / \mathrm{L}$ & 28 & TOC & [33] \\
\hline 74 & $\begin{array}{l}\mathrm{R}= \\
\mathrm{C}_{2} \mathrm{H}_{4} \mathrm{OC}_{2} \mathrm{H}_{4} \mathrm{O} \\
\mathrm{C}_{2} \mathrm{H}_{5}\end{array}$ & $\begin{array}{l}\mathrm{C}_{8} \mathrm{H}_{17} \mathrm{OS} \\
\mathrm{O}_{3}^{-}\end{array}$ & 56 & $\begin{array}{l}\text { not readily } \\
\text { biodegradable }\end{array}$ & $\begin{array}{l}\text { " } \mathrm{CO}_{2} \\
\text { headspace" } \\
\text { Test (ISO } \\
14593 \text { ) }\end{array}$ & $\begin{array}{l}\text { activated } \\
\text { sludge }\end{array}$ & $40 \mathrm{mg} / \mathrm{L}$ & 28 & TOC & [33] \\
\hline 75 & $\begin{array}{l}\mathrm{R}= \\
\mathrm{C}_{2} \mathrm{H}_{4} \mathrm{OC}_{2} \mathrm{H}_{4} \mathrm{O} \\
\mathrm{C}_{3} \mathrm{H}_{7}\end{array}$ & $\begin{array}{l}\mathrm{C}_{8} \mathrm{H}_{17} \mathrm{OS} \\
\mathrm{O}_{3}^{-}\end{array}$ & 66 & $\begin{array}{l}\text { readily biode- } \\
\text { gradable }\end{array}$ & $\begin{array}{l}\text { " } \mathrm{CO}_{2} \\
\text { headspace", } \\
\text { Test (ISO } \\
14593 \text { ) }\end{array}$ & $\begin{array}{l}\text { activated } \\
\text { sludge }\end{array}$ & $40 \mathrm{mg} / \mathrm{L}$ & 28 & TOC & [33] \\
\hline 76 & $\begin{array}{l}\mathrm{R}= \\
\mathrm{C}_{2} \mathrm{H}_{4} \mathrm{OC}_{2} \mathrm{H}_{4} \mathrm{O} \\
\mathrm{C}_{4} \mathrm{H}_{9}\end{array}$ & $\begin{array}{l}\mathrm{C}_{8} \mathrm{H}_{17} \mathrm{OS} \\
\mathrm{O}_{3}^{-}\end{array}$ & 65 & $\begin{array}{l}\text { readily biode- } \\
\text { gradable }\end{array}$ & $\begin{array}{l}\text { " } \mathrm{CO}_{2} \\
\text { headspace" } \\
\text { Test (ISO } \\
14593 \text { ) }\end{array}$ & $\begin{array}{l}\text { activated } \\
\text { sludge }\end{array}$ & $40 \mathrm{mg} / \mathrm{L}$ & 28 & TOC & [33] \\
\hline 77 & $\begin{array}{l}\mathrm{R}_{1}=-\mathrm{CH}_{3} \\
\mathrm{R}_{2}=-\mathrm{C}_{3} \mathrm{H}_{7}\end{array}$ & $\mathrm{Br}^{-}$ & 23 & $\begin{array}{l}\text { not readily } \\
\text { biodegradable }\end{array}$ & $\begin{array}{l}\text { "Closed } \\
\text { Bottle" Test } \\
\text { (OECD } \\
\text { 301D) }\end{array}$ & $\begin{array}{l}\text { wastewater } \\
\text { organisms }\end{array}$ & $2 \mathrm{mg} / \mathrm{L}$ & 28 & BOD & [29] \\
\hline $78 \mathrm{a}$ & $\begin{array}{l}\mathrm{R}_{1}=-\mathrm{CH}_{3} \\
\mathrm{R}_{2}=-\mathrm{C}_{3} \mathrm{H}_{7}\end{array}$ & $\begin{array}{l}\mathrm{C}_{8} \mathrm{H}_{17} \mathrm{OS} \\
\mathrm{O}_{3}^{-}\end{array}$ & 55 & $\begin{array}{l}\text { not readily } \\
\text { biodegradable }\end{array}$ & $\begin{array}{l}\text { "Closed } \\
\text { Bottle" Test } \\
\text { (OECD } \\
\text { 301D) }\end{array}$ & $\begin{array}{l}\text { wastewater } \\
\text { organisms }\end{array}$ & $2 \mathrm{mg} / \mathrm{L}$ & 28 & BOD & [29] \\
\hline
\end{tabular}




\begin{tabular}{|c|c|c|c|c|c|c|c|c|c|c|c|}
\hline $78 \mathrm{~b}$ & & $\begin{array}{l}\mathrm{R}_{1}=-\mathrm{CH}_{3} \\
\mathrm{R}_{2}=-\mathrm{C}_{3} \mathrm{H}_{7}\end{array}$ & $\begin{array}{l}\mathrm{C}_{8} \mathrm{H}_{17} \mathrm{OS} \\
\mathrm{O}_{3}^{-}\end{array}$ & 62 & $\begin{array}{l}\text { readily biode- } \\
\text { gradable }\end{array}$ & $\begin{array}{l}\text { "'CO } \mathrm{CO}_{2} \\
\text { Head- } \\
\text { space" Test } \\
\text { (ISO } \\
14593)\end{array}$ & $\begin{array}{l}\text { wastewater } \\
\text { organisms }\end{array}$ & $40 \mathrm{mg} / \mathrm{L}$ & 28 & TOC & [29] \\
\hline 79 & & $\begin{array}{l}\mathrm{R}_{1}=-\mathrm{CH}_{3} \\
\mathrm{R}_{2}=-\mathrm{C}_{5} \mathrm{H}_{11}\end{array}$ & $\mathrm{Br}$ & 33 & $\begin{array}{l}\text { not readily } \\
\text { biodegradable }\end{array}$ & $\begin{array}{l}\text { "Closed } \\
\text { Bottle" Test } \\
\text { (OECD } \\
\text { 301D) }\end{array}$ & $\begin{array}{l}\text { wastewater } \\
\text { organisms }\end{array}$ & $2 \mathrm{mg} / \mathrm{L}$ & 28 & BOD & [29] \\
\hline $80 \mathrm{a}$ & & $\begin{array}{l}\mathrm{R}_{1}=-\mathrm{CH}_{3} \\
\mathrm{R}_{2}=-\mathrm{C}_{5} \mathrm{H}_{11}\end{array}$ & $\begin{array}{l}\mathrm{C}_{8} \mathrm{H}_{17} \mathrm{OS} \\
\mathrm{O}_{3}\end{array}$ & 56 & $\begin{array}{l}\text { not readily } \\
\text { biodegradable }\end{array}$ & $\begin{array}{l}\text { "Closed } \\
\text { Bottle" Test } \\
\text { (OECD } \\
\text { 301D) }\end{array}$ & $\begin{array}{l}\text { wastewater } \\
\text { organisms }\end{array}$ & $2 \mathrm{mg} / \mathrm{L}$ & 28 & BOD & [29] \\
\hline $80 \mathrm{~b}$ & & $\begin{array}{l}\mathrm{R}_{1}=-\mathrm{CH}_{3} \\
\mathrm{R}_{2}=-\mathrm{C}_{5} \mathrm{H}_{11}\end{array}$ & $\begin{array}{l}\mathrm{C}_{8} \mathrm{H}_{17} \mathrm{OS} \\
\mathrm{O}_{3}^{-}\end{array}$ & 61 & $\begin{array}{l}\text { readily biode- } \\
\text { gradable }\end{array}$ & $\begin{array}{l}\text { " } \mathrm{CO}_{2} \\
\text { headspace" } \\
\text { Test (ISO } \\
\text { 14593) }\end{array}$ & $\begin{array}{l}\text { wastewater } \\
\text { organisms }\end{array}$ & $40 \mathrm{mg} / \mathrm{L}$ & 28 & TOC & [29] \\
\hline 81 & & $\begin{array}{l}\mathrm{R}_{1}=-\mathrm{CH}_{3} \\
\mathrm{R}_{2}= \\
\mathrm{C}_{2} \mathrm{H}_{4} \mathrm{OC}_{4} \mathrm{H}_{9}\end{array}$ & $\begin{array}{l}\mathrm{C}_{8} \mathrm{H}_{17} \mathrm{OS} \\
\mathrm{O}_{3}^{-}\end{array}$ & 65 & $\begin{array}{l}\text { readily biode- } \\
\text { gradable }\end{array}$ & $\begin{array}{l}\text { " } \mathrm{CO}_{2} \\
\text { headspace" } \\
\text { Test (ISO } \\
14593)\end{array}$ & $\begin{array}{l}\text { activated } \\
\text { sludge }\end{array}$ & $40 \mathrm{mg} / \mathrm{L}$ & 28 & TOC & [33] \\
\hline 82 & & $\begin{array}{l}\mathrm{R}_{1}=-\mathrm{CH}_{3} \\
\mathrm{R}_{2}= \\
\mathrm{C}_{2} \mathrm{H}_{4} \mathrm{OC}_{2} \mathrm{H}_{4} \mathrm{O} \\
\mathrm{CH}_{3}\end{array}$ & $\begin{array}{l}\mathrm{C}_{8} \mathrm{H}_{17} \mathrm{OS} \\
\mathrm{O}_{3}^{-}\end{array}$ & 55 & $\begin{array}{l}\text { not readily } \\
\text { biodegradable }\end{array}$ & $\begin{array}{l}\text { " } \mathrm{CO}_{2} \\
\text { headspace", } \\
\text { Test (ISO } \\
14593)\end{array}$ & $\begin{array}{l}\text { activated } \\
\text { sludge }\end{array}$ & $40 \mathrm{mg} / \mathrm{L}$ & 28 & TOC & [33] \\
\hline 83 & & $\begin{array}{l}\mathrm{R}_{1}=-\mathrm{CH}_{3} \\
\mathrm{R}_{2}= \\
\mathrm{CH}_{2} \mathrm{C}(\mathrm{O}) \text { pyrr } \\
\text { olidine }\end{array}$ & $\begin{array}{l}\mathrm{C}_{8} \mathrm{H}_{17} \mathrm{OS} \\
\mathrm{O}_{3}^{-}\end{array}$ & 35 & $\begin{array}{l}\text { not readily } \\
\text { biodegradable }\end{array}$ & $\begin{array}{l}\text { " } \mathrm{CO}_{2} \\
\text { headspace" } \\
\text { Test (ISO } \\
14593)\end{array}$ & $\begin{array}{l}\text { activated } \\
\text { sludge }\end{array}$ & $40 \mathrm{mg} / \mathrm{L}$ & 28 & TOC & [33] \\
\hline 84 & 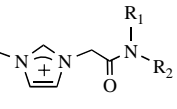 & $\begin{array}{l}\mathrm{R}_{1}=-\mathrm{C}_{2} \mathrm{H}_{5} \\
\mathrm{R}_{2}=-\mathrm{C}_{2} \mathrm{H}_{5}\end{array}$ & $\mathrm{Br}$ & $<10$ & $\begin{array}{l}\text { not readily } \\
\text { biodegradable }\end{array}$ & $\begin{array}{l}\text { "Closed } \\
\text { Bottle" Test } \\
\text { (OECD } \\
\text { 301D) }\end{array}$ & $\begin{array}{l}\text { wastewater } \\
\text { organisms }\end{array}$ & $2 \mathrm{mg} / \mathrm{L}$ & 28 & BOD & [27] \\
\hline 85 & & $\begin{array}{l}\mathrm{R}_{1}=-\mathrm{H} \\
\mathrm{R}_{2}=-\mathrm{C}_{4} \mathrm{H}_{9}\end{array}$ & $\mathrm{Br}^{-}$ & $<10$ & $\begin{array}{l}\text { not readily } \\
\text { biodegradable }\end{array}$ & $\begin{array}{l}\text { "Closed } \\
\text { Bottle" Test } \\
\text { (OECD } \\
\text { 301D) }\end{array}$ & $\begin{array}{l}\text { wastewater } \\
\text { organisms }\end{array}$ & $2 \mathrm{mg} / \mathrm{L}$ & 28 & BOD & [27] \\
\hline 86 & & $\begin{array}{l}\mathrm{R}_{1}=-\mathrm{CH}_{3} \\
\mathrm{R}_{2}=-\mathrm{C}_{4} \mathrm{H}_{9}\end{array}$ & $\mathrm{Br}$ & $<10$ & $\begin{array}{l}\text { not readily } \\
\text { biodegradable }\end{array}$ & $\begin{array}{l}\text { "Closed } \\
\text { Bottle" Test } \\
\text { (OECD } \\
\text { 301D) }\end{array}$ & $\begin{array}{l}\text { wastewater } \\
\text { organisms }\end{array}$ & $2 \mathrm{mg} / \mathrm{L}$ & 28 & BOD & [27] \\
\hline 87 & & $\begin{array}{ll}\mathrm{R}_{1}= & - \\
\mathrm{C}_{2} \mathrm{H}_{4} \mathrm{OCH}_{3} \\
\mathrm{R}_{2}= \\
\mathrm{C}_{2} \mathrm{H}_{4} \mathrm{OCH}_{3}\end{array}$ & $\begin{array}{l}\mathrm{C}_{8} \mathrm{H}_{17} \mathrm{OS} \\
\mathrm{O}_{3}^{-}\end{array}$ & 29 & $\begin{array}{l}\text { not readily } \\
\text { biodegradable }\end{array}$ & $\begin{array}{l}\text { " } \mathrm{CO}_{2} \\
\text { headspace", } \\
\text { Test (ISO } \\
14593)\end{array}$ & $\begin{array}{l}\text { activated } \\
\text { sludge }\end{array}$ & $40 \mathrm{mg} / \mathrm{L}$ & 28 & TOC & [33] \\
\hline
\end{tabular}

Primary biodegradation: Breakdown of test chemical is measured by high-performance liquid chromatography (HPLC).

BOD: Biochemical oxygen demand is the amount of oxygen consumed by microorganisms when metabolizing the test chemical. The BOD is expressed in mg oxygen depletion per mg test chemical.

TOC: Total organic carbon is the amount of carbon bound in an organic test chemical.

COD: Chemical oxygen demand is the amount of oxygen consumed during the oxidation of a test chemical with hot, acid dichromate. The COD is used to measure indirectly the amount of oxidizable organic matter in solution.

DOC: Dissolved organic carbon is a general description of the organic carbon dissolved in water.

Appendix B: Biodegradation Data for Pyridinium Based Ionic Liquids

\begin{tabular}{|c|c|c|c|c|c|c|c|c|c|c|c|}
\hline \multirow[t]{2}{*}{ Nr. } & \multicolumn{3}{|c|}{ Structure } & \multicolumn{2}{|c|}{ Results } & \multicolumn{5}{|c|}{ Test Performance } & \multirow{2}{*}{$\begin{array}{c}\text { Sour } \\
\text { ce }\end{array}$} \\
\hline & Head Group & Side Chain & Anion & $\begin{array}{l}\text { Biodegra- } \\
\text { dation } \\
{[\%]}\end{array}$ & $\begin{array}{l}\text { Classifica- } \\
\text { tion }\end{array}$ & Guideline & Inoculum & $\begin{array}{l}\text { Substance } \\
\text { concentra- } \\
\text { tion }\end{array}$ & $\begin{array}{l}\text { dura- } \\
\text { tion } \\
{[d]}\end{array}$ & $\begin{array}{l}\text { Measured } \\
\text { Parameter }^{*}\end{array}$ & \\
\hline 88 & $\mathrm{~N}^{+}-\mathrm{R}$ & $\mathrm{R}=-\mathrm{C}_{2} \mathrm{H}_{5}$ & $\mathrm{Cl}^{-}$ & 0 & $\begin{array}{l}\text { not readily } \\
\text { biodegrad- } \\
\text { able }\end{array}$ & $\begin{array}{l}\text { Modified } \\
\text { OECD 301D } \\
\text { Test }\end{array}$ & $\begin{array}{l}\text { activated } \\
\text { sludge }\end{array}$ & $200 \mu \mathrm{mol} / \mathrm{L}$ & 31 & $\begin{array}{l}\text { primary } \\
\text { biodegrada- } \\
\text { tion }\end{array}$ & [18] \\
\hline $89 a$ & & $\mathrm{R}=-\mathrm{C}_{4} \mathrm{H}_{9}$ & $\mathrm{Cl}^{-}$ & 0 & $\begin{array}{l}\text { not readily } \\
\text { biodegrad- } \\
\text { able }\end{array}$ & $\begin{array}{l}\text { Modified } \\
\text { OECD 301D } \\
\text { Test }\end{array}$ & $\begin{array}{l}\text { activated } \\
\text { sludge }\end{array}$ & $200 \mu \mathrm{mol} / \mathrm{L}$ & 31 & $\begin{array}{l}\text { primary } \\
\text { biodegrada- } \\
\text { tion }\end{array}$ & [18] \\
\hline $89 \mathrm{~b}$ & & $\mathrm{R}=-\mathrm{C}_{4} \mathrm{H}_{9}$ & $\mathrm{Cl}^{-}$ & 0 & $\begin{array}{l}\text { not readily } \\
\text { biodegrad- } \\
\text { able }\end{array}$ & OECD 301F & $\begin{array}{l}\text { not } \\
\text { specified }\end{array}$ & $100 \mathrm{mg} / \mathrm{L}$ & 28 & $\begin{array}{l}\text { BOD } \\
\text { COD }\end{array}$ & [17] \\
\hline 90 & & $\mathrm{R}=-\mathrm{C}_{8} \mathrm{H}_{17}$ & $\mathrm{Cl}^{-}$ & 100 & $\begin{array}{l}\text { inherently } \\
\text { biodegrad- } \\
\text { able }\end{array}$ & $\begin{array}{l}\text { Modified } \\
\text { OECD 301D } \\
\text { Test }\end{array}$ & $\begin{array}{l}\text { activated } \\
\text { sludge }\end{array}$ & $200 \mu \mathrm{mol} / \mathrm{L}$ & 31 & $\begin{array}{l}\text { primary } \\
\text { biodegrada- } \\
\text { tion }\end{array}$ & [18] \\
\hline 91 & & $\begin{array}{l}\mathrm{R}= \\
\mathrm{CH}_{2} \mathrm{C}(\mathrm{O}) \mathrm{OC}_{2} \mathrm{H}_{5}\end{array}$ & $\mathrm{Br}^{-}$ & 87 & $\begin{array}{l}\text { readily } \\
\text { biodegrad- } \\
\text { able }\end{array}$ & $\begin{array}{l}{ }^{"} \mathrm{CO}_{2} \text {, head- } \\
\text { space" } \\
\text { (ISO 14593) }\end{array}$ & $\begin{array}{l}\text { wastewa- } \\
\text { ter } \\
\text { organisms }\end{array}$ & $40 \mathrm{mg} / \mathrm{L}$ & 28 & TOC & [30] \\
\hline 92 & & $\begin{array}{l}\mathrm{R}= \\
\mathrm{CH}_{2} \mathrm{C}(\mathrm{O}) \mathrm{OC}_{2} \mathrm{H}_{5}\end{array}$ & $\mathrm{C}_{8} \mathrm{H}_{17} \mathrm{OSO}_{3}^{-}$ & 89 & $\begin{array}{l}\text { readily } \\
\text { biodegrad- } \\
\text { able }\end{array}$ & $\begin{array}{l}\text { "CO } \mathrm{CO}_{2} \text { head- } \\
\text { space" Test } \\
\text { (ISO 14593) }\end{array}$ & $\begin{array}{l}\text { wastewa- } \\
\text { ter } \\
\text { organisms }\end{array}$ & $40 \mathrm{mg} / \mathrm{L}$ & 28 & TOC & [30] \\
\hline
\end{tabular}




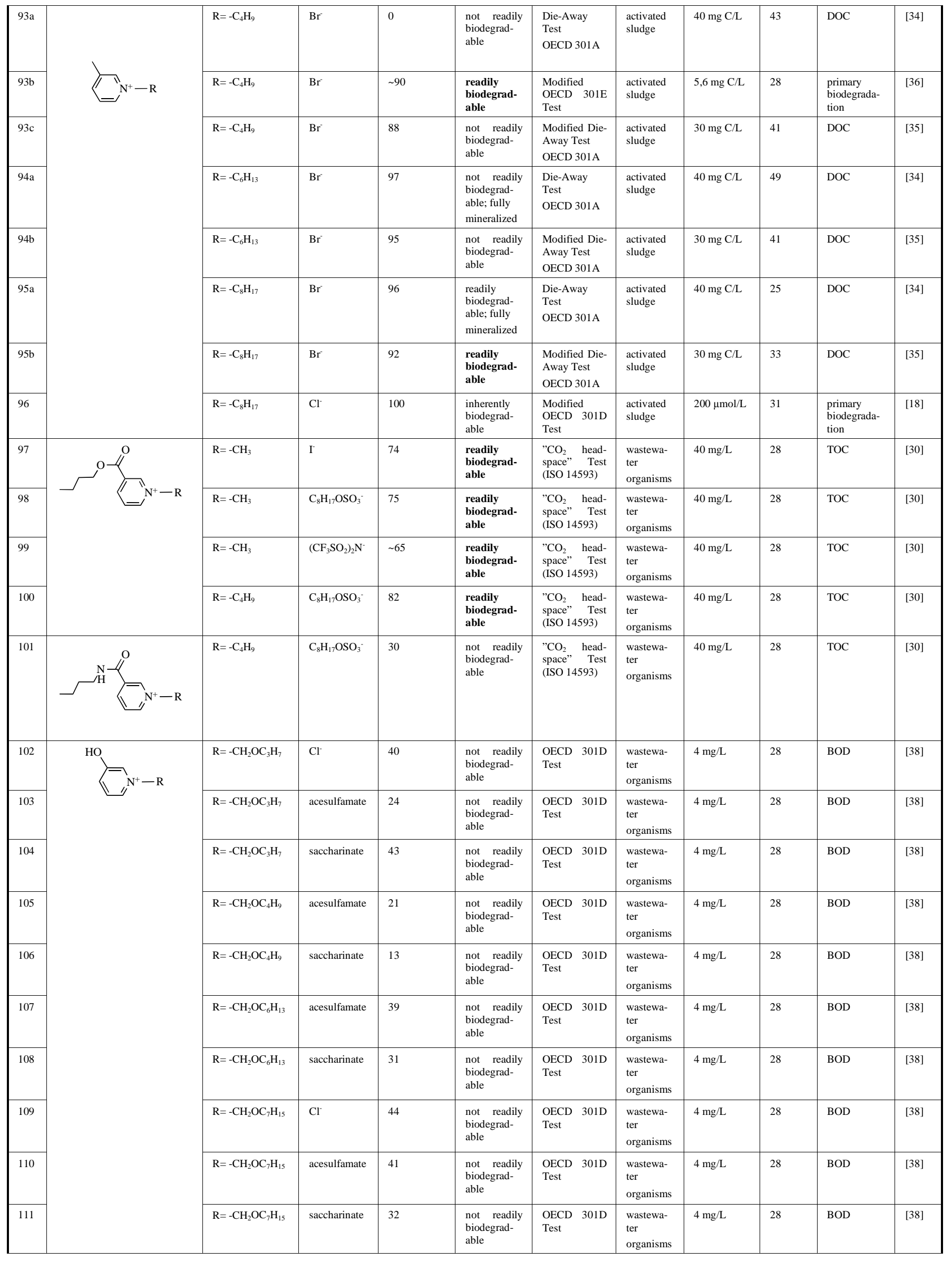




\begin{tabular}{|c|c|c|c|c|c|c|c|c|c|c|c|}
\hline 112 & & $\mathrm{R}=-\mathrm{CH}_{2} \mathrm{OC}_{11} \mathrm{H}_{23}$ & $\mathrm{Cl}^{-}$ & 48 & $\begin{array}{l}\text { not readily } \\
\text { biodegrad- } \\
\text { able }\end{array}$ & $\begin{array}{l}\text { OECD 301D } \\
\text { Test }\end{array}$ & $\begin{array}{l}\text { wastewa- } \\
\text { ter } \\
\text { organisms }\end{array}$ & $4 \mathrm{mg} / \mathrm{L}$ & 28 & BOD & [38] \\
\hline 113 & & $\mathrm{R}=-\mathrm{CH}_{2} \mathrm{OC}_{11} \mathrm{H}_{23}$ & acesulfamate & 49 & $\begin{array}{l}\text { not readily } \\
\text { biodegrad- } \\
\text { able }\end{array}$ & $\begin{array}{l}\text { OECD 301D } \\
\text { Test }\end{array}$ & $\begin{array}{l}\text { wastewa- } \\
\text { ter } \\
\text { organisms }\end{array}$ & $4 \mathrm{mg} / \mathrm{L}$ & 28 & BOD & [38] \\
\hline 114 & & $\mathrm{R}=-\mathrm{CH}_{2} \mathrm{OC}_{11} \mathrm{H}_{23}$ & saccharinate & 72 & $\begin{array}{l}\text { readily } \\
\text { biodegrad- } \\
\text { able }\end{array}$ & $\begin{array}{l}\text { OECD 301D } \\
\text { Test }\end{array}$ & $\begin{array}{l}\text { wastewa- } \\
\text { ter } \\
\text { organisms }\end{array}$ & $4 \mathrm{mg} / \mathrm{L}$ & 28 & BOD & [38] \\
\hline 115 & & $\mathrm{R}=-\mathrm{CH}_{2} \mathrm{OC}_{18} \mathrm{H}_{37}$ & $\mathrm{Cl}^{-}$ & 25 & $\begin{array}{l}\text { not readily } \\
\text { biodegrad- } \\
\text { able }\end{array}$ & $\begin{array}{l}\text { OECD 301D } \\
\text { Test }\end{array}$ & $\begin{array}{l}\text { wastewa- } \\
\text { ter } \\
\text { organisms }\end{array}$ & $4 \mathrm{mg} / \mathrm{L}$ & 28 & BOD & [38] \\
\hline 116 & & $\mathrm{R}=-\mathrm{CH}_{2} \mathrm{OC}_{18} \mathrm{H}_{37}$ & acesulfamate & 32 & $\begin{array}{l}\text { not readily } \\
\text { biodegrad- } \\
\text { able }\end{array}$ & $\begin{array}{l}\text { OECD 301D } \\
\text { Test }\end{array}$ & $\begin{array}{l}\text { wastewa- } \\
\text { ter } \\
\text { organisms }\end{array}$ & $4 \mathrm{mg} / \mathrm{L}$ & 28 & BOD & [38] \\
\hline 117 & & $\mathrm{R}=-\mathrm{CH}_{2} \mathrm{OC}_{18} \mathrm{H}_{37}$ & saccharinate & 20 & $\begin{array}{l}\text { not readily } \\
\text { biodegrad- } \\
\text { able }\end{array}$ & $\begin{array}{l}\text { OECD 301D } \\
\text { Test }\end{array}$ & $\begin{array}{l}\text { wastewa- } \\
\text { ter } \\
\text { organisms }\end{array}$ & $4 \mathrm{mg} / \mathrm{L}$ & 28 & BOD & [38] \\
\hline 118 & ${ }_{N}{ }^{-} \mathrm{N}^{+}-\mathrm{R}$ & $\mathrm{R}=-\mathrm{C}_{2} \mathrm{H}_{5}$ & $\mathrm{Br}$ & 0 & $\begin{array}{l}\text { not readily } \\
\text { biodegrad- } \\
\text { able }\end{array}$ & $\begin{array}{l}\text { Modified } \\
\text { OECD 301D } \\
\text { Test }\end{array}$ & $\begin{array}{l}\text { activated } \\
\text { sludge }\end{array}$ & $200 \mu \mathrm{mol} / \mathrm{L}$ & 31 & $\begin{array}{l}\text { primary } \\
\text { biodegrada- } \\
\text { tion }\end{array}$ & [18] \\
\hline 119 & & $\mathrm{R}=-\mathrm{C}_{4} \mathrm{H}_{9}$ & $\mathrm{Cl}^{-}$ & 0 & $\begin{array}{l}\text { not readily } \\
\text { biodegrad- } \\
\text { able }\end{array}$ & $\begin{array}{l}\text { Modified } \\
\text { OECD 301D } \\
\text { Test }\end{array}$ & $\begin{array}{l}\text { activated } \\
\text { sludge }\end{array}$ & $200 \mu \mathrm{mol} / \mathrm{L}$ & 31 & $\begin{array}{l}\text { primary } \\
\text { biodegrada- } \\
\text { tion }\end{array}$ & [18] \\
\hline 120 & & $\mathrm{R}=-\mathrm{C}_{6} \mathrm{H}_{13}$ & $\mathrm{Cl}^{-}$ & 100 & $\begin{array}{l}\text { inherently } \\
\text { biodegrad- } \\
\text { able }\end{array}$ & $\begin{array}{l}\text { Modified } \\
\text { OECD 301D } \\
\text { Test }\end{array}$ & $\begin{array}{l}\text { activated } \\
\text { sludge }\end{array}$ & $200 \mu \mathrm{mol} / \mathrm{L}$ & 31 & $\begin{array}{l}\text { primary } \\
\text { biodegrada- } \\
\text { tion }\end{array}$ & [18] \\
\hline
\end{tabular}

Primary biodegradation: Breakdown of test chemical is measured by high-performance liquid chromatography (HPLC).

BOD: Biochemical oxygen demand is the amount of oxygen consumed by microorganisms when metabolizing the test chemical. The BOD is expressed in mg oxygen depletion per mg test chemical.

TOC: Total organic carbon is the amount of carbon bound in an organic test chemical.

COD: Chemical oxygen demand is the amount of oxygen consumed during the oxidation of a test chemical with hot, acid dichromate. The COD is used to measure indirectly the amount of oxidizable organic DOC: Dissolved.

DOC: Dissolved organic carbon is a general description of the organic carbon dissolved in water.

\section{Appendix C: Biodegradation Data for Ammonium and Phosphonium Based Ionic Liquids}

\begin{tabular}{|c|c|c|c|c|c|c|c|c|c|c|c|}
\hline \multirow[t]{2}{*}{ Nr. } & \multicolumn{3}{|c|}{ Structure } & \multicolumn{2}{|c|}{ Results } & \multicolumn{5}{|c|}{ Test performance } & \multirow[t]{2}{*}{ Source } \\
\hline & Head Group & Side Chain & Anion & $\begin{array}{l}\text { Biodegrada- } \\
\text { tion } \\
{[\%]}\end{array}$ & Classification & Guideline & Inoculum & $\begin{array}{l}\text { Substance } \\
\text { concentra- } \\
\text { tion }\end{array}$ & $\begin{array}{l}\text { Dura- } \\
\text { tion } \\
\text { [d] }\end{array}$ & $\begin{array}{l}\text { Measured } \\
\text { Parameter }\end{array}$ & \\
\hline 121 & \multirow{12}{*}{ 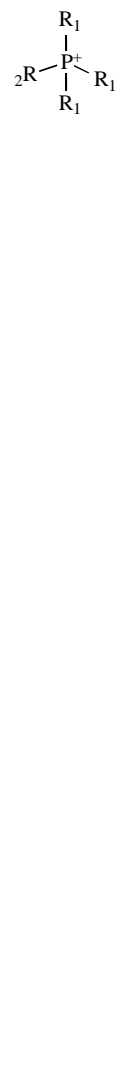 } & $\begin{array}{l}\mathrm{R}_{1}=-\mathrm{C}_{4} \mathrm{H}_{9} \\
\mathrm{R}_{2}=-\mathrm{C}_{2} \mathrm{H}_{5}\end{array}$ & $\left(\mathrm{C}_{2} \mathrm{H}_{5} \mathrm{O}\right)_{2} \mathrm{P}^{-}$ & 9 & $\begin{array}{l}\text { not readily } \\
\text { biodegradable }\end{array}$ & OECD $301 \mathrm{~F}$ & $\begin{array}{l}\text { not speci- } \\
\text { fied }\end{array}$ & $100 \mathrm{mg} / \mathrm{mL}$ & 28 & $\begin{array}{l}\text { BOD } \\
\text { COD }\end{array}$ & [17] \\
\hline 122 & & $\begin{array}{l}\mathrm{R}_{1}=-\mathrm{C}_{6} \mathrm{H}_{13} \\
\mathrm{R}_{2}=- \\
\mathrm{CH}_{2} \mathrm{C}(\mathrm{O}) \mathrm{OC}_{3} \mathrm{H}_{7}\end{array}$ & $\mathrm{Br}^{-}$ & 12 & $\begin{array}{l}\text { not readily } \\
\text { biodegradable }\end{array}$ & $\begin{array}{l}\text { " } \mathrm{CO}_{2}, \quad \text { head- } \\
\text { space" } \\
\text { (ISO 14593) }\end{array}$ & $\begin{array}{l}\text { activated } \\
\text { sludge }\end{array}$ & $15 \mathrm{mg} \mathrm{C} / \mathrm{L}$ & 28 & TOC & [32] \\
\hline 123 & & $\begin{array}{l}\mathrm{R}_{1}=-\mathrm{C}_{6} \mathrm{H}_{13} \\
\mathrm{R}_{2}=- \\
\mathrm{CH}_{2} \mathrm{C}(\mathrm{O}) \mathrm{OC}_{3} \mathrm{H}_{7}\end{array}$ & $\mathrm{C}_{8} \mathrm{H}_{17} \mathrm{OSO}_{3}{ }^{-}$ & 15 & $\begin{array}{l}\text { not readily } \\
\text { biodegradable }\end{array}$ & $\begin{array}{l}\text { " } \mathrm{CO}_{2}, \quad \text { head- } \\
\text { space" } \\
\text { (ISO 14593) }\end{array}$ & $\begin{array}{l}\text { activated } \\
\text { sludge }\end{array}$ & $15 \mathrm{mg} \mathrm{C} / \mathrm{L}$ & 28 & TOC & [32] \\
\hline 124 & & $\begin{array}{l}\mathrm{R}_{1}=-\mathrm{C}_{6} \mathrm{H}_{13} \\
\mathrm{R}_{2}=- \\
\mathrm{CH}_{2} \mathrm{C}(\mathrm{O}) \mathrm{OC}_{3} \mathrm{H}_{7}\end{array}$ & $\left(\mathrm{CF}_{3} \mathrm{SO}_{2}\right)_{2} \mathrm{~N}^{-}$ & 0 & $\begin{array}{l}\text { not readily } \\
\text { biodegradable }\end{array}$ & $\begin{array}{l}\text { "CO } \mathrm{CO}_{2} \quad \text { head- } \\
\text { space" } \quad \text { Test } \\
\text { (ISO 14593) }\end{array}$ & $\begin{array}{l}\text { activated } \\
\text { sludge }\end{array}$ & $15 \mathrm{mg} \mathrm{C} / \mathrm{L}$ & 28 & TOC & [32] \\
\hline 125 & & $\begin{array}{l}\mathrm{R}_{1}=-\mathrm{C}_{6} \mathrm{H}_{13} \\
\mathrm{R}_{2}=- \\
\mathrm{CH}_{2} \mathrm{C}(\mathrm{O}) \mathrm{OC}_{5} \mathrm{H}_{11}\end{array}$ & $\mathrm{Br}^{-}$ & 4 & $\begin{array}{l}\text { not readily } \\
\text { biodegradable }\end{array}$ & $\begin{array}{l}\text { " } \mathrm{CO}_{2}, \quad \text { head- } \\
\text { space" } \\
\text { (ISO 14593) }\end{array}$ & $\begin{array}{l}\text { activated } \\
\text { sludge }\end{array}$ & $15 \mathrm{mg} \mathrm{C} / \mathrm{L}$ & 28 & TOC & [32] \\
\hline 126 & & $\begin{array}{l}\mathrm{R}_{1}=-\mathrm{C}_{6} \mathrm{H}_{13} \\
\mathrm{R}_{2}=- \\
\mathrm{CH}_{2} \mathrm{C}(\mathrm{O}) \mathrm{OC}_{5} \mathrm{H}_{11}\end{array}$ & $\mathrm{C}_{8} \mathrm{H}_{17} \mathrm{OSO}_{3}{ }^{-}$ & 20 & $\begin{array}{l}\text { not readily } \\
\text { biodegradable }\end{array}$ & $\begin{array}{l}\text { " } \mathrm{CO}_{2} \quad \text { head- } \\
\text { space" } \quad \text { Test } \\
\text { (ISO 14593) }\end{array}$ & $\begin{array}{l}\text { activated } \\
\text { sludge }\end{array}$ & $15 \mathrm{mg} \mathrm{C} / \mathrm{L}$ & 28 & TOC & [32] \\
\hline 127 & & $\begin{array}{l}\mathrm{R}_{1}=-\mathrm{C}_{6} \mathrm{H}_{13} \\
\mathrm{R}_{2}=- \\
\mathrm{CH}_{2} \mathrm{C}(\mathrm{O}) \mathrm{OC}_{5} \mathrm{H}_{11}\end{array}$ & $\left(\mathrm{CF}_{3} \mathrm{SO}_{2}\right)_{2} \mathrm{~N}^{-}$ & 2 & $\begin{array}{l}\text { not readily } \\
\text { biodegradable }\end{array}$ & $\begin{array}{l}\text { " } \mathrm{CO}_{2}, \quad \text { head- } \\
\text { space" } \quad \text { Test } \\
\text { (ISO 14593) }\end{array}$ & $\begin{array}{l}\text { activated } \\
\text { sludge }\end{array}$ & $15 \mathrm{mg} \mathrm{C} / \mathrm{L}$ & 28 & TOC & [32] \\
\hline 128 & & $\begin{array}{l}\mathrm{R}_{1}=-\mathrm{C}_{6} \mathrm{H}_{13} \\
\mathrm{R}_{2}=- \\
\mathrm{CH}_{2} \mathrm{C}(\mathrm{O}) \mathrm{OC}_{7} \mathrm{H}_{15}\end{array}$ & $\mathrm{Br}^{-}$ & 10 & $\begin{array}{l}\text { not readily } \\
\text { biodegradable }\end{array}$ & $\begin{array}{l}\text { " } \mathrm{CO}_{2}, \quad \text { head- } \\
\text { space" } \\
\text { (ISO 14593) }\end{array}$ & $\begin{array}{l}\text { activated } \\
\text { sludge }\end{array}$ & $15 \mathrm{mg} \mathrm{C} / \mathrm{L}$ & 28 & TOC & [32] \\
\hline 129 & & $\begin{array}{l}\mathrm{R}_{1}=-\mathrm{C}_{6} \mathrm{H}_{13} \\
\mathrm{R}_{2}=- \\
\mathrm{CH}_{2} \mathrm{C}(\mathrm{O}) \mathrm{OC}_{7} \mathrm{H}_{15}\end{array}$ & $\mathrm{C}_{8} \mathrm{H}_{17} \mathrm{OSO}_{3}^{-}$ & 30 & $\begin{array}{l}\text { not readily } \\
\text { biodegradable }\end{array}$ & $\begin{array}{l}\mathrm{CO}_{2}, \quad \text { head- } \\
\text { space" } \\
\text { (ISO 14593) }\end{array}$ & $\begin{array}{l}\text { activated } \\
\text { sludge }\end{array}$ & $15 \mathrm{mg} \mathrm{C} / \mathrm{L}$ & 28 & TOC & [32] \\
\hline 130 & & $\begin{array}{l}\mathrm{R}_{1}=-\mathrm{C}_{6} \mathrm{H}_{13} \\
\mathrm{R}_{2}=- \\
\mathrm{CH}_{2} \mathrm{C}(\mathrm{O}) \mathrm{OC}_{7} \mathrm{H}_{15}\end{array}$ & $\left(\mathrm{CF}_{3} \mathrm{SO}_{2}\right)_{2} \mathrm{~N}^{-}$ & 0 & $\begin{array}{l}\text { not readily } \\
\text { biodegradable }\end{array}$ & $\begin{array}{l}\text { " } \mathrm{CO}_{2} \text {, head- } \\
\text { space" } \\
\text { (ISO 14593) }\end{array}$ & $\begin{array}{l}\text { activated } \\
\text { sludge }\end{array}$ & $15 \mathrm{mg} \mathrm{C} / \mathrm{L}$ & 28 & TOC & [32] \\
\hline 131 & & $\begin{array}{l}\mathrm{R}_{1}=-\mathrm{C}_{6} \mathrm{H}_{13} \\
\mathrm{R}_{2}=- \\
\mathrm{C}_{4} \mathrm{H}_{8} \mathrm{OC}(\mathrm{O}) \mathrm{CH}_{3}\end{array}$ & $\mathrm{I}^{-}$ & 0 & $\begin{array}{l}\text { not readily } \\
\text { biodegradable }\end{array}$ & $\begin{array}{l}\text { "CO } \mathrm{CO}_{2} \text { head- } \\
\text { space" Test } \\
\text { (ISO 14593) }\end{array}$ & $\begin{array}{l}\text { activated } \\
\text { sludge }\end{array}$ & $15 \mathrm{mg} \mathrm{C} / \mathrm{L}$ & 28 & TOC & [32] \\
\hline 132 & & $\begin{array}{l}\mathrm{R}_{1}=-\mathrm{C}_{6} \mathrm{H}_{13} \\
\mathrm{R}_{2}=- \\
\mathrm{C}_{4} \mathrm{H}_{8} \mathrm{OC}(\mathrm{O}) \mathrm{CH}_{3}\end{array}$ & $\mathrm{C}_{8} \mathrm{H}_{17} \mathrm{OSO}_{3}{ }^{-}$ & 5 & $\begin{array}{l}\text { not readily } \\
\text { biodegradable }\end{array}$ & $\begin{array}{l}\text { " } \mathrm{CO}_{2}, \quad \text { head- } \\
\text { space" } \\
\text { (ISO 14593) }\end{array}$ & $\begin{array}{l}\text { activated } \\
\text { sludge }\end{array}$ & $15 \mathrm{mg} \mathrm{C} / \mathrm{L}$ & 28 & TOC & [32] \\
\hline
\end{tabular}




\begin{tabular}{|c|c|c|c|c|c|c|c|c|c|c|}
\hline 133 & $\begin{array}{l}\mathrm{R}_{1}=-\mathrm{C}_{6} \mathrm{H}_{13} \\
\mathrm{R}_{2}=- \\
\mathrm{C}_{4} \mathrm{H}_{8} \mathrm{OC}(\mathrm{O}) \mathrm{CH}_{3}\end{array}$ & $\left(\mathrm{CF}_{3} \mathrm{SO}_{2}\right)_{2} \mathrm{~N}^{-}$ & 0 & $\begin{array}{l}\text { not readily } \\
\text { biodegradable }\end{array}$ & $\begin{array}{l}\text { " } \mathrm{CO}_{2}, \quad \text { head- } \\
\text { space" } \quad \text { Test } \\
\text { (ISO 14593) }\end{array}$ & $\begin{array}{l}\text { activated } \\
\text { sludge }\end{array}$ & $15 \mathrm{mg} \mathrm{C} / \mathrm{L}$ & 28 & TOC & [32] \\
\hline 134 & $\begin{array}{l}\mathrm{R}_{1}=-\mathrm{C}_{6} \mathrm{H}_{13} \\
\mathrm{R}_{2}=-\mathrm{CH}_{2} \mathrm{CH}=\mathrm{CH}_{2}\end{array}$ & $\mathrm{Br}$ & 8 & $\begin{array}{l}\text { not readily } \\
\text { biodegradable }\end{array}$ & $\begin{array}{l}\text { " } \mathrm{CO}_{2}, \quad \text { head- } \\
\text { space" } \quad \text { Test } \\
\text { (ISO 14593) }\end{array}$ & $\begin{array}{l}\text { activated } \\
\text { sludge }\end{array}$ & $15 \mathrm{mg} \mathrm{C} / \mathrm{L}$ & 28 & TOC & [32] \\
\hline 135 & $\begin{array}{l}\mathrm{R}_{1}=-\mathrm{C}_{6} \mathrm{H}_{13} \\
\mathrm{R}_{2}=-\mathrm{CH}_{2} \mathrm{CH}=\mathrm{CH}_{2}\end{array}$ & $\mathrm{C}_{8} \mathrm{H}_{17} \mathrm{OSO}_{3}^{-}$ & 18 & $\begin{array}{l}\text { not readily } \\
\text { biodegradable }\end{array}$ & $\begin{array}{l}\text { " } \mathrm{CO}_{2} \text {, head- } \\
\text { space" } \\
\text { (ISO 14593) }\end{array}$ & $\begin{array}{l}\text { activated } \\
\text { sludge }\end{array}$ & $15 \mathrm{mg} \mathrm{C} / \mathrm{L}$ & 28 & TOC & [32] \\
\hline 136 & $\begin{array}{l}\mathrm{R}_{1}=-\mathrm{C}_{6} \mathrm{H}_{13} \\
\mathrm{R}_{2}=-\mathrm{CH}_{2} \mathrm{CH}=\mathrm{CH}_{2}\end{array}$ & $\left(\mathrm{CF}_{3} \mathrm{SO}_{2}\right)_{2} \mathrm{~N}^{-}$ & 0 & $\begin{array}{l}\text { not readily } \\
\text { biodegradable }\end{array}$ & $\begin{array}{l}\text { " } \mathrm{CO}_{2} \quad \text { head- } \\
\text { space" } \quad \text { Test } \\
\text { (ISO 14593) }\end{array}$ & $\begin{array}{l}\text { activated } \\
\text { sludge }\end{array}$ & $15 \mathrm{mg} \mathrm{C} / \mathrm{L}$ & 28 & TOC & [32] \\
\hline 137 & $\begin{array}{l}\mathrm{R}_{1}=-\mathrm{C}_{6} \mathrm{H}_{13} \\
\mathrm{R}_{2}=-\mathrm{CH}_{2} \mathrm{OCH}_{3}\end{array}$ & $\mathrm{Cl}^{-}$ & 2 & $\begin{array}{l}\text { not readily } \\
\text { biodegradable }\end{array}$ & $\begin{array}{l}\text { " } \mathrm{CO}_{2}, \quad \text { head- } \\
\text { space" } \quad \text { Test } \\
\text { (ISO 14593) }\end{array}$ & $\begin{array}{l}\text { activated } \\
\text { sludge }\end{array}$ & $15 \mathrm{mg} \mathrm{C} / \mathrm{L}$ & 28 & TOC & [32] \\
\hline 138 & $\begin{array}{l}\mathrm{R}_{1}=-\mathrm{C}_{6} \mathrm{H}_{13} \\
\mathrm{R}_{2}=-\mathrm{CH}_{2} \mathrm{OCH}_{3}\end{array}$ & $\mathrm{C}_{8} \mathrm{H}_{17} \mathrm{OSO}_{3}{ }^{-}$ & 11 & $\begin{array}{l}\text { not readily } \\
\text { biodegradable }\end{array}$ & $\begin{array}{l}\text { " } \mathrm{CO}_{2}, \quad \text { head- } \\
\text { space" Test } \\
\text { (ISO 14593) }\end{array}$ & $\begin{array}{l}\text { activated } \\
\text { sludge }\end{array}$ & $15 \mathrm{mg} \mathrm{C} / \mathrm{L}$ & 28 & TOC & [32] \\
\hline 139 & $\begin{array}{l}\mathrm{R}_{1}=-\mathrm{C}_{6} \mathrm{H}_{13} \\
\mathrm{R}_{2}=-\mathrm{CH}_{2} \mathrm{OCH}_{3}\end{array}$ & $\left(\mathrm{CF}_{3} \mathrm{SO}_{2}\right)_{2} \mathrm{~N}^{-}$ & 0 & $\begin{array}{l}\text { not readily } \\
\text { biodegradable }\end{array}$ & $\begin{array}{l}\text { " } \mathrm{CO}_{2}, \quad \text { head- } \\
\text { space" Test } \\
\text { (ISO 14593) }\end{array}$ & $\begin{array}{l}\text { activated } \\
\text { sludge }\end{array}$ & $15 \mathrm{mg} \mathrm{C} / \mathrm{L}$ & 28 & TOC & [32] \\
\hline 140 & $\begin{array}{l}\mathrm{R}_{1}=-\mathrm{C}_{6} \mathrm{H}_{13} \\
\mathrm{R}_{2}=-\mathrm{C}_{2} \mathrm{H}_{4} \mathrm{OH}\end{array}$ & $\mathrm{Br}$ & 0 & $\begin{array}{l}\text { not readily } \\
\text { biodegradable }\end{array}$ & $\begin{array}{l}\text { " } \mathrm{CO}_{2} \quad \text { head- } \\
\text { space" } \quad \text { Test } \\
\text { (ISO 14593) }\end{array}$ & $\begin{array}{l}\text { activated } \\
\text { sludge }\end{array}$ & $15 \mathrm{mg} \mathrm{C} / \mathrm{L}$ & 28 & TOC & [32] \\
\hline 141 & $\begin{array}{l}\mathrm{R}_{1}=-\mathrm{C}_{6} \mathrm{H}_{13} \\
\mathrm{R}_{2}=-\mathrm{C}_{2} \mathrm{H}_{4} \mathrm{OH}\end{array}$ & $\mathrm{C}_{8} \mathrm{H}_{17} \mathrm{OSO}_{3}^{-}$ & 9 & $\begin{array}{l}\text { not readily } \\
\text { biodegradable }\end{array}$ & $\begin{array}{l}" \mathrm{CO}_{2}, \quad \text { head- } \\
\text { space" Test } \\
\text { (ISO 14593) }\end{array}$ & $\begin{array}{l}\text { activated } \\
\text { sludge }\end{array}$ & $15 \mathrm{mg} \mathrm{C} / \mathrm{L}$ & 28 & TOC & [32] \\
\hline 142 & $\begin{array}{l}\mathrm{R}_{1}=-\mathrm{C}_{6} \mathrm{H}_{13} \\
\mathrm{R}_{2}=-\mathrm{C}_{2} \mathrm{H}_{4} \mathrm{OH}\end{array}$ & $\left(\mathrm{CF}_{3} \mathrm{SO}_{2}\right)_{2} \mathrm{~N}^{-}$ & 0 & $\begin{array}{l}\text { not readily } \\
\text { biodegradable }\end{array}$ & $\begin{array}{l}\text { " } \mathrm{CO}_{2} \quad \text { head- } \\
\text { space" } \quad \text { Test } \\
\text { (ISO 14593) }\end{array}$ & $\begin{array}{l}\text { activated } \\
\text { sludge }\end{array}$ & $15 \mathrm{mg} \mathrm{C} / \mathrm{L}$ & 28 & TOC & [32] \\
\hline $143 \mathrm{a}$ & $\begin{array}{l}\mathrm{R}_{1}=- \text { cyclohexyl } \\
\mathrm{R}_{2}=- \\
\mathrm{CH}_{2} \mathrm{C}(\mathrm{O}) \mathrm{OC}_{3} \mathrm{H}_{7}\end{array}$ & $\mathrm{Br}^{-}$ & 7 & $\begin{array}{l}\text { not readily } \\
\text { biodegradable }\end{array}$ & $\begin{array}{l}\text { " } \mathrm{CO}_{2}, \quad \text { head- } \\
\text { space" } \quad \text { Test } \\
\text { (ISO 14593) }\end{array}$ & $\begin{array}{l}\text { activated } \\
\text { sludge }\end{array}$ & $10 \mathrm{mg} \mathrm{C} / \mathrm{L}$ & 28 & TOC & [32] \\
\hline $143 b$ & $\begin{array}{l}\mathrm{R}_{1}=- \text { cyclohexyl } \\
\mathrm{R}_{2}=- \\
\mathrm{CH}_{2} \mathrm{C}(\mathrm{O}) \mathrm{OC}_{3} \mathrm{H}_{7}\end{array}$ & $\mathrm{Br}^{-}$ & 4 & $\begin{array}{l}\text { not readily } \\
\text { biodegradable }\end{array}$ & $\begin{array}{l}\text { " } \mathrm{CO}_{2}, \quad \text { head- } \\
\text { space" } \quad \text { Test } \\
\text { (ISO 14593) }\end{array}$ & $\begin{array}{l}\text { activated } \\
\text { sludge }\end{array}$ & $20 \mathrm{mg} \mathrm{C} / \mathrm{L}$ & 28 & TOC & [32] \\
\hline $144 \mathrm{a}$ & $\begin{array}{l}\mathrm{R}_{1}=- \text { cyclohexyl } \\
\mathrm{R}_{2}=- \\
\mathrm{CH}_{2} \mathrm{C}(\mathrm{O}) \mathrm{OC}_{3} \mathrm{H}_{7}\end{array}$ & $\mathrm{C}_{8} \mathrm{H}_{17} \mathrm{OSO}_{3}^{-}$ & 23 & $\begin{array}{l}\text { not readily } \\
\text { biodegradable }\end{array}$ & $\begin{array}{l}\text { " } \mathrm{CO}_{2}, \quad \text { head- } \\
\text { space" } \quad \text { Test } \\
\text { (ISO 14593) }\end{array}$ & $\begin{array}{l}\text { activated } \\
\text { sludge }\end{array}$ & $10 \mathrm{mg} \mathrm{C} / \mathrm{L}$ & 28 & TOC & [32] \\
\hline $144 b$ & $\begin{array}{l}\mathrm{R}_{1}=- \text { cyclohexyl } \\
\mathrm{R}_{2}=- \\
\mathrm{CH}_{2} \mathrm{C}(\mathrm{O}) \mathrm{OC}_{3} \mathrm{H}_{7}\end{array}$ & $\mathrm{C}_{8} \mathrm{H}_{17} \mathrm{OSO}_{3}^{-}$ & 18 & $\begin{array}{l}\text { not readily } \\
\text { biodegradable }\end{array}$ & $\begin{array}{l}\text { " } \mathrm{CO}_{2}, \quad \text { head- } \\
\text { space" Test } \\
\text { (ISO 14593) }\end{array}$ & $\begin{array}{l}\text { activated } \\
\text { sludge }\end{array}$ & $20 \mathrm{mg} \mathrm{C} / \mathrm{L}$ & 28 & TOC & [32] \\
\hline 145 & $\begin{array}{l}\mathrm{R}_{1}=- \text { cyclohexyl } \\
\mathrm{R}_{2}=- \\
\mathrm{CH}_{2} \mathrm{C}(\mathrm{O}) \mathrm{OC}_{3} \mathrm{H}_{7}\end{array}$ & $\left(\mathrm{CF}_{3} \mathrm{SO}_{2}\right)_{2} \mathrm{~N}^{-}$ & 7 & $\begin{array}{l}\text { not readily } \\
\text { biodegradable }\end{array}$ & $\begin{array}{l}\text { " } \mathrm{CO}_{2}, \quad \text { head- } \\
\text { space" } \quad \text { Test } \\
\text { (ISO 14593) }\end{array}$ & $\begin{array}{l}\text { activated } \\
\text { sludge }\end{array}$ & $20 \mathrm{mg} \mathrm{C} / \mathrm{L}$ & 28 & TOC & [32] \\
\hline $146 \mathrm{a}$ & $\begin{array}{l}\mathrm{R}_{1}=- \text { cyclohexyl } \\
\mathrm{R}_{2}=- \\
\mathrm{CH}_{2} \mathrm{C}(\mathrm{O}) \mathrm{OC}_{5} \mathrm{H}_{11}\end{array}$ & $\mathrm{Br}$ & 9 & $\begin{array}{l}\text { not readily } \\
\text { biodegradable }\end{array}$ & $\begin{array}{l}\text { " } \mathrm{CO}_{2} \quad \text { head- } \\
\text { space" } \quad \text { Test } \\
\text { (ISO 14593) }\end{array}$ & $\begin{array}{l}\text { activated } \\
\text { sludge }\end{array}$ & $10 \mathrm{mg} \mathrm{C} / \mathrm{L}$ & 28 & TOC & [32] \\
\hline $146 \mathrm{~b}$ & $\begin{array}{l}\mathrm{R}_{1}=- \text { cyclohexyl } \\
\mathrm{R}_{2}=- \\
\mathrm{CH}_{2} \mathrm{C}(\mathrm{O}) \mathrm{OC}_{5} \mathrm{H}_{11}\end{array}$ & $\mathrm{Br}^{-}$ & 3 & $\begin{array}{l}\text { not readily } \\
\text { biodegradable }\end{array}$ & $\begin{array}{l}\text { " } \mathrm{CO}_{2} \quad \text { head- } \\
\text { space" } \quad \text { Test } \\
\text { (ISO 14593) }\end{array}$ & $\begin{array}{l}\text { activated } \\
\text { sludge }\end{array}$ & $20 \mathrm{mg} \mathrm{C} / \mathrm{L}$ & 28 & TOC & [32] \\
\hline 147 & $\begin{array}{l}\mathrm{R}_{1}=- \text { cyclohexyl } \\
\mathrm{R}_{2}=- \\
\mathrm{CH}_{2} \mathrm{C}(\mathrm{O}) \mathrm{OC}_{5} \mathrm{H}_{11}\end{array}$ & $\mathrm{C}_{8} \mathrm{H}_{17} \mathrm{OSO}_{3}^{-}$ & 22 & $\begin{array}{l}\text { not readily } \\
\text { biodegradable }\end{array}$ & $\begin{array}{l}\text { " } \mathrm{CO}_{2}, \quad \text { head- } \\
\text { space" } \quad \text { Test } \\
\text { (ISO 14593) }\end{array}$ & $\begin{array}{l}\text { activated } \\
\text { sludge }\end{array}$ & $20 \mathrm{mg} \mathrm{C} / \mathrm{L}$ & 28 & TOC & [32] \\
\hline 148 & $\begin{array}{l}\mathrm{R}_{1}=- \text { cyclohexyl } \\
\mathrm{R}_{2}=- \\
\mathrm{CH}_{2} \mathrm{C}(\mathrm{O}) \mathrm{OC}_{5} \mathrm{H}_{11}\end{array}$ & $\left(\mathrm{CF}_{3} \mathrm{SO}_{2}\right)_{2} \mathrm{~N}^{-}$ & 2 & $\begin{array}{l}\text { not readily } \\
\text { biodegradable }\end{array}$ & $\begin{array}{l}\text { " } \mathrm{CO}_{2} \quad \text { head- } \\
\text { space" } \quad \text { Test } \\
\text { (ISO 14593) }\end{array}$ & $\begin{array}{l}\text { activated } \\
\text { sludge }\end{array}$ & $20 \mathrm{mg} \mathrm{C} / \mathrm{L}$ & 28 & TOC & [32] \\
\hline $149 \mathrm{a}$ & $\begin{array}{l}\mathrm{R}_{1}=- \text { cyclohexyl } \\
\mathrm{R}_{2}=- \\
\mathrm{CH}_{2} \mathrm{C}(\mathrm{O}) \mathrm{OC}_{7} \mathrm{H}_{15}\end{array}$ & $\mathrm{Br}^{-}$ & 9 & $\begin{array}{l}\text { not readily } \\
\text { biodegradable }\end{array}$ & $\begin{array}{l}{ }^{\prime} \mathrm{CO}_{2} \quad \text { head- } \\
\text { space" } \quad \text { Test } \\
\text { (ISO 14593) }\end{array}$ & $\begin{array}{l}\text { activated } \\
\text { sludge }\end{array}$ & $10 \mathrm{mg} \mathrm{C} / \mathrm{L}$ & 28 & TOC & [32] \\
\hline $149 \mathrm{~b}$ & $\begin{array}{l}\mathrm{R}_{1}=- \text { cyclohexyl } \\
\mathrm{R}_{2}=- \\
\mathrm{CH}_{2} \mathrm{C}(\mathrm{O}) \mathrm{OC}_{7} \mathrm{H}_{15}\end{array}$ & $\mathrm{Br}$ & 2 & $\begin{array}{l}\text { not readily } \\
\text { biodegradable }\end{array}$ & $\begin{array}{l}\text { " } \mathrm{CO}_{2} \quad \text { head- } \\
\text { space" } \quad \text { Test } \\
\text { (ISO 14593) }\end{array}$ & $\begin{array}{l}\text { activated } \\
\text { sludge }\end{array}$ & $20 \mathrm{mg} \mathrm{C} / \mathrm{L}$ & 28 & TOC & [32] \\
\hline $150 \mathrm{a}$ & $\begin{array}{l}\mathrm{R}_{1}=- \text { cyclohexyl } \\
\mathrm{R}_{2}=- \\
\mathrm{CH}_{2} \mathrm{C}(\mathrm{O}) \mathrm{OC}_{7} \mathrm{H}_{15}\end{array}$ & $\mathrm{C}_{8} \mathrm{H}_{17} \mathrm{OSO}_{3}^{-}$ & 27 & $\begin{array}{l}\text { not readily } \\
\text { biodegradable }\end{array}$ & $\begin{array}{l}\text { " } \mathrm{CO}_{2} \quad \text { head- } \\
\text { space" } \quad \text { Test } \\
\text { (ISO 14593) }\end{array}$ & $\begin{array}{l}\text { activated } \\
\text { sludge }\end{array}$ & $10 \mathrm{mg} \mathrm{C} / \mathrm{L}$ & 28 & TOC & [32] \\
\hline $150 \mathrm{~b}$ & $\begin{array}{l}\mathrm{R}_{1}=- \text { cyclohexyl } \\
\mathrm{R}_{2}=- \\
\mathrm{CH}_{2} \mathrm{C}(\mathrm{O}) \mathrm{OC}_{7} \mathrm{H}_{15}\end{array}$ & $\mathrm{C}_{8} \mathrm{H}_{17} \mathrm{OSO}_{3}^{-}$ & 21 & $\begin{array}{l}\text { not readily } \\
\text { biodegradable }\end{array}$ & $\begin{array}{l}\text { " } \mathrm{CO}_{2}, \quad \text { head- } \\
\text { space" } \quad \text { Test } \\
\text { (ISO 14593) }\end{array}$ & $\begin{array}{l}\text { activated } \\
\text { sludge }\end{array}$ & $20 \mathrm{mg} \mathrm{C} / \mathrm{L}$ & 28 & TOC & [32] \\
\hline 151 & $\begin{array}{l}\mathrm{R}_{1}=- \text { cyclohexyl } \\
\mathrm{R}_{2}=- \\
\mathrm{CH}_{2} \mathrm{C}(\mathrm{O}) \mathrm{OC}_{7} \mathrm{H}_{15}\end{array}$ & $\left(\mathrm{CF}_{3} \mathrm{SO}_{2}\right)_{2} \mathrm{~N}^{-}$ & 3 & $\begin{array}{l}\text { not readily } \\
\text { biodegradable }\end{array}$ & $\begin{array}{l}\text { " } \mathrm{CO}_{2}, \quad \text { head- } \\
\text { space" Test } \\
\text { (ISO 14593) }\end{array}$ & $\begin{array}{l}\text { activated } \\
\text { sludge }\end{array}$ & $20 \mathrm{mg} \mathrm{C} / \mathrm{L}$ & 28 & TOC & [32] \\
\hline $152 \mathrm{a}$ & $\begin{array}{l}\mathrm{R}_{1}=- \text { cyclohexyl } \\
\mathrm{R}_{2}=- \\
\mathrm{C}_{4} \mathrm{H}_{8} \mathrm{OC}(\mathrm{O}) \mathrm{OCH}_{3}\end{array}$ & $\mathrm{I}^{-}$ & 10 & $\begin{array}{l}\text { not readily } \\
\text { biodegradable }\end{array}$ & $\begin{array}{l}\text { " } \mathrm{CO}_{2}, \quad \text { head- } \\
\text { space" Test } \\
\text { (ISO 14593) }\end{array}$ & $\begin{array}{l}\text { activated } \\
\text { sludge }\end{array}$ & $10 \mathrm{mg} \mathrm{C} / \mathrm{L}$ & 28 & TOC & [32] \\
\hline $152 \mathrm{~b}$ & $\begin{array}{l}\mathrm{R}_{1}=- \text { cyclohexyl } \\
\mathrm{R}_{2}=- \\
\mathrm{C}_{4} \mathrm{H}_{8} \mathrm{OC}(\mathrm{O}) \mathrm{OCH}_{3}\end{array}$ & $\mathrm{I}^{-}$ & 9 & $\begin{array}{l}\text { not readily } \\
\text { biodegradable }\end{array}$ & $\begin{array}{l}\text { " } \mathrm{CO}_{2} \quad \text { head- } \\
\text { space" } \quad \text { Test } \\
\text { (ISO 14593) }\end{array}$ & $\begin{array}{l}\text { activated } \\
\text { sludge }\end{array}$ & $20 \mathrm{mg} \mathrm{C} / \mathrm{L}$ & 28 & TOC & [32] \\
\hline
\end{tabular}




\begin{tabular}{|c|c|c|c|c|c|c|c|c|c|c|c|}
\hline $153 a$ & & $\begin{array}{l}\mathrm{R}_{1}=- \text { cyclohexyl } \\
\mathrm{R}_{2}=- \\
\mathrm{C}_{4} \mathrm{H}_{8} \mathrm{OC}(\mathrm{O}) \mathrm{OCH}_{3}\end{array}$ & $\mathrm{C}_{8} \mathrm{H}_{17} \mathrm{OSO}_{3}^{-}$ & 25 & $\begin{array}{l}\text { not readily } \\
\text { biodegradable }\end{array}$ & $\begin{array}{l}\text { "CO } \mathrm{CO}_{2} \text { head- } \\
\text { space" Test } \\
\text { (ISO 14593) }\end{array}$ & $\begin{array}{l}\text { activated } \\
\text { sludge }\end{array}$ & $10 \mathrm{mg} \mathrm{C} / \mathrm{L}$ & 28 & TOC & [32] \\
\hline $153 b$ & & $\begin{array}{l}\mathrm{R}_{1}=- \text { cyclohexyl } \\
\mathrm{R}_{2}=- \\
\mathrm{C}_{4} \mathrm{H}_{8} \mathrm{OC}(\mathrm{O}) \mathrm{OCH}_{3}\end{array}$ & $\mathrm{C}_{8} \mathrm{H}_{17} \mathrm{OSO}_{3}{ }^{-}$ & 22 & $\begin{array}{l}\text { not readily } \\
\text { biodegradable }\end{array}$ & $\begin{array}{l}\text { "CO } \mathrm{CO}_{2} \text {, head- } \\
\text { space" } \quad \text { Test } \\
\text { (ISO 14593) }\end{array}$ & $\begin{array}{l}\text { activated } \\
\text { sludge }\end{array}$ & $20 \mathrm{mg} \mathrm{C} / \mathrm{L}$ & 28 & TOC & [32] \\
\hline $154 a$ & & $\begin{array}{l}\mathrm{R}_{1}=- \text { cyclohexyl } \\
\mathrm{R}_{2}=- \\
\mathrm{C}_{4} \mathrm{H}_{8} \mathrm{OC}(\mathrm{O}) \mathrm{OCH}_{3}\end{array}$ & $\left(\mathrm{CF}_{3} \mathrm{SO}_{2}\right)_{2} \mathrm{~N}^{-}$ & 9 & $\begin{array}{l}\text { not readily } \\
\text { biodegradable }\end{array}$ & $\begin{array}{l}\text { " } \mathrm{CO}_{2} \text {, head- } \\
\text { space" Test } \\
\text { (ISO 14593) }\end{array}$ & $\begin{array}{l}\text { activated } \\
\text { sludge }\end{array}$ & $10 \mathrm{mg} \mathrm{C} / \mathrm{L}$ & 28 & TOC & [32] \\
\hline $154 \mathrm{~b}$ & & $\begin{array}{l}\mathrm{R}_{1}=- \text { cyclohexyl } \\
\mathrm{R}_{2}=- \\
\mathrm{C}_{4} \mathrm{H}_{8} \mathrm{OC}(\mathrm{O}) \mathrm{OCH}_{3}\end{array}$ & $\left(\mathrm{CF}_{3} \mathrm{SO}_{2}\right)_{2} \mathrm{~N}^{-}$ & 9 & $\begin{array}{l}\text { not readily } \\
\text { biodegradable }\end{array}$ & $\begin{array}{l}\text { "CO } \mathrm{CO}_{2} \text { head- } \\
\text { space" } \quad \text { Test } \\
\text { (ISO 14593) }\end{array}$ & $\begin{array}{l}\text { activated } \\
\text { sludge }\end{array}$ & $20 \mathrm{mg} \mathrm{C} / \mathrm{L}$ & 28 & TOC & [32] \\
\hline 155 & 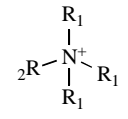 & $\begin{array}{l}\mathrm{R}_{1}=-\mathrm{C}_{8} \mathrm{H}_{17} \\
\mathrm{R}_{2}=-\mathrm{CH}_{3}\end{array}$ & $\left(\mathrm{CF}_{3} \mathrm{SO}_{2}\right)_{2} \mathrm{~N}^{-}$ & 0 & $\begin{array}{l}\text { not readily } \\
\text { biodegradable }\end{array}$ & OECD $301 \mathrm{~F}$ & $\begin{array}{l}\text { not speci- } \\
\text { fied }\end{array}$ & $100 \mathrm{mg} / \mathrm{mL}$ & 28 & $\begin{array}{l}\text { BOD } \\
\text { COD }\end{array}$ & [17] \\
\hline
\end{tabular}

BOD: Biochemical oxygen demand is the amount of oxygen consumed by microorganisms when metabolizing the test chemical. The BOD is expressed in mg oxygen depletion per mg test chemical. TOC: Total organic carbon is the amount of carbon bound in an organic test chemical.

COD: Chemical oxygen demand is the amount of oxygen consumed during the oxidation of a test chemical with hot, acid dichromate. The COD is used to measure indirectly the amount of oxidizable organic matter in solution.

\section{REFERENCES}

[1] Swatloski, R. P.; Spear, S. K.; Holbrey, J. D.; Rogers, R. D. Dissolution of cellose with ionic liquids. Journal of the American Chemical Society 2002, 124 (18), 4974-4975.

[2] Endres, F.; Bukowski, M.; Hempelmann, R.; Natter, H. Electrodeposition of nanocrystalline metals and alloys from ionic liquids. Angewandte ChemieInternational Edition 2003, 42 (29), 3428-3430.

[3] Adler, R. Mobility under high pressure. Linde Technology 2006, January 2006, 24-26.

[4] Tempel D.J.; Henderson, P. B.; Brzozowski, J. R.; Pearlstein, R. M.; Garg, D. Ionic liquid based mixtures for gas storage and delivery. US Pat., 2006060818,2006

[5] Holbrey, J. D.; Plechkova, N. V.; Seddon, K. R. Recalling COIL. Green Chem 2006, 8 (5), 411-414.

[6] Grätzel, M. Dye-sensitized solar cells. Journal of Photochemistry and Photobiology C-Photochemistry Reviews 2003, 4 (2), 145-153.

[7] Weyershausen, B.; Lehmann, K. Industrial application of ionic liquids as performance additives. Green Chem 2005, 7 (1), 15-19.

[8] Plechkova, N. V.; Seddon, K. R. Applications of ionic liquids in the chemical industry. Chemical Society Reviews 2008, 37 (1), 123-150.

[9] Anastas, P. T.; Warner, J. C. Green Chemistry: Theory and Practice; Oxford University Press: New York: 1998.

[10] Arning, J.; Stolte, S.; Böschen, A.; Stock, F.; Pitner, W. R.; Welz-Biermann, U.; Jastorff, B.; Ranke, J. Qualitative and quantitative structure activity relationships for the inhibitory effects of cationic head groups, functionalised side chains and anions of ionic liquids on acetylcholinesterase. Green Chem 2008, 10 (1), 47-58.

[11] Latala, A.; Stepnowski, P.; Nedzi, M.; Mrozik, W. Marine toxicity assessment of imidazolium ionic liquids: Acute effects on the Baltic algae Oocystis submarina and Cyclotella meneghiniana. Aquatic Toxicology 2005, 73 (1), 91-98.

[12] Matzke, M.; Stolte, S.; Thiele, K.; Juffernholz, T.; Arning, J.; Ranke, J.; Welz-Biermann, U.; Jastorff, B. The influence of anion species on the toxicity of 1-alkyl-3-methylimidazolium ionic liquids observed in an (eco) toxicological test battery. Green Chem 2007, 9 (11), 1198-1207.

[13] Ranke, J.; Stolte, S.; Störmann, R.; Arning, J.; Jastorff, B. Design of sustainable chemical products - the example of ionic liquids. Chemical Reviews 2007, 107, 2183-2208.

[14] Stolte, S.; Arning, J.; Bottin-Weber, U.; Müller, A.; Pitner, W. R.; WelzBiermann, U.; Jastorff, B.; Ranke, J. Effects of different head groups and functionalised side chains on the cytotoxicity of ionic liquids. Green Chem 2007, 9 (8), 760-767.

[15] Stolte, S.; Arning, J; Bottin-Weber, U; Matzke, M.; Stock, F; Thiele, K; Uerdingen, M.; Welz-Biermann, U.; Jastorff, B.; Ranke, J. Anion effects on the cytotoxicity of ionic liquids. Green Chem 2006, 8 (7), 621-629.

[16] Stolte, S.; Matzke, M.; Arning, J.; Böschen, A.; Pitner, W. R.; WelzBiermann, U.; Jastorff, B.; Ranke, J. Effects of different head groups and functionalised side chains on the aquatic toxicity of ionic liquids. Green Chem 2007, 9 (11), 1170-1179.

[17] Wells, A. S.; Coombe, V. T. On the freshwater ecotoxicity and biodegradation properties of some common ionic liquids. Organic Process Research and Development 2006, 10 (4), 794-798.

[18] Stolte, S.; Abdulkarim, S.; Arning, J.; Blomeyer-Nienstedt, A.; BottinWeber, U.; Matzke, M.; Jastorff, B.; Thöming, J. Primary biodegradation of ionic liquid cations, identification of degradation products of 1-methyl-3octylimidazolium chloride and electrochemical wastewater treatment of poorly biodegradable compounds. Green Chem 2008, 10 (2), 214-242.

[19] OECD Revised introduction to the OECD guidelines for the testing of chemicals. Section 3 Part 1: Principles and Strategies related to the testing of degradation of organic chemicals; 06.
[20] OECD 301 OECD guideline for testing of chemicals: 301 Ready Biodegradability;Adopted by the Council on 17th July 1992-Ready; 92.

[21] Brown, D. Introduction to surfactant biodegradation. In Biodegradability of Surfactants, Karsa, D. R., Porter, M. R., Eds.; Blackie Academic and Professional: Glasgow, 1995; pp 1-28.

[22] Fewson, C. A. Biodegradation of Xenobiotic and Other Persistent Compounds - the Causes of Recalcitrance. Trends in Biotechnology 1988, 6 (7), 148-153.

[23] Boethling, R. S.; Sommer, E.; DiFiore, D. Designing small molecules for biodegradability. Chemical Reviews 2007, 107 (6), 2207-2227.

[24] Coleman, D.; Gathergood, N. Biodegradation studies of ionic liquids Chemical Society Reviews 2010, 39 (2), 600-637.

[25] Pham, T. P.; Cho, C. W.; Yun, Y. S. Environmental fate and toxicity of ionic liquids: a review. Water Research 2010, 44 (2), 352-372.

[26] Gathergood, N.; Scammells, P. J. Design and preparation of roomtemperature ionic liquids containing biodegradable side chains. Australian Journal of Chemistry 2002, 55 (9), 557-560.

[27] Gathergood, N.; Garcia, M. T.; Scammells, P. J. Biodegradable ionic liquids: Part I. Concept, preliminary targets and evaluation. Green Chem 2004, 6 (2), 166-175.

[28] Garcia, M. T.; Gathergood, N.; Scammells, P. J. Biodegradable ionic liquids - Part II. Effect of the anion and toxicology. Green Chem 2005, 7 (1), 9-14

[29] Gathergood, N.; Scammells, P. J.; Garcia, M. T. Biodegradable ionic liquids - Part III. The first readily biodegradable ionic liquids. Green Chem 2006, 8 (2), 156-160.

[30] Harjani, J. R.; Singer, R. D.; Garcia, M. T.; Scammells, P. J. The design and synthesis of biodegradable pyridinium ionic liquids. Green Chem 2008, 10 (4), 436-438.

[31] Harjani, J. R.; Farrell, J.; Garcia, M. T.; Singer, R. D.; Scammells, P. J. Further investigation of the biodegradability of imidazolium ionic liquids. Green Chem 2009, 11 (6), 821-829.

[32] Atefi, F.; Garcia, M. T.; Singer, R. D.; Scammells, P. J. Phosphonium ionic liquids: design, synthesis and evaluation of biodegradability. Green Chem 2009, 11 (10), 1595-1604

[33] Morrissey, S.; Pegot, B.; Coleman, D.; Garcia, M. T.; Ferguson, D.; Quilty, B.; Gathergood, N. Biodegradable, non-bactericidal oxygen-functionalised imidazolium esters: A step towards 'greener' ionic liquids. Green Chem $\mathbf{2 0 0 9}$, 11 (4), 475-483.

[34] Docherty, K. M.; Dixon, J. K.; Kulpa, C. F. Biodegradability of Imidazolium and Pyridinium Ionic Liquids by an Activated Sludge Microbial Community. Biodegradation 2007, 18, 481-493.

[35] Docherty, K. M.; Joyce M.V.; Kulacki, K. J.; Kulpa, C. F. Microbial biodegradation and metabolite toxicity of three pyridiniumbased cation ionic liquids. Green Chem 2010, DOI: 10.1039/b919154b.

[36] Pham, T. P. T.; Cho, C. W.; Jeon, C. O.; Chung, Y. J.; Lee, M. W.; Yun, Y. $\mathrm{S}$. Identification of Metabolites Involved in the Biodegradation of the Ionic Liquid 1-Butyl-3-methylpyridinium Bromide by Activated Sludge Microorganisms. Environmental Science \& Technology 2009, 43 (2), 516-521.

[37] Zhang, C.; Wang, H.; Malhotra S.V.; Dodge C.J.; Francis, A. J. Biodegradation of pyridiniumbased ionic liquids by an axenic culture of soil Corynebacteria. Green Chem 2010, DOI: 10.1039/b924264c.

[38] Stasiewicz, M.; Mulkiwicz, E.; Tomaczak-Wanzel, R.; Kumirska, J.; Siedlecka, E. M.; Golebiowski, M.; Gajdus, J.; Czerwicka, M.; Stepnowski, P. Assessing toxicity and biodegradation of novel, environmentally benign ionic liquids (1-alkoxymethyl-3-hydroxypyridinium chloride, saccharinate and acesulfamates) on cellular and molecular level. Ecotoxicology and Environmental Safety 2007, 71 (1), 157-165.

[39] Modelli, A.; Sali, A.; Galletti, P.; Samori, C. Biodegradation of oxygenated and non-oxygenated imidazolium-based ionic liquids in soil. Chemosphere 2008, $73(8), 1322-1327$. 
[40] Markiewicz, M.; Jungnickel, C.; Markowska, A.; Szczepaniak, U.; Paszkiewicz, M.; Hupka, J. 1-Methyl-3-octylimidazolium Chloride-Sorption and Primary Biodegradation Analysis in Activated Sewage Sludge. Molecules 2009, 14 (11), 4396-4405.

[41] Stolte, S. (Eco)toxicity and biodegradation of ionic liquids - progress in designing inherently safer chemicals. BATIL-2 (Biodegradability and Toxicity of Ionic Liquids), 29.09.2009.

[42] Painter, H. A. Detergents. In The Handbook of Environmental Chemistry, Springer: Berlin, 2008; pp 1-88

[43] Schleheck, D.; Cook, A. M. Saccharin as a sole source of carbon and energy for Sphingomonas xenophaga SKN. Arch. Microbiol. 2003, 179 (3), 191196.

[44] Vijayaraghavan, R.; Thompson, B. C.; MacFarlane, D. R.; Kumar, R.; Surianarayanan, M.; Aishwarya, S.; Sehgal, P. K. Biocompatibility of choline salts as crosslinking agents for collagen based biomaterials. Chemical Communications 2010, 46 (2), 294-296.

[45] Fukaya, Y.; Iizuka, Y.; Sekikawa, K.; Ohno, H. Bio ionic liquids: room temperature ionic liquids composed wholly of biomaterials. Green Chem 2007, 9 (11), 1155-1157.

[46] Alexander, M. Biodegradation and bioremediation; Academic Press: San Diego, 1994.

[47] U.S.Geological Survey Summary of research results on bacterial degradation of trifluoroacetate (TFA); SuDoc I 19.76 ed.; 1994

[48] Silvaavalos, J; Richmond, M. G.; Nagappan, O.; Kunz, D. A. Degradation of the Metal-Cyano Complex Tetracyanonickelate(Ii) by Cyanide-Utilizing Bacterial Isolates. Applied and Environmental Microbiology 1990, 56 (12), 3664-3670.

[49] Matzke, M.; Stolte, S.; Böschen, A.; Filser, J. Mixture effects and predictability of combination effects of imidazolium based ionic liquids as well as imidazolium based ionic liquids and cadmium on terrestrial plants (Triticum aestivum) and limnic green algae (Scenedesmus vacuolatus). Green Chem. 2008, 10 (7), 784-792.

[50] Rorije, E.; Germa, F.; Philipp, B.; Schink, B.; Beimborn, D. B. Prediction of biodegradability from structure: Imidazoles. Sar and Qsar in Environmental Research 2002, 13 (1), 199-204.

[51] Philipp, B.; Hoff, M.; Germa, F.; Schink, B.; Beimborn, D.; MerschSundermann, V. Biochemical interpretation of quantitative structure-activity relationships (QSAR) for biodegradation of N-heterocycles: A complementary approach to predict biodegradability. Environ. Sci. Technol. 2007, 41 (4), 1390-1398.

[52] Lucak, J.; Jungnickel, C.; Lacka, I.; Stolte, S.; Hupka, J. Antimicrobial and surface activity of 1-alkyl-3-methylimidazolium derivatives. Green Chem 2010, DOI: $10.1039 / 6921805 j$.

[53] Pernak, J.; Sobaszkiewicz, K.; Mirska, I. Anti-microbial activities of ionic liquids. Green Chem. 2003, 5 (1), 52-56.

[54] Visser, A. E.; Swatloski, R. P.; Reichert, W. M.; Mayton, R.; Sheff, S.; Wierzbicki, A.; Davis, J. H.; Rogers, R. D. Task-specific ionic liquids for the extraction of metal ions from aqueous solutions. Chemical Communications 2001, (01), 135-136.
[55] Wasserscheid, P; Driessen-Holscher, B ; van Hal, R ; Steffens, H. C ; Zim mermann, J. New, functionalised ionic liquids from Michael-type reactions a chance for combinatorial ionic liquid development. Chemical Communications 2003, (16), 2038-2039.

[56] O'Loughlin, E. J.; Sims, G. K.; Traina, S. J. Biodegradation of 2-methyl, 2 ethyl, and 2-hydroxypyridine by an Arthrobacter sp isolated from subsurface sediment. Biodegradation 1999, 10 (2), 93-104.

[57] Uma, B.; Sandhya, S. Kinetics of pyridine degradation along with toluene and methylene chloride with Bacillus sp. in packed bed reactor. Bioprocess Engineering 1998, 18 (4), 303-305.

[58] Van Ginkel, C. G. Biodegradability of cationic surfactants. In Biodegradability of Surfactants, Karsa, D. R., Porter, M. R., Eds.; Blackie Academic and Professional: Glasgow, 1995; pp 1-28.

[59] Jastorff, B.; Störmann, R.; Ranke, J. Thinking in structure-activity relationships - a way forward towards sustainable chemistry. Clean-Soil Air Water 2007, 35 (5), 399-405.

[60] Jastorff, B.; Störmann, R.; Ranke, J.; Mölter, K.; Stock, F.; Oberheitmann, B; Hoffmann, W; Hoffmann, J; Nüchter, M.; Ondruschka, B; Filser, J. How hazardous are ionic liquids? Structure-activity relationships and biological testing as important elements for sustainability evaluation. Green Chem 2003, 5 (2), 136-142.

[61] Jastorff, B.; Mölter, K.; Behrend, P.; Bottin-Weber, U.; Filser, J.; Heimers, A.; Ondruschka, B.; Ranke, J.; Schaefer, M.; Schröder, H.; Stark, A.; Stepnowski, P.; Stock, F.; Störmann, R.; Stolte, S.; Welz-Biermann, U.; Ziegert, S.; Thöming, J. Progress in evaluation of risk potential of ionic liquids-basis for an eco-design of sustainable products. Green Chem 2005, 7, 362-372.

[62] Hwu, C. S.; Lu, C. J. Continuous dechlorination of tetrachloroethene in an upflow anaerobic sludge blanket reactor. Biotechnology Letters 2008, 30 (9), 1589-1593.

[63] Master, E. R.; Lai, V. W. M.; Kuipers, B.; Cullen, W. R.; Mohn, W. W. Sequential anaerobic-aerobic treatment of soil contaminated with weathered aroclor 1260. Environmental Science \& Technology 2002, 36 (1), 100-103.

[64] Neumann, J.; Grundmann, O.; Thöming, J.; Schulte, M.; Stolte, S. Anaerobic biodegradability of ionic liquid cations under denitrifying conditions. Green Chem 2010, 20 (4), 620-627.

[65] Baker, G. A.; Baker, S. N. A simple colorimetric assay of ionic liquid hydrolytic stability. Aust. J. Chem. 2005, 58 (3), 174-177.

[66] Villagran, C.; Deetlefs, M.; Pitner, W. R.; Hardacre, C. Quantification of halide in ionic liquids using ion chromatography. Anal. Chem. 2004, 76 (7), 2118-2123.

[67] Smith, F. A. Fluoride Toxicity. In Handbook of Hazardous materials, Academic Press, San Diego: 1993; pp 277-283.

[68] Fernández, J. F.; Waterkamp, D.; Thöming, J. Recovery of Ionic Liquids from Wastewater: Aggregation Control for Intesified Membrane Filtration. Desalination 2008, 224, 52-56.

[69] Stepnowski, P.; Zaleska, A. Comparison of different advanced oxidation processes for degradation of room temperature ionic liquids. Photochem. Photobiol. 2005, 170, 45-50. 